University of South Florida

DIGITAL COMMONS Digital Commons @ University of @ UNIVERSITY OF SOUTH FLORIDA South Florida

5-1-2013

\title{
Effectively Managing Consumer Fuel Price Driven Transit Demand
}

CUTR

Follow this and additional works at: https://digitalcommons.usf.edu/cutr_nctr

\section{Recommended Citation}

"Effectively Managing Consumer Fuel Price Driven Transit Demand," National Center for Transit Research (NCTR) Report No. CUTR-NCTR-RR-2012-05, Center for Urban Transportation Research, University of South Florida, 2013.

DOI: https://doi.org/10.5038/CUTR-NCTR-RR-2012-05

Available at: https://scholarcommons.usf.edu/cutr_nctr/103

This Technical Report is brought to you for free and open access by the National Center for Transit Research (NCTR) Archive (2000-2020) at Digital Commons @ University of South Florida. It has been accepted for inclusion in Research Reports by an authorized administrator of Digital Commons @ University of South Florida. For more information, please contact digitalcommons@usf.edu. 

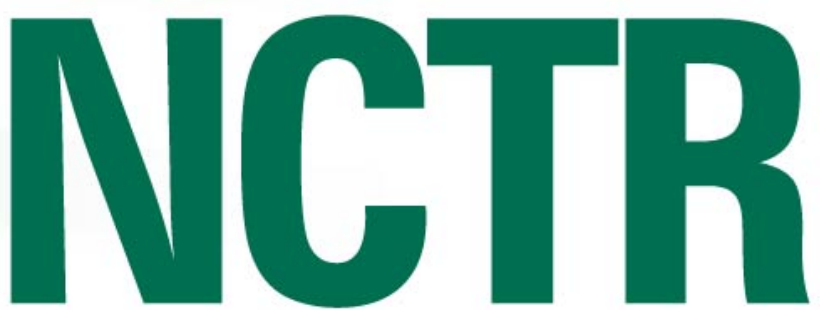

NATIONAL CENTER for TRANSIT RESEARCH

\title{
Effectively Managing Consumer Fuel Price Driven Transit Demand
}

\author{
May 2013
}

PROJECT NO.

FDOT BDK85 Task Work Order \#977-39

PREPARED FOR

Florida Department of Transportation

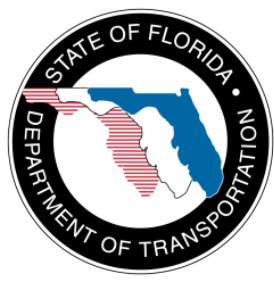




\title{
Effectively Managing Consumer Fuel Price Driven Transit Demand
}

\author{
FDOT BDK85 Task Work Order \#977-39
}

Prepared for:

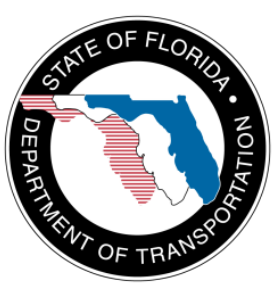

Florida Department of Transportation

Erin Schepers, Project Manager

Prepared by:

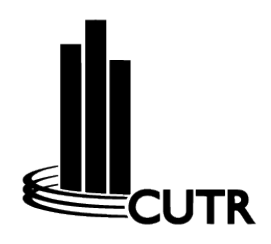

USF Center for Urban Transportation Research

Justin T. Begley, Senior Research Associate

Final Report

May 2013 


\section{Disclaimer}

The contents of this report reflect the views of the authors, who are responsible for the facts and the accuracy of the information presented herein. This document is disseminated under the sponsorship of the U.S. Department of Transportation (USDOT) University Transportation Centers Program and the Florida Department of Transportation (FDOT) in the interest of information exchange. The U.S. Government and the Florida Department of Transportation assume no liability for the contents or use thereof. 


\section{Metric Conversion}

\begin{tabular}{|l|l|l}
\hline SYMBOL & WHEN YOU KNOW & MULTIPLY BY
\end{tabular}

TO FIND

SYMBOL

\section{LENGTH}

\begin{tabular}{|c|c|c|c|c|}
\hline in & inches & 25.4 & millimeters & $\mathrm{mm}$ \\
\hline ft & feet & 0.305 & meters & $\mathrm{m}$ \\
\hline yd & yards & 0.914 & meters & $\mathrm{m}$ \\
\hline mi & miles & 1.61 & kilometers & $\mathrm{km}$ \\
\hline \multicolumn{5}{|c|}{ VOLUME } \\
\hline fl oz & fluid ounces & 29.57 & milliliters & $\mathrm{mL}$ \\
\hline gal & gallons & 3.785 & liters & L \\
\hline $\mathrm{ft}^{3}$ & cubic feet & 0.028 & cubic meters & $\mathrm{m}^{3}$ \\
\hline$y d^{3}$ & cubic yards & 0.765 & cubic meters & $\mathrm{m}^{3}$ \\
\hline \multicolumn{5}{|c|}{ NOTE: volumes greater than $1000 \mathrm{~L}$ shall be shown in $\mathrm{m}^{3}$} \\
\hline \multicolumn{5}{|c|}{ MASS } \\
\hline $\mathbf{o z}$ & ounces & 28.35 & grams & g \\
\hline lb & pounds & 0.454 & kilograms & $\mathrm{kg}$ \\
\hline $\mathbf{T}$ & short tons (2000 lb) & 0.907 & $\begin{array}{c}\text { megagrams } \\
\text { (or "metric ton") }\end{array}$ & Mg (or "t") \\
\hline \multicolumn{5}{|c|}{ TEMPERATURE (exact degrees) } \\
\hline${ }^{\mathbf{O}} \mathbf{F}$ & Fahrenheit & $\begin{array}{c}5(F-32) / 9 \\
\text { or }(F-32) / 1.8\end{array}$ & Celsius & ${ }^{\circ} \mathrm{C}$ \\
\hline
\end{tabular}




\section{Technical Report Documentation}

\begin{tabular}{|c|c|c|c|}
\hline $\begin{array}{l}\text { 1. Report No. } \\
\text { BDK85 977-39 }\end{array}$ & \multicolumn{2}{|c|}{ 2. Government Accession No. } & 3. Recipient's Catalog No. \\
\hline \multicolumn{2}{|l|}{ 4. Title and Subtitle } & \multicolumn{2}{|l|}{ 5. Report Date } \\
\hline \multicolumn{2}{|c|}{$\begin{array}{l}\text { Effectively Managing Consumer Fuel Price Driven Transit } \\
\text { Demand }\end{array}$} & \multicolumn{2}{|l|}{ May 2013} \\
\hline \multicolumn{4}{|c|}{ 6. Performing Organization Code } \\
\hline \multicolumn{2}{|l|}{ Justin T. Begley } & \multicolumn{2}{|c|}{$\begin{array}{l}\text { NCTR 77944/BDK85 977-39 } \\
\text { U.S.DOT DTRS98-G-0032 }\end{array}$} \\
\hline \multicolumn{2}{|c|}{$\begin{array}{l}\text { National Center for Transit Research, } \\
\text { Center for Urban Transportation Research (CUTR) } \\
\text { University of South Florida } \\
4202 \text { East Fowler Ave, CUT 100, Tampa, FL 33620-5375 }\end{array}$} & 10. Work Unit Nc & RAIS) \\
\hline \multicolumn{4}{|c|}{ 11. Contract or Grant No. } \\
\hline \multicolumn{2}{|c|}{$\begin{array}{l}\text { Florida Department of Transpor } \\
\text { Research Center } \\
605 \text { Suwannee Street, MS } 30 \\
\text { Tallahassee, FL 32399-0450 }\end{array}$} & \multicolumn{2}{|c|}{ Final $1 / 31 / 12-5 / 31 / 13$} \\
\hline \multicolumn{2}{|c|}{$\begin{array}{l}\text { Research and Innovative Technology Administration } \\
\text { U.S. Department of Transportation } \\
\text { Mail Code RDT-30, } 1200 \text { New Jersey Ave SE, Room E33 } \\
\text { Washington, DC 20590-0001 }\end{array}$} & & \\
\hline \multicolumn{4}{|c|}{ 14. Sponsoring Agency Code } \\
\hline \multicolumn{4}{|c|}{$\begin{array}{l}\text { 15. Supplementary Notes } \\
\text { Supported by a grant from the Florida Department of Transportation (FDOT) and the U.S. Department of } \\
\text { Transportation (USDOT) }\end{array}$} \\
\hline \multicolumn{4}{|c|}{$\begin{array}{l}\text { This study presents a literature review of transit demand elasticities with respect to gas prices, describes features of a } \\
\text { transit service area population that may be more sensitive to fuel prices, identifies where stress points in the family of } \\
\text { transit services will emerge, and assembles short- and long-term strategies for transit providers to manage their } \\
\text { service when there is volatility in fuel prices. }\end{array}$} \\
\hline \multicolumn{2}{|l|}{ 17. Key Words } & \multicolumn{2}{|c|}{ 18. Distribution Statement } \\
\hline \multicolumn{2}{|c|}{$\begin{array}{l}\text { Effectively managing fuel price, Consumer Fuel Price, Transit } \\
\text { Demand }\end{array}$} & \multicolumn{2}{|c|}{$\begin{array}{l}\text { Available to the public through the National } \\
\text { Technical Information Service (NTIS), } 5285 \text { Port } \\
\text { Royal Road, Springfield, VA 22161(703) } 487-4650 \text {, } \\
\text { http://ntis.gov, and through the NCTR website at } \\
\text { http://www.nctr.usf.edu }\end{array}$} \\
\hline $\begin{array}{l}\text { 19. Security Classification } \\
\text { (of this report) } \\
\text { Unclassified }\end{array}$ & $\begin{array}{l}\text { 20. Security Classification } \\
\text { (of this page) } \\
\text { Unclassified }\end{array}$ & $\begin{array}{l}\text { 21. No. of Pages } \\
90\end{array}$ & \begin{tabular}{l|l} 
22. Price \\
\end{tabular} \\
\hline
\end{tabular}




\section{Acknowledgments}

Many people contributed to this research project, and this final report could not have been completed without their assistance and support. The authors would like to express their gratitude to the Florida Department of Transportation project manager. 


\section{Executive Summary}

While many costs within a household budget have increased in recent years, few have had such an impact as the rise in consumer fuel. The cost of gasoline to operate a personal automobile rose from $\$ 1.55$ per gallon in January 2003 to $\$ 3.40$ in January $2013^{1}$, an increase of $119 \%$. In 2012 , gasoline represented $4 \%$ of pretax household income, the highest percentage in nearly 30 years. ${ }^{2}$ These additional costs may give individuals cause to reevaluate their transportation habits.

Indeed, total vehicle miles traveled (VMT) in the U.S. decreased $4.6 \%$ from its peak in August 2007 to August 2011. ${ }^{3}$ Due in part to a depressed economy and higher unemployment, some previously made trips clearly were not taken. However, it has been demonstrated in several studies that some of these trips may have been instead made on public transportation. Aside from widespread media accounts and other anecdotal observations, research has demonstrated that certain modes of public transportation have seen ridership increases correlated to consumer fuel price increases. This study evaluates that research, describes features of the service area population that may be more sensitive to fuel prices, identifies where stress points in the family of transit services may emerge, and assembles short- and long-term strategies for transit providers to manage volatility in fuel prices.

\section{How Does Travel Behavior Respond When Gas Prices Go Up?}

The primary effect of rising gas prices on driving behavior is fewer total vehicle miles traveled. Aside from trips not taken, travel was shortened, displaced to other modes (including transit) and in part eliminated by trip chaining, or, linking trips that were previously made independently. ${ }^{4}$

Due to the relatively low mode share of transit nationally and the fact that about only half of the U.S. population has access to transit, any increases in public transportation use will represent a small fraction of total travel. Within this small subset of total travel, many studies have identified a statistically significant relationship with respect to transit demand where access was available during times of gas prices increases.

\section{Elasticity of Transit Demand with Respect to Gas Prices}

Elasticity is the measure of a change in one variable (in this case, transit demand) in response to the change in another variable (gas prices). Transit demand elasticities are typically expressed as an expected response to a 1\% change in another variable (see Figure ES-1). Features of the relationship between gas prices and transit demand include:

- Long-term transit elasticities of greater than 12 months are larger than short-term elasticities of 12 months or less.

- Transit demand resulting from gas prices can be lagged in the short term, typically from 1 to 3 months, and lagged until over a year later depending on local circumstances.

- Ridership gained from gas price increases is somewhat 'sticky' in that some amount is retained when gas prices retreat to previous levels. 
- Transit demand is more elastic for riders with other travel options, also called discretionary users. Transit demand is largely inelastic for transit-dependent users. Both demographics and urban setting appear to play a role in how the response to gas prices is shaped.

- Large cities tend to have lower price elasticities than medium-sized cities and suburbs, but respond more quickly to gas price changes.

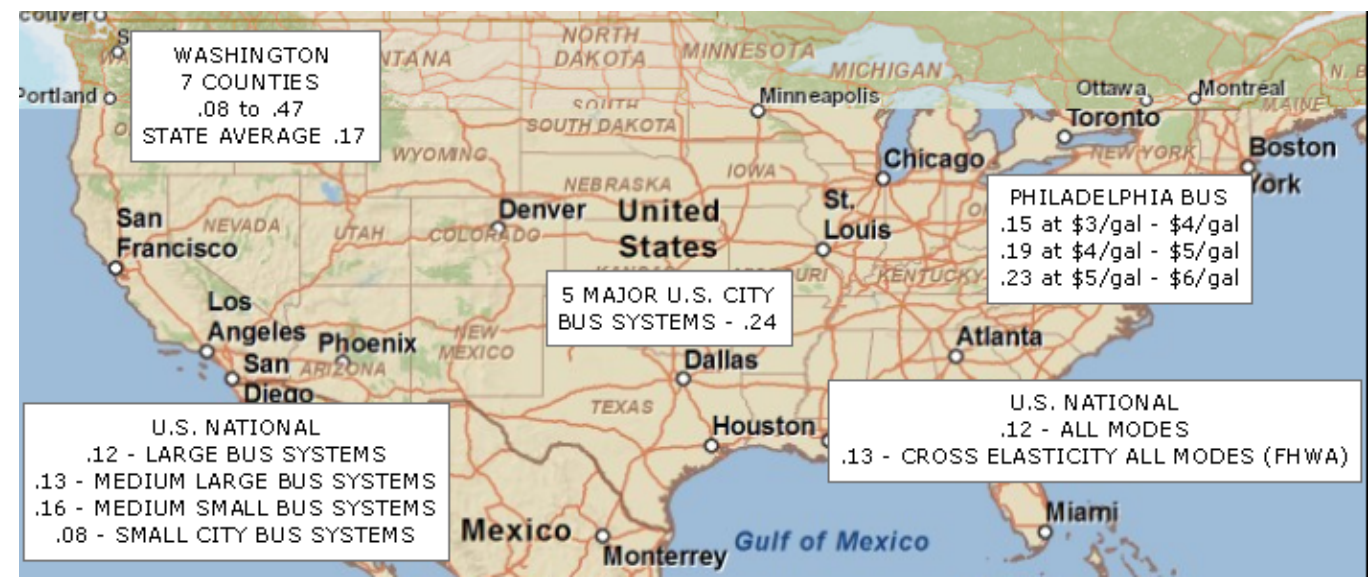

Figure ES-1: Geographic diversity of transit demand and gas price elasticities

\section{Transit Agency Analyses}

In a 31-month analysis period, local and express bus ridership hit their highest levels in both Broward and Hillsborough Counties in Florida in October 2008, approximately 3 months after the highest gas prices were reported. Performance of express bus routes in Tampa, Florida, three months after $\$ 4.00$ gas in July 2008 demonstrated the potential influence of the following conditions when gas prices were high, consistent with existing research:

- Higher levels of employment than service-area-wide averages

- Longer average travel time to work than service-area-wide averages

- Significantly lower numbers of households with zero vehicles available than servicearea wide averages

There were no discernible trends in the data at 12 months that demonstrated gas price influenced ridership.

\section{Stress Points in the Family of Transit Services}

A distinction is made between demand for rail and bus services as summarized from the case studies and other relevant findings from the literature review.

- 3 studies included commuter rail and found one elasticity of 0.27

- 4 studies included heavy rail and found a range of elasticities from 0.17 to 0.26

- 4 studies included light rail and found a range of elasticities from 0.06 to 0.38

- 5 studies included bus and found a range of elasticities from 0.04 to 0.24 
The findings indicated rail services are more likely to see increased demand than bus services when gas prices rise. This is particularly true in major cities where rail is a viable alternative to the automobile. Figure ES-2 provides a generalized, spatial perspective of transit demand and gas prices by transit mode. Commute trips with longer travel distances and available auto alternatives are more elastic and transit services providing trips to dependent riders, for short, non-commute trips are likely inelastic.

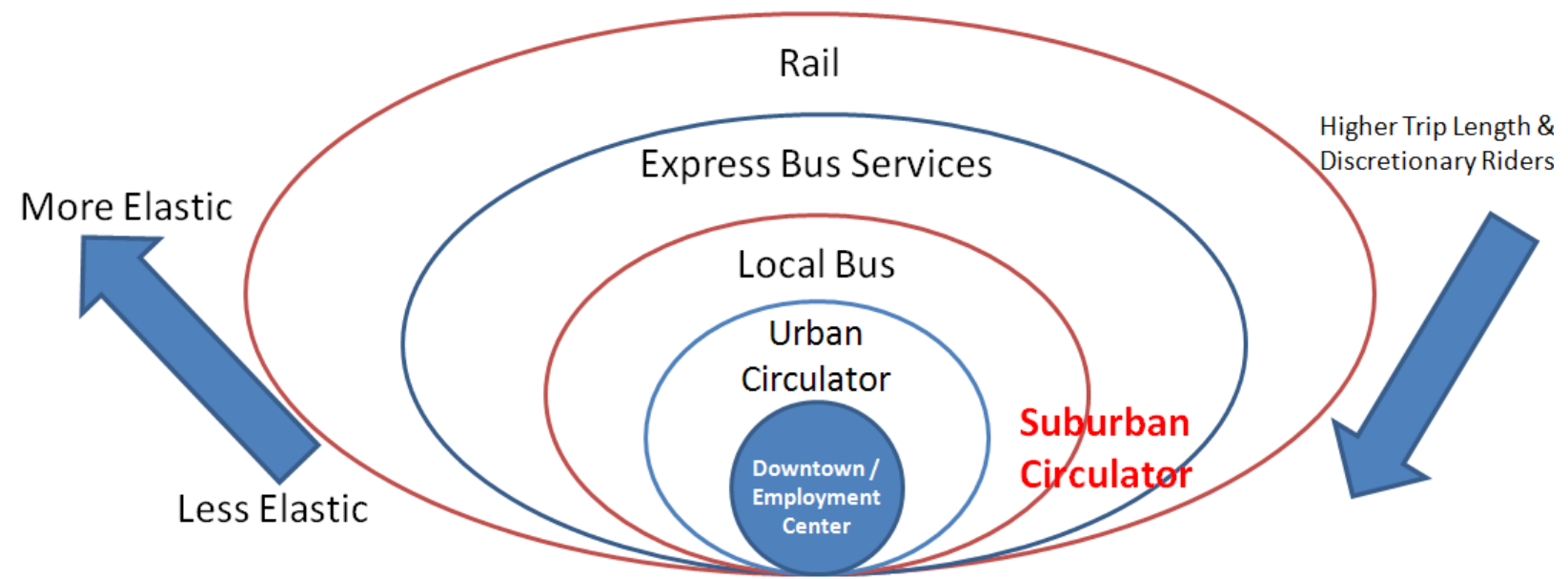

ES-2: Visual representation of elasticity of transit demand with respect to gas prices by transit mode

\section{Florida Transit Operator Survey}

A 23-question survey was taken by total of 22 individuals representing an unknown number of transit agencies. The purpose of administering this survey was to document the experiences of operators in Florida by building upon previous research, filling gaps within existing knowledge.

The predominant perceptions about gas prices and transit demand were:

- $\$ 4.00$ per gallon consumer gas prices do positively influence ridership at transit agencies, while half as many respondents believed $\$ 3.50$ gas also triggers ridership increases

- Service types most affected when prices increase are fixed route (local) and express or limited stop service

- When gas prices increase, fixed route and express or limited stop are service types recommended for improvements

- Consistent with previous research findings regarding brief lags and asymmetry, most respondents stated that ridership increases immediately after gas price spikes and that some ridership is maintained as prices go back down

- Local media attributes at least some increases in ridership at agencies to gas prices. 
The predominant perceptions about strategies to manage the effects of high gas prices (within a larger context of balancing operating budgets) were:

- Many agencies purchase fuel for owned and operated vehicles via multi-year agreements with contract-defined fixed pricing

- Most agencies are contracting out at least some portion of their transit service with a provision to allow the contractor payments to be adjusted for increasing fuel costs based on a defined formula

- Half of reporting individuals work for agencies that operate alternative fuel vehicles, which in many cases, comprise more than half of their fleet

- The top 2 reasons for operating alternative fuel vehicles are to decrease the amount of pollutants emitted by vehicles and to save money on fuel costs

- Marketing and outreach activities are undertaken to persuade people to use public transportation as a way to save money.

\section{Strategies for Transit Management in Times of High Gas Prices}

An assembly of transit demand management strategies was categorized into both those that can be used immediately to adapt to rapid price rises, as well as long-term strategies that can lessen the impact gas prices have on transit provision over time. The candidate rider market is the discretionary rider, on commute trips, during peak-hour service with travel times that can be improved or at minimum is made comparable to private auto.

\section{Short-Term Strategies}

There are a number of activities that could be employed to quickly respond to vehicle crowding or full vehicles based on information gained from the literature review, APTA study, and the survey described in Chapter 4. These actions are described below:

\section{Service Optimization}

\section{Contingency Fleets}

These reserve vehicles are typically those that have reached their useful life as defined by FTA and are kept to be used in emergencies or during special events. Contingency vehicles are best suited to address short-term fluctuations in price and demand; they could be quickly activated and put into service. More challenging may be the operating needs of new service. Short-term increases in vehicle operator hours and availability could be addressed through extra boards or be negotiated into labor agreements if demand increases as part extraordinary circumstances that require daily plug runs or trippers. 


\section{Coverage or Frequency}

The Florida transit operator survey found that at better than a 2 to 1 ratio, transit providers target service cuts from the least productive routes and route segments in the system rather than targeting service cuts where riders have other travel options. If reduction is sought for an area with riders that are highly sensitive to fuel price, transit agencies might consider cutting frequency before coverage (eliminating the route) as transit access has been found to be a key determinant of whether one uses transit. Access to transit during morning and afternoon peaks should be preserved even if off-peak service is diminished, as the research shows there is usually at least a short lag between the time gas prices go up and ridership starts to build when gas prices are high.

\section{Customer Service Suggested Alternatives}

Regions within the service area with sufficient levels of service may have more than one transit routing alternative available to complete a trip. Web-based trip planners and customer service agents should be able to offer more than one trip option when available. In particular, customer service staff should be aware of buses operating with crush loads and suggest alternative routes to passengers to maximize their potential to use the service.

\section{Marketing and Outreach}

One way to encourage ridership during times of high gas prices would be to conduct outreach or marketing campaigns within parts of the service area where there is commuteroriented service, long average commute times, high auto availability and adequate transit access. The U.S. Census and American Community Survey (ACS) publishes geographic data that can be mined for a more in-depth understanding of where these areas are within an agency's service zone. This could also include mailings with service maps and free ride passes to encourage individuals to try transit.

\section{Encourage Off-Peak Ridership, Consider Peak-Hour Fare Increases}

The research suggests peak-hour travel will be most highly demanded when gas prices go up. If levels of service are maximized during these times and demand exceeds what can be accommodated, a peak service ridership surcharge could be enacted to add revenues, encourage passengers to make off-peak trips if possible, and prevent a universal fare increase that may deter off-peak usage.

\section{Long-Term Strategies}

Long-term actions are those that best maximize the ridership potential from high gas prices over a year or longer and help stabilize budgetary impacts from the cost of fueling the fleet of vehicles that provide service.

\section{Flexing Funds Between Capital and Operating Needs}

The flexibility allowed by recent FTA formula funding rule updates gives transit agencies the opportunity to shift some previously ineligible capital funds into activities that could help sustain operations. The risk is that, with such a shift, the transit agency might not have 
enough funds to purchase new vehicles or other capital facilities or equipment necessary to provide a quality service in the long run.

\section{Fuel Contracts}

Transit operators can perform a risk assessment and tie the results to the type of fueling arrangements that best fits their situation. The tradeoffs in these arrangements are typically predictability of pricing versus the amount of risk involved.

Contract-defined fixed pricing provides for the greatest amount of predictability for budgetary reasons but is highly inflexible. Fixed-price contracts with a defined adjustment formula are one way to share some of the risk taken associated with purchasing fuel while preserving some budgetary reliability. Formulas may be indexed to a source that tracks the industry, such as the 'Oil Price Information Service' and set with thresholds that triggers adjustments in the event prices increase or decrease to some extreme. Transit operators may have access to refueling at agency-operated fueling facilities. There is a cost savings often realized with these arrangements, complemented by an increased administrative requirement for tracking usage. Direct cost reimbursement treats fuel prices as a passthrough cost. These arrangements assume considerable risk for the agency with little or no budgetary predictability. These same methods for fuel purchases can also extend into service contracted by the transit agency. A comprehensive risk assessment as part of the overall budget process can balance the appetite for risk along with defining optimum fuel price targets so that high gas prices will not hinder the ability for an agency to provide service.

\section{Alternative Fuel and Propulsion Vehicles}

The Florida operator survey asked respondents why their agencies purchase alternative fuel vehicles. The second highest response, only behind reducing pollution, was to reduce fuel costs.

\section{Service Optimization}

Optimizing service in the era of high gas prices would focus on development of premium transit options; such as BRT or express service. This would include any efforts to make the bus system more attractive to discretionary riders with infrastructure and technology investments. Some agencies also include factors for gas prices within their long-range transit demand models, with different factors included at multiple price points for gas prices. This may be particularly useful when resources are available to expand service, as discretionary markets may be the only ones where significant growth could occur.

${ }^{1}$ Bureau of Labor Statistics, Consumer Price Index for "Gasoline - All Types", Accessed March $22^{\text {nd }}, 2013$ from http://data.bls.gov/cgi-bin/surveymost.

2 U.S. Department of Energy, Independent Statistics and Analysis, Accessed February $11^{\text {th }}$, 2013 from www.eia.gov/todayinenergy/detail.cfm?id=9831.

${ }^{3}$ Federal Highway Administration, Statistics. Accessed January 19 ${ }^{\text {th }}, 2013$ from http://www.fhwa.dot.gov/policyinformation/travel/tvt/history/.

${ }^{4}$ Matthew Bomberg and Dr. Kara Kockelman (2011). "Traveler Response to the 2005 Gas Price Spike", Presented at the $86^{\text {th }}$ Annual Meeting of the Transportation Research Board, $\mathrm{p}$. 2. 


\section{Table of Contents}

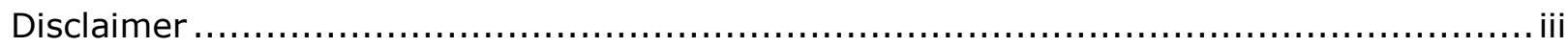

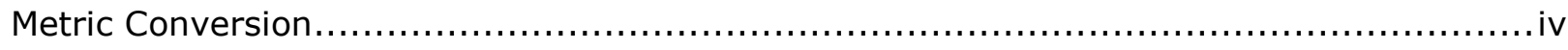

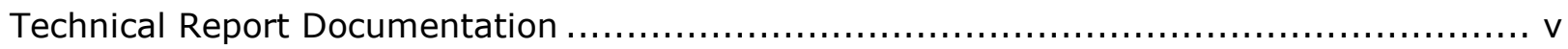

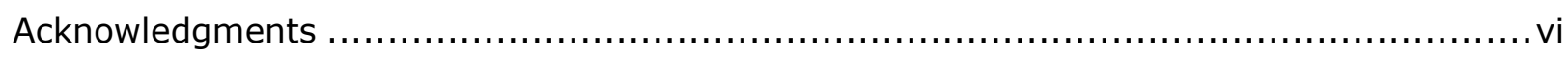

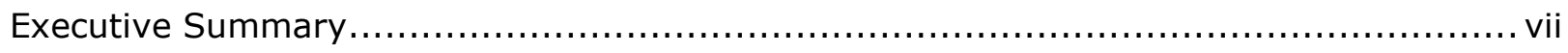

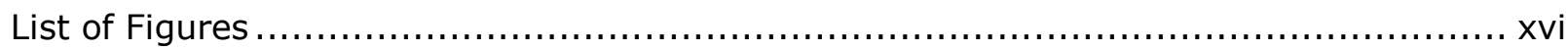

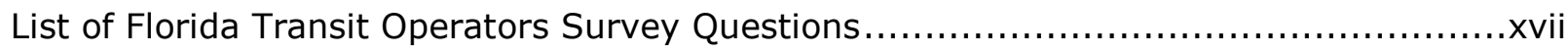

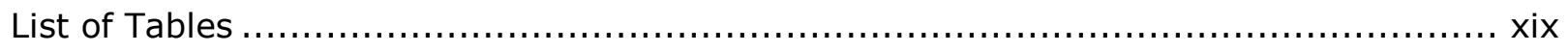

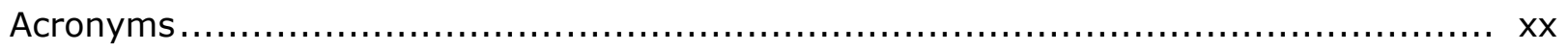

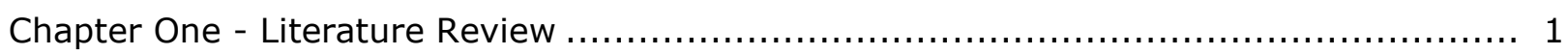

How Does Travel Behavior Respond When Gas Prices Go Up? ........................ 2

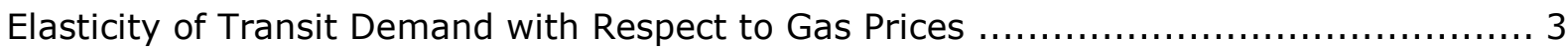

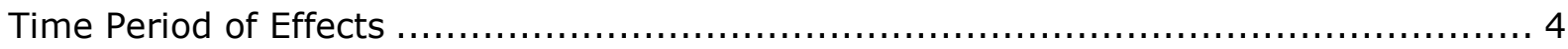

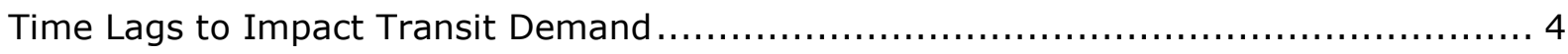

Direction of Price Change Engenders an Asymmetrical Response ..................... 5

Transit-Demand is More Elastic for Users with Other Travel Options $\ldots \ldots \ldots \ldots \ldots \ldots \ldots \ldots \ldots 6$

Commute Trips and Peak- Versus Off-Peak Travel Elasticities $\ldots \ldots \ldots \ldots \ldots \ldots \ldots \ldots \ldots \ldots 6$

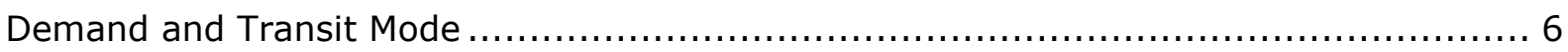

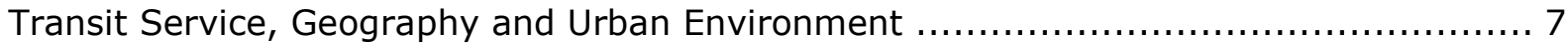

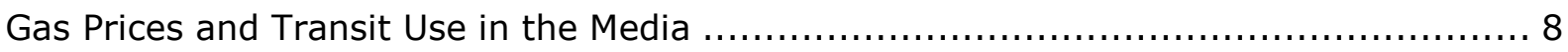

Strategies to Manage Increasing Transit-Demand in the Literature $\ldots \ldots \ldots \ldots \ldots \ldots \ldots \ldots \ldots \ldots \ldots \ldots \ldots \ldots \ldots$

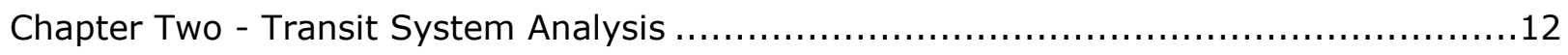

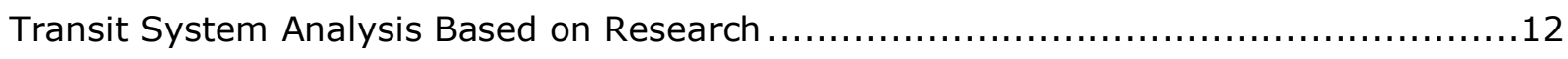

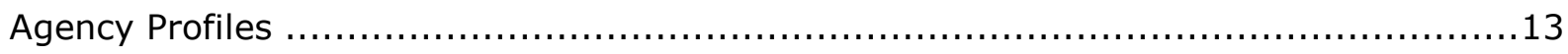




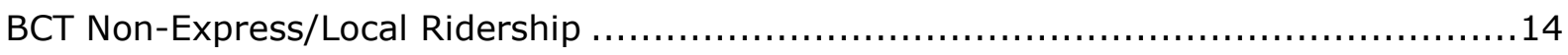

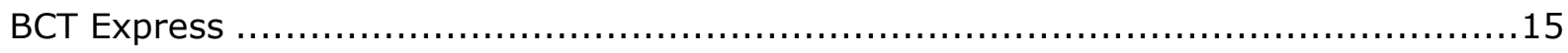

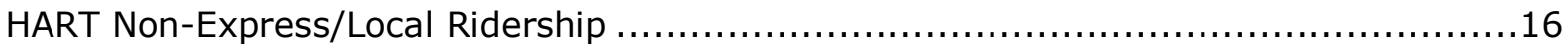

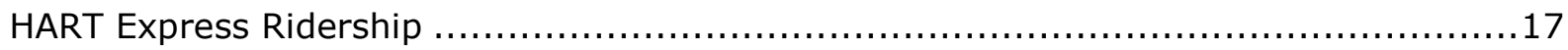

HART Non-Express/Local Passengers per Revenue Hour ............................ 17

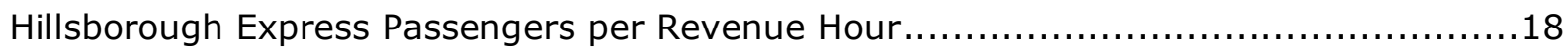

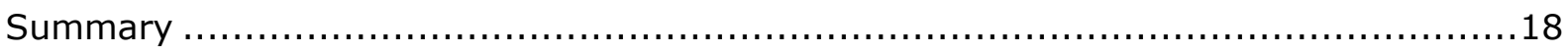

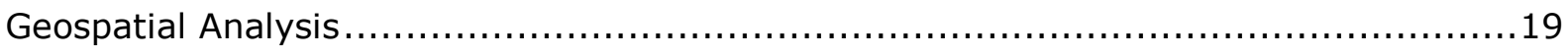

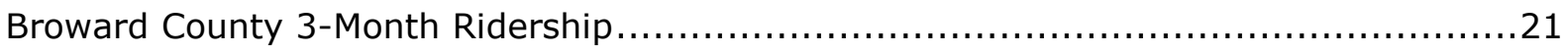

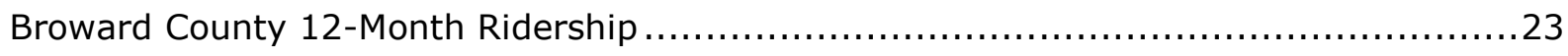

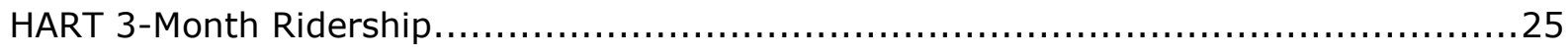

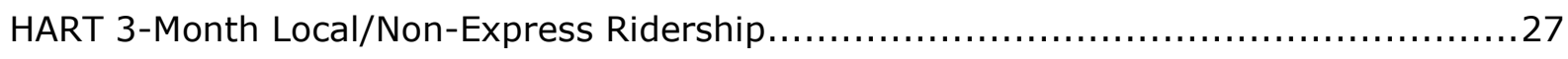

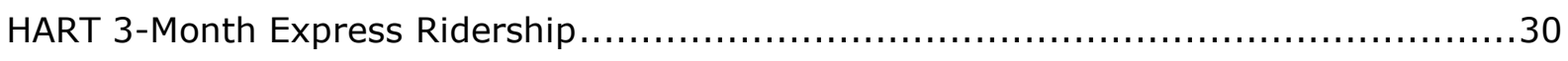

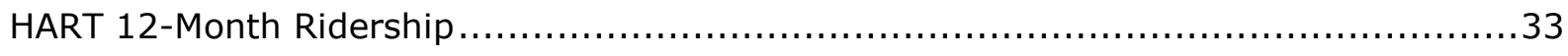

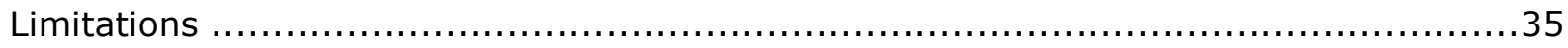

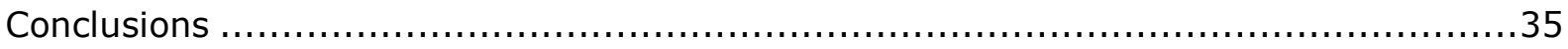

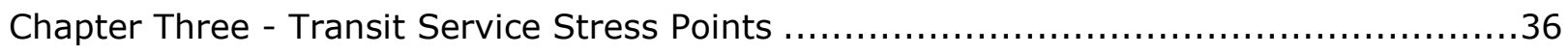

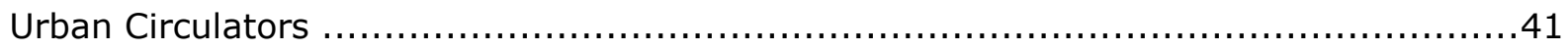

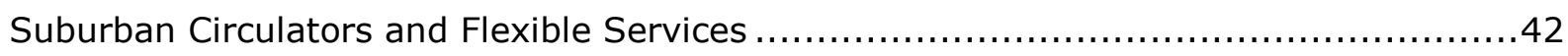

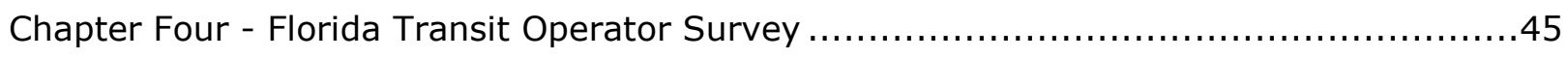

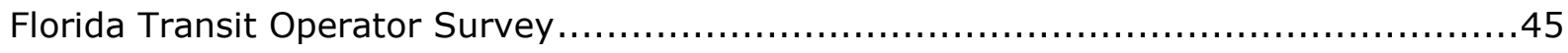

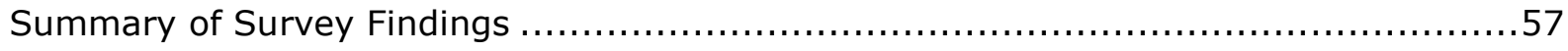

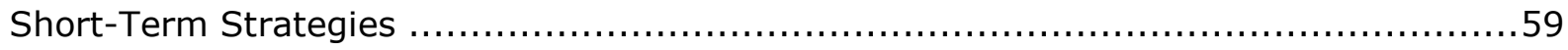

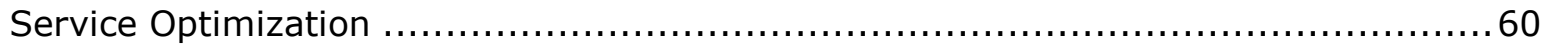

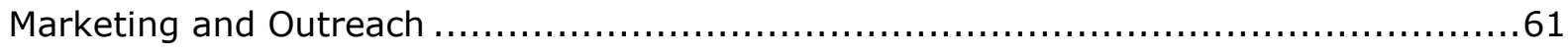

Encourage Off-Peak Ridership, Peak-Hour Fare Increases ............................61

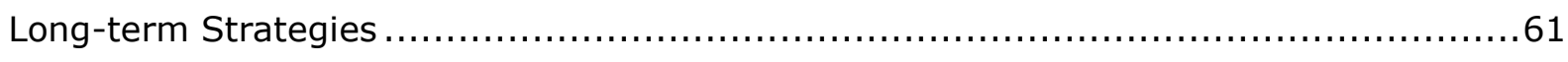




\section{Effectively Managing Consumer Fuel Price Driven Transit Demand}

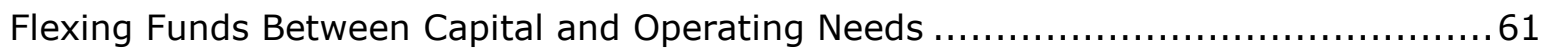

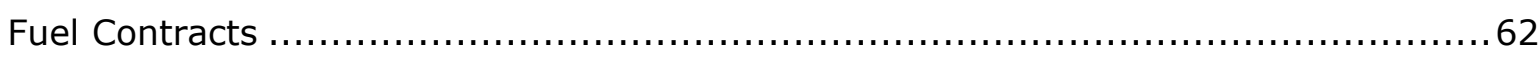




\section{List of Figures}

Figure ES-1: Geographic diversity of transit demand and gas price elasticities viii

Figure ES-2: Visual representation of elasticity of transit demand with respect to gas prices by transit mode ix

Figure 1-1: Transportation costs as a percentage of household income (Source FHWA) .... 1

Figure 1-2: Geographic diversity of transit demand and gas price elasticities ..............4

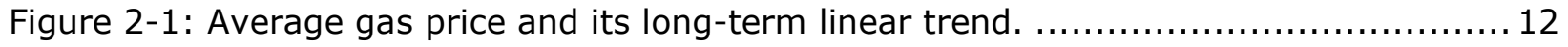

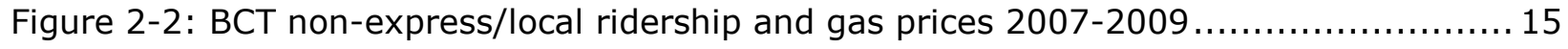

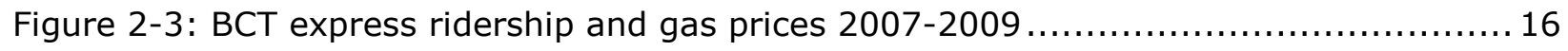

Figure 2-4: HART non-express/local ridership and gas prices $2007-2009 \ldots \ldots \ldots \ldots \ldots \ldots \ldots$

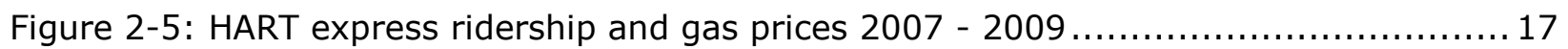

Figure 2-6: HART non-express/local passengers per revenue hour and gas prices 20072009

Figure 2-7: HART express passengers per revenue hour and gas prices 2007- 2009 ........ 19

Figure 2-8: BCT routes with increases at 3 -month post $\$ 4.00$ gas $\ldots \ldots \ldots \ldots \ldots \ldots \ldots \ldots \ldots \ldots \ldots \ldots \ldots \ldots \ldots \ldots \ldots \ldots$

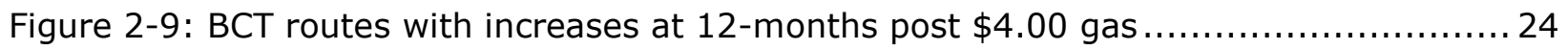

Figure 2-10: All HART routes with increases at 3 -months post $\$ 4.00$ gas $\ldots \ldots \ldots \ldots \ldots \ldots \ldots . \ldots . \ldots . \ldots . \ldots$

Figure 2-11: HART local routes with increases at 3 -months post $\$ 4.00$ gas $\ldots \ldots \ldots \ldots \ldots \ldots . . . \ldots 28$

Figure 2-12: Hart express routes with increases at 3 -months post $\$ 4.00$ gas................ 31

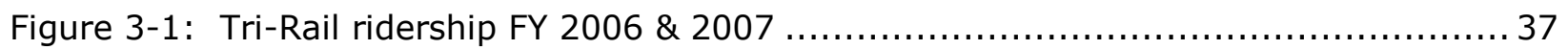

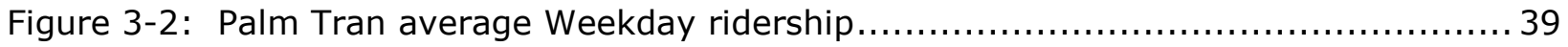

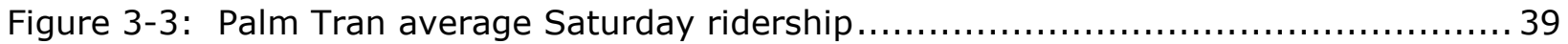

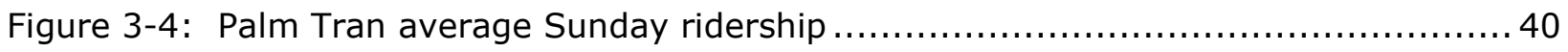

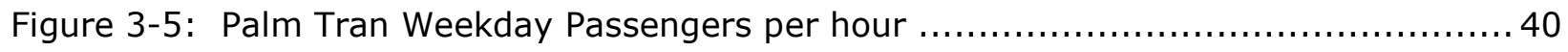

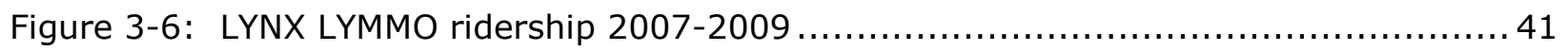


Figure 3-7: Visual representation of elasticity of transit demand with respect to gas

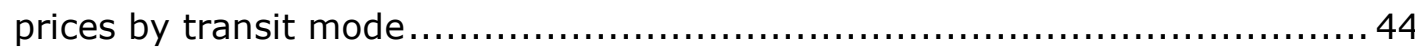




\section{List of Florida Transit Operator}

\section{Survey Questions}

Question 1: What type of role(s) do you perform in your transit agency? .................46

Question 2: How many years have you worked at your current transit agency? ............46

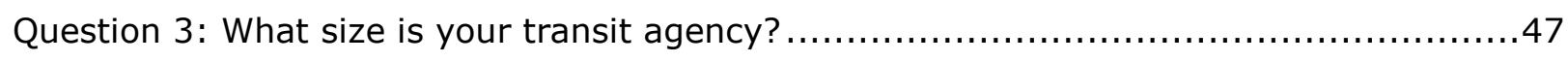

Question 4: Does your transit agency offer any of the following services? ..................47

Question 5: Gas prices notably reached $\$ 4.00$ per gallon in many places in July 2008 and almost did again earlier in 2012. Has your agency ever experienced an actual or perceived increase in ridership or demand that was thought to be caused by high gas prices?

Question 6: Which of the following services experienced an increase in ridership demand due to high gas prices at your transit agency? [Click all that apply].

Question 7: Should gas prices exceed $\$ 4.00$ per gallon again, which of the following services would you recommend to be increased? [Click all that apply].

Question 8: Which of the following price thresholds for gasoline appear to trigger increases in ridership demand at your agency? [Please click all that apply].

Question 9: Please check the scenario below that most accurately reflects your ridership or demand when gas prices increase.

Question 10: Did your local media attribute any increases in ridership to higher gas prices?

Question 11: Has your transit agency raised fares in recent years to compensate for either a decline in operating revenue or increase in diesel prices for bus operations?

Question 12: Has your transit agency cut service in recent years to compensate for declining operating revenue?

Question 13: Does your transit agency or county government (if applicable) purchase fuel via multi-year contracts? Fuel price contracts lock in a fixed price for gasoline and typically are used for budget predictability year over year and to hedge against future rises in gas prices.

Question 14: What are the mechanisms in your fuel contract(s) that define how fuel costs are to be paid? [Click all that apply]. 
Question 15: Does your transit agency contract any portion of its service to a third party?

Question 16: When using third parties to perform transportation services on behalf of a transit agency, there are often different methods for sharing fuel costs over the life of the contract. Are you aware of any of the following methods for fuel price costs sharing? ....

Question 17: Does your transit agency operate alternative fuel vehicles? .54

Question 18: What percentage of your fleet operates on alternative fuels?

Question 19: Please rank from most important (1) to least important (7) the reasons why your agency operates alternative fuel vehicles.

Question 20: Does your transit agency maintain a contingency fleet? The Federal Transit Administration defines a contingency fleet as: Buses may be stockpiled in an inactive contingency fleet in preparation for emergencies. No bus may be stockpiled before it has reached the end of its service life. Buses held in a contingency fleet must be properly stored, maintained and documented in a contingency plan. These vehicles do not count in the calculation of spare ratio.

Question 21: Does your transit agency use promotions such as Dump the Pump or other marketing initiatives that promote transit use directly based on the high price of gasoline?

Question 22: In summary, does your transit agency use any of the following SHORTTERM strategies to manage demand from gas prices to maximize ridership and preserve customer satisfaction? [Click all that apply]

Question 23: In summary, does your transit agency use any of the following LONGTERM strategies to manage demand from gas prices to maximize ridership and preserve customer satisfaction? [Click all that apply] 


\section{List of Tables}

Table 2-1: System profiles

Table 2-2: Routes in Hillsborough and Broward with ridership increases at 3- and 12-

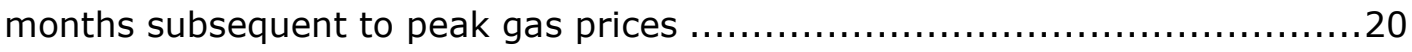

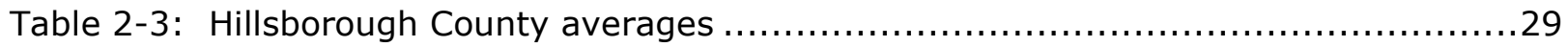

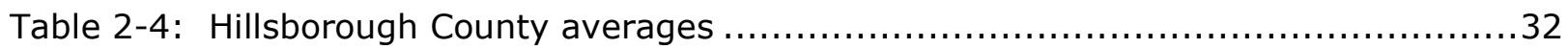

Table 3-1: JTA Service Standards ............................................................... 42

Table 3-2: TCRP 140- Flexible service markets.................................................43 


\section{Acronyms}

ACS

American Community Survey

APTA

American Public Transportation Association

BCT

Broward County Transit

BLS

Bureau of Labor Statistics

BRT

Bus Rapid Transit

CBO

Congressional Budget Office

CUTR

Center for Urban Transportation Research

DART

Dallas Area Rapid Transit

EPA

Environmental Protection Agency

ESRI

Environmental Systems Research Institute

FDOT

Florida Department of Transportation

FHWA

Federal Highway Administration

FON

Florida Operations Network

FRB

Federal Reserve Board

FTA

Federal Transit Administration

FY

Fiscal Year

JTA

Jacksonville Transit Authority

HART

Hillsborough Area Regional Transit

NCTR

National Center for Transit Research

TCRP

Transit Cooperative Research Program

USF

University of South Florida

VMT

Vehicle Miles Traveled

WMATA Washington Metropolitan Area Transit Authority 


\section{Chapter 1}

\section{LITERATURE REVIEW}

\section{Introduction}

The cost of personal transportation for many individuals and households typically represents a significant portion of their total income. These costs can be justified, as the convenience personal transportation provides may be necessary to commute to employment and make medical and shopping excursions among a variety of other reasons to take a trip. These costs typically includes of vehicle purchase or lease payments, automobile insurance, maintenance, parking fees and for most vehicles, fuel in the form gasoline. The cost of transportation is typically the second largest household expense, often far in excess of the $15 \%$ of total household income defined as affordable. ${ }^{5}$ Households in auto-dependent environments spend $25 \%$ of their income on transportation costs, as illustrated below in by the Federal Highway Administration (FHWA). ${ }^{6}$
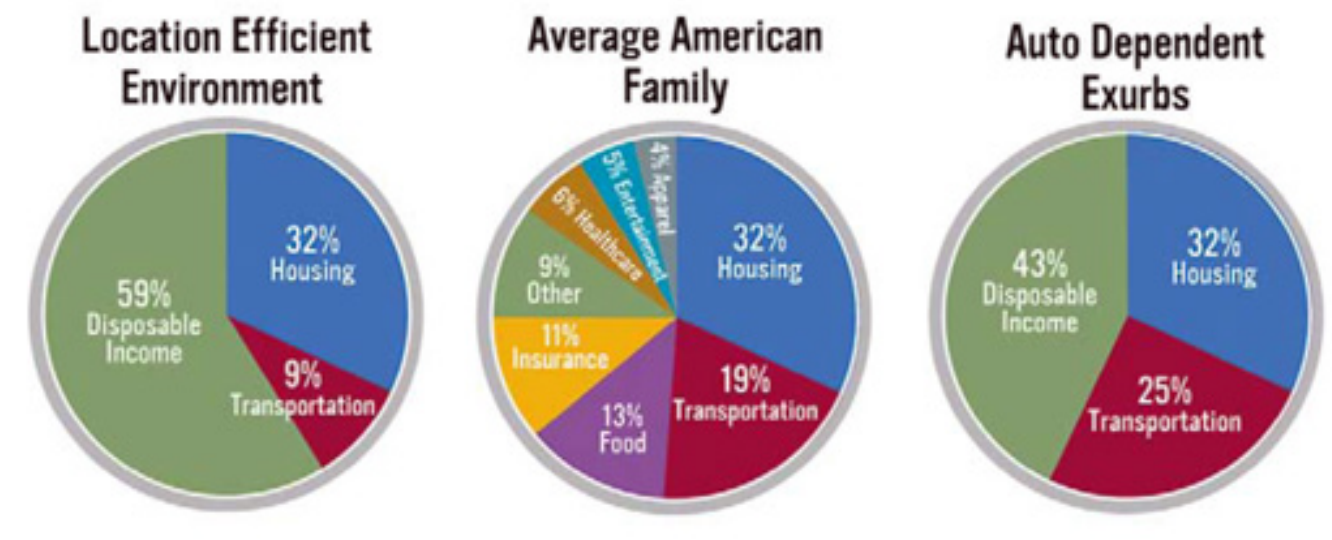

Figure 1-1: Transportation costs as a percentage of household income (Source FHWA)

While many costs within a household budget have increased in recent years, few have had such an impact than the rise in consumer fuel. The cost of gasoline to operate a personal automobile rose from $\$ 1.55$ per gallon in January 2003 to $\$ 3.40$ in January $2013^{7}$, an increase of $119 \%$. In 2012, gasoline represented $4 \%$ of pretax household income, the highest percentage in nearly 30 years. ${ }^{8}$ These additional costs may give individuals cause to reevaluate their transportation habits.

Indeed, total vehicle miles traveled in the U.S. decreased $4.6 \%$ from its peak in August 2007 to August 2011. ${ }^{9}$ Due in part to a depressed economy and higher unemployment, some previously made trips clearly were not taken. However, it has been demonstrated in several studies that some of these trips may have been instead made on public transportation. Aside from widespread media accounts and other anecdotal observations, 
research has demonstrated that certain modes of public transportation have seen ridership increases correlated to consumer fuel price increases. This study evaluated that research and sought to identify any predominant demographic or socioeconomic factors found in the existing literature.

The purpose of this study was to:

1. Understand the basis of the relationship between gas prices and transit demand and summarize elasticities that have been found in other studies across a variety of other variables

2. Describe features of transit's service area population that may be more sensitive to fuel prices and document their socioeconomic and demographic composition

3. Identify where stress points in the family of transit services may emerge

4. Assemble short- and long-term strategies for transit providers to manage volatility in fuel prices

The literature review included a summary of the demand elasticity of public transit as influenced by consumer gas prices. Studies reviewed included those of national, regional and local significance and included identification of which transit modes appeared to benefit most greatly from a rise in gas prices. Two mid-sized Florida transit agencies operating in the Tampa and Fort Lauderdale, Florida, and metro areas were analyzed in greater detail for impacts during what may be the most psychologically significant threshold consumer fuel prices reached in recent times, what became known as '\$4.00 gas' in July 2008.

The goal for a public transportation operator would be to maximize ridership and preserve customer satisfaction during times of increased gas prices. A survey of Florida's transit operators captured site-specific impacts and management plans that may have been used to both manage high fuel prices in transit operation and adequately serve any additional demand experienced.

The report concludes with a set of strategies transit operators can employ to help accommodate transit demand, encourage new or infrequent riders to take trips on transit, and manage the costs associated with increased fuel price to operate transit vehicles.

The relationship between consumer gas prices and transit demand has been well studied in recent years. Researchers have considered a number of conditions beyond the establishment of a statistically significant relationship between the two variables. The literature review is organized to first capture a general assessment of the relationship as reported in other studies, followed by gas price and transit demand elasticities. Where studies have found a correlation between the two, other findings are presented in the report such as sensitivity by mode, time of day, geography and urban area, trip purpose, and user demographics and preferences. The results of the literature review were the foundation for in-depth analysis of two Florida transit agencies, a transit operator survey, and recommendation of strategies.

\section{How Does Travel Behavior Respond When Gas Prices Go Up?}

The primary effect of rising gas prices on driving behavior is fewer total vehicle miles traveled (VMT). There have been annual decreases in national VMT every year since 2007, 
with the exception of $2010 .{ }^{10}$ Over that same time period, gas prices have increased upwards of $30 \% .{ }^{11}$ This negative relationship between gas prices and VMT has been reported with varying degrees. A 2008 Congressional Budget Office (CBO) study of gasoline prices and driving behavior found VMT not very responsive to the price of gas. The estimate reported was that a $10 \%$ increase in gas price was estimated to reduce VMT by as little $0.2 \%$ or $0.3 \%$ in the short-run and by $1.1 \%$ to $1.5 \%$ 'eventually'. ${ }^{12}$ Bomberg and Kockelman found these trips were displaced to other modes (including transit) and in part eliminated by trip chaining, or linking trips that were previously made independently. ${ }^{13}$

The Federal Highway Administration (FHWA) illustrated the dominance of highway travel when looking at the increase of 420 million transit passenger trips to the decline of 90 billion VMT on streets and highways meaning that only a small fraction of highway travel was diverted to transit ( $5 \%$ or less) when gas prices rose. ${ }^{14}$ From the first 10 months of 2007 to the first 10 months of 2008; gas prices rose $30 \%$, VMT fell $3.5 \%$ and transit use was up $4 \% .{ }^{15}$

\section{Elasticity of Transit Demand with Respect to Gas Prices}

Due to the relatively low mode share of transit nationally and the fact that about only half of the U.S. population has access to transit, any increases in public transportation use will represent a small fraction of total travel. Within this small subset of total travel, many studies have identified a statistically significant relationship with respect to transit demand where access was available during times of gas prices increases.

The FHWA found a gas price cross elasticity of +0.13 or a $4 \%$ ridership increase for every $30 \%$ rise in gas prices in 2008. This is in line with research in 2007 that established that for every $10 \%$ increase in gas prices, U.S. transit demand has increased by $1.2 \%$, a cross elasticity of demand to gas prices of $+0.12 .{ }^{16}$

Haire and Machemehl studied five major U.S. cities; Atlanta, Dallas, Los Angeles, San Francisco and Washington, D.C. and found that as fuel prices increase by $1 \%$, transit demand on average increases $0.24 \% .{ }^{17}$ This represented a larger increase than other studies have found and is likely related to the higher service levels in these cities.

Eleven transit service providers in Washington State serving populations from of 168,000 to $1,900,000$ were studied by Bae and Stover in 2011. A total of 7 of the 11 service areas, including both the smallest (Benton) and largest (Seattle) providers, were found to have a positive statistical correlation between gas prices and transit ridership, ranging from 0.08 to 0.47. Ridership on large urban systems seemed less affected by gas prices than small systems. This study also found service levels and the unemployment rate statistically significant influences on transit demand. ${ }^{18}$

Mattson found statistically significant relationships between gas prices and transit use in large and medium-to-large cities at 0.12 and 0.13 respectively, medium-to-small cities at 0.16 and small cities at $0.06 .{ }^{19}$ In a case study of Philadelphia, Maley and Weinberger defined the elasticity of ridership by fuel costs at particular price points. The elasticity increased from 0.15 at $\$ 4.00$ per gallon gas to 0.19 at $\$ 5.00$ per gallon gas, then topping out at 0.23 for $\$ 6.00$ per gallon gas. This suggests there may be some compounding effects as gas prices rise to new, previously unmet thresholds. 


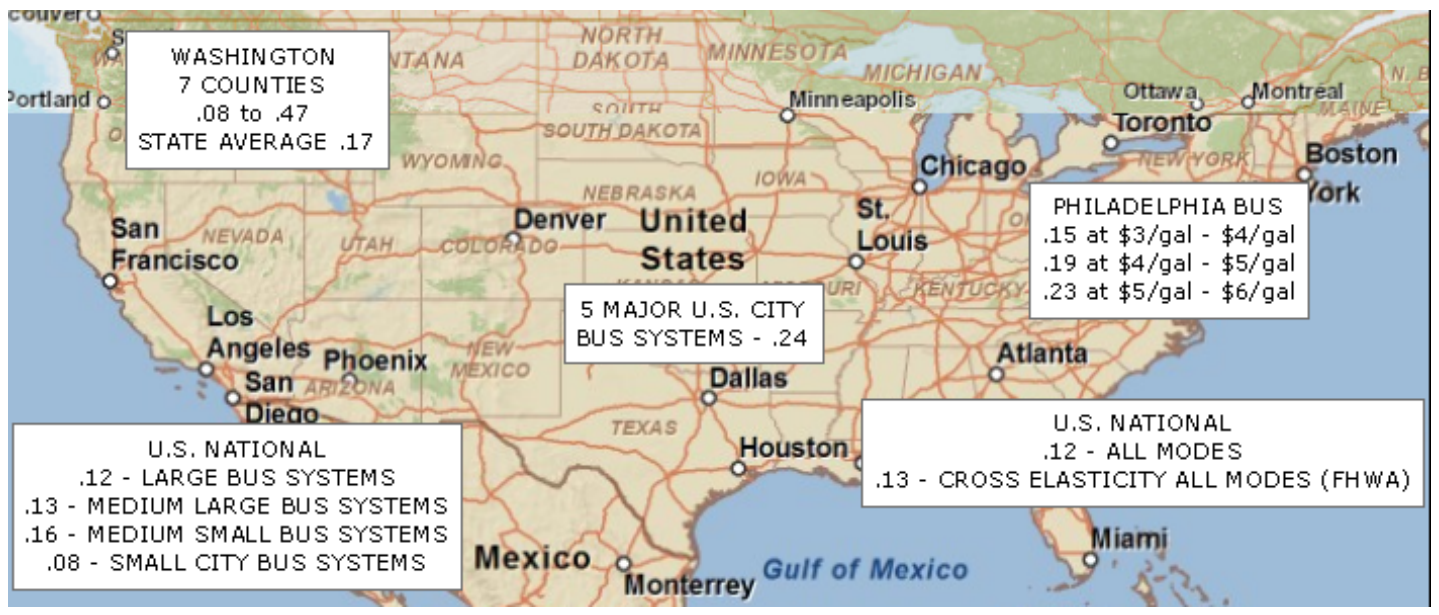

Figure 1-2: Geographic diversity of transit demand and gas price elasticities

When assessing various types of price change elasticities, Litman finds transit fares, service quality and parking pricing tend to have the greatest impact on transit ridership while fuel price tends to have relatively little impact. ${ }^{20}$ Wang and Skinner found neither fare nor gasoline variables for Miami, Florida are statistically significant while Jacksonville, Florida was found to be statistically significant for gasoline at $0.18 .^{21}$ Chen, Varley and Chen find that the causal link between the cost of fuel and ridership is unclear based on a study that identified elasticities of 0.11 for short-run effects and 0.18 for a long-run effect.

\section{Time Period of Effects}

Price impacts can be categorized as short-term, typically, within one year, and mid to longterm, more than one year. Elasticities increase over time, as consumers take price changes into account in more decisions such as where to live or work. ${ }^{22}$ Long-term transit elasticities are found to be two or three times as large as short-term elasticities. ${ }^{23}$ Currie and Phung found long-run elasticities of gas prices and transit demand to be 1.5 to 3.0 times larger than short-run values. ${ }^{24}$

Chen and Chen describe that changes in gasoline prices likely gradually find their way in the demand for transit over a period of several months or possibly longer. The accumulated change over that period is the long-term response. Long-run elasticities are consistently found to be more significant than short-run elasticities. ${ }^{25}$ Holmgren performed a metaanalysis of gas price elasticities for America and Australia and found a 0.82 short-run elasticity and a 1.15 long-run elasticity. ${ }^{26}$

\section{Time Lags to Impact Transit Demand}

The short-, mid- and long-term impacts of gas prices may not typically begin immediately following changes in prices. Lag effects have been associated with certain factors that could provide transit operators a timeframe to expect and plan for service adjustments to make any necessary accommodations.

In 1986, Rose conducted one of the earliest studies on lag and discovered the effect when analyzing the impacts on ridership when altering levels of service supply. Changes in 
ridership were found to lag 12 and 13 months past changes in transit supply when examining time-sequenced transit ridership in Chicago. Rose rationalized that demand for transit is often not instantaneous, taking time to emerge because of delays in information dissemination, existence of a 'cumulative effect', or short-term constraints. ${ }^{27}$

Time lags to transit demand impacts when gas prices increase have been identified within several studies. Yanmaz-Tuzel and Ozbay found a statistically significant positive relationship between gas prices and ridership only after several months. The correlation between transit ridership and gasoline prices showed that at 3 and 4 months in 2005 and at 2 and 3 months in 2008, time lags were statistically significant for price increases. ${ }^{28}$ Their results suggest that travelers may consider trends in gasoline price levels before making long-term decisions and switching modes and that several months elapse between the price change and the change in the transit demand. ${ }^{29}$

Lags were found to be most significant at one month for bus, heavy and light rail in a 2011 analysis of New Jersey transit ridership increase correlated to fuel price. ${ }^{30}$ Chen, Varley and Chen found lags in their results both immediately and at 13 months later. ${ }^{31}$ They surmised that residual seasonal effect could contribute to the 13-month lag relationship. Currie, and Phung reviewed Australian and American studies and discovered some evidence of a 7 to 8 month time lag between gas price changes and resultant impacts to transit demand. ${ }^{32}$

Mattson's findings of lag are presented by urban area size: ${ }^{33}$

- Large and medium-to-large cities respond to changes in gas price occurring in the month of or the month after the price change

- Medium-to-small cities have an immediate ridership increase following a change in the price of gas, but it is a smaller response and the effect of the price change continues for up to seven months

- Small cities have no significant response until after five months, and then the response is complete after seven months

Although the amount of lag is varied by study, transit demand from gas prices can be lagged in the short-term typically from 1 to 3 months and lagged until over a year later depending on local circumstances.

\section{Direction of Price Change Engenders an Asymmetrical Response}

Litman reports that transportation demand models often apply the same elasticity value to both price increases and reductions. However, his research identifies the relationship between fare prices and transit demand as evidence that changes may be non-symmetric. ${ }^{34}$ Chen, Varley and Chen found effects from changes in gas prices on transit ridership is small but significant and is derived from rise, but not the fall of prices. The curve that occurs as gas prices increase and transit ridership goes up is not symmetrical as gas prices decrease. ${ }^{35}$ The authors perform a visual inspection and formally quantify the ridership response to the rise and fall of gas prices.

Maley and Weinberger cite the post $\$ 4.00$ gasoline price drop of gas to $\$ 2.00$ per gallon with ridership remaining somewhat steady and conclude price may compel people to form new transit habits and may warrant additional research. ${ }^{36}$ 
The implication that ridership gained from gas price increases is somewhat 'sticky' in that some amount is retained when gas prices retreat to previous levels is found throughout data from previous studies, even when not brought forward for additional analysis as to why. It is likely an individual's change in trip patterns and travel behavior is not easily reversed unless transit use is considerably more inconvenient than driving.

\section{Transit-Demand is More Elastic for Users with Other Travel Options}

Litman most succinctly generalizes transit elasticities by user type. Two of the most prominent types are the transit-dependent rider, with few or no transportation alternatives and the discretionary rider who has other travel options available. Litman finds that transitdependent riders are generally less price sensitive than discretionary riders, or people who could drive for a trip. ${ }^{37}$ In many communities, individuals who are transit-dependent may be a relatively small portion of the total population but a large portion of transit users, while discretionary riders are a potentially large but more price sensitive market segment. ${ }^{38}$ This likely holds true when focusing on transit demand with respect to gas prices. To those who are transit-dependent, transit demand and gas price are particularly inelastic because users will be unburdened by those costs.

\section{Commute Trips and Peak- Versus Off-Peak Travel Elasticities}

A review of general elasticity of transit demand finds that non-commute trips and off-peak travel is more elastic than commute trips and peak hour travel. This is likely due to the fact work trips cannot typically be eliminated or rescheduled to off-peak times, whereas more discretionary trips are likely to be scheduled in the off peak. In fact, Litman summarizes this relationship for off-peak transit travel as typically being 1.5-2 times higher than peak period elasticities, mainly because peak-period travel largely consists of commute trips.

However, there is evidence the relationship is reversed when gas prices increase.

The January 2008 CBO analysis found work commuters are more likely to switch to transit during time of high gas prices, especially to rail if the available alternatives are convenient to workplaces. ${ }^{39}$ Storchmann found the elasticity of transit demand with respect to gas price is the highest for work (0.2) and school (0.12) and the lowest for leisure, shopping and holiday, (all >0.05). ${ }^{40}$ The logic of this response is that when there are viable transit trip alternatives to an auto commute in times of high gas prices, users will seek and evaluate those options.

\section{Demand and Transit Mode}

Gas price increases do not impact all transit modes equally. It has been expressed in the research that bus and rail often have different elasticities because they serve different markets. Rail users are more likely to own or have access to an automobile for a trip than a bus user and are less 'captive' to a transit trip. Therefore, it could be more likely high gas prices induce a transit mode switch from the auto user.

Large cities with rail and subway networks may not feasibly offer auto trip alternatives. U.S. light rail is particularly sensitive to gas prices, with elasticity values of 0.27 to $0.38 .{ }^{41}$ Currie and Phung also found bus ridership only slightly sensitive to gas prices (0.04), and heavy 
rail higher at 0.17 , consistent with other international evidence. Lane's findings were somewhat counterintuitive, describing a small but significant effect of fuel prices on transit usage in light rail and heavy rail in some cities yet commuter rail had no relationship. ${ }^{42}$

Maley and Weinberger find that in a case study of Philadelphia, the effects on ridership from a $\$ 1$ increase in fuel costs is twice as large for the regional rail system than it is for the City bus transit service. This reinforces the concept of choice rider and work commute trip being most price sensitive because of alternative options. A 2011 New Jersey Transit ridership analysis finds a $\$ 1.00$ increase in 1979 dollars would yield a $13 \%$ increase in bus ridership. There was a $12 \%$ increase for heavy rail and $34 \%$ for light rail in this study. It is important to note that the dollar in 1979 had significantly more value than current day but the percentages remain consistent with other research. ${ }^{43}$

The CBO report found that reductions in traffic volume correspond closely to increases in transit ridership. An analysis of light rail in Sacramento, Los Angeles and San Diego found when adjusting for long-term ridership trends in each system, seasonal effects and inertia that a $20 \%$ increase in gas prices would result in a $1.9 \%$ increase in ridership.

\section{Transit Service, Geography and Urban Environment}

The level or quality of service plays a large role in determining when gas prices drive transit demand. Yanmaz-Tuzel and Ozbay make the case that enough transit supply is needed to be a viable alternative to driving otherwise travelers would not switch no matter how large the savings as travel would be too inconvenient. However, gasoline prices may encourage transit use in cities that have established public transportation systems with large transitdependent residents, while many of the commuters also use the automobile. ${ }^{44}$

Morrison, Fuller and Knittel found that the most elastic areas of the country with respect to gas prices and driving are the southeast and midwest. They theorized this was due to these areas perhaps having the highest amount of discretionary trips. Other statistically significant variables were percent of urban population, population density and the rural/urban VMT ratio. ${ }^{45}$ Haire and Machemehl that the found effect of gas prices on bus ridership varies regionally and as gas prices increase in the north central and Midwest U.S., ridership there falls. ${ }^{46}$ The lack of regional consistency in the research suggests geographic considerations in the gas price and transit demand relationship are either not relevant or well understood.

Litman reported that large cities tend to have lower price elasticities than smaller cities and suburbs, probably reflecting differences in the portion of transit-dependent residents. ${ }^{47}$ However, Bomberg and Kockelman concluded that urban form, more than demographics, influenced behavioral response to gas price hikes as found in a 2005 survey in Austin, TX. ${ }^{48}$

Mattson's results show that the quicker response to changing gas prices in larger cities may be explained by the fact that people in large urban areas are generally more accustomed to public transit, so these individuals may be quicker to switch to transit during a period of high gas prices than those from smaller cities who may not be as familiar with their cities' public transportation options. Elasticity is lowest for the smallest cities, indicating that people in small urban or rural areas are less likely to switch to transit. The medium-to-small cities, though, have the highest response. ${ }^{49}$ 
Although there is typically less rural service available than urban service, there may still be increases in its use due to lack of auto availability and long trip lengths. Because of transit options, those who might otherwise be institutionalized can stay at home. ${ }^{50}$ In turn, there is a greater financial burden on transit agencies to perform trips that are more costly when gas prices rise. The suburbanization of poverty in recent years has created a greater need for transit away from where the service is most available. ${ }^{51}$ Poverty is highly indicative of transit use. Golub found the greatest losses in quality of life measures during times of high gas prices are found for commuters in corridors with poor public transit options rather than in corridors with well-performing public transit systems. ${ }^{52}$

In 2012, Sexton, Wu and Zilberman found that sudden fuel price increases tend to reduce the value of homes away from the city center, thereby increasing foreclosure rates. ${ }^{53}$ A U.S. Federal Reserve Board (FRB) study found that, after a four year lag, each $10 \%$ fuel price increase leads to a $10 \%$ decrease in demand for homes in locations with longer average commute relative to locations that are in close proximity to employment. ${ }^{54}$ These impacts, coupled with the lack of alternative mobility options outside of urban centers, suggest there could be a demand for service that is unable to be seen in the data as there are fewer modes available to use.

In summary, there are numerous examples of research that demonstrate there is a statistically significant relationship between gas prices and transit demand. The relationship is complex but can be generally characterized as positive, meaning as gas prices increase, ridership does so marginally in environments where there is service available to perform at least some of those same trips.

\section{Gas Prices and Transit Use in the Media}

The question of whether high gas prices increase transit ridership has been substantially discussed in print and television media in recent years. The relationship is usually presented as an overwhelmingly positive one; as gas prices increase so does transit ridership. To the contrary however, few studies have established cause between the two variables and where increases have been identified, they are typically small. The relevance of media presentation of transit use is that it may increase social acceptance and awareness of the viability of public transportation for some travelers, and in turn, drive increased ridership.

Since 2007, gas prices have increased more than $100 \%$ and for certain timeframes, have been coupled with nationwide increases in transit ridership. The following are examples from print reports that were found to be typical of the larger media portrayal of this relationship.

Media reports often cite spokespeople or other transit agency personnel as the basis for these assertions.

"Every time fuel prices jump, ridership spikes, as was the case in 2008", said one transit planning manager. "If I could point to one single thing, it'd be gas prices." 55

In other cases, gas prices are cited as a contributing factor for increased ridership along with other demand inducing activities, as shown in the following example:

'Transportation officials credit rising gas prices and a busy tourism and spring break season." 56 
Some media reports have gone into more detail, describing features in the relationship as described by experts or agency staff with supporting data.

Commuters hold a '\$4 threshold mentality.' said one marketing director. Historically, one agency stated when gas prices fall, their rail service has lost some ridership but doesn't reach previous lows. In the fall of 2008 , when gas prices dropped from roughly $\$ 4,10$ transit systems recorded their highest passenger counts, in October 2008. ${ }^{57}$

Americans took nearly 10.7 billion rides on public transportation in 2008, a 4 percent increase over the previous year according to the report, by the American Public Transportation Association, and use of public transportation in the United States has risen 38 percent since 1995 . Ridership surged after gasoline prices hit $\$ 4$ a gallon in summer and held steady in the fall after gas prices fell, the APTA report found. But few experts expect the growth to continue this year, in part because transit systems across the country are raising fares and cutting service as the tax revenue they rely on plummets during the recession. Transit officials were especially heartened that Americans continued to turn to public transportation in the last quarter of the year, even after gas prices dropped. ${ }^{58}$

The U.S. Secretary of Transportation has reinforced this view in an April 2012 blogpost. "Given the rise in gas prices that occurred during March, we expect ridership increases to continue. But fuel prices are only one of the factors that lead to increased ridership." 59

A smaller number of media reports have questioned the connection between gas price increases and behavioral change. In 2012, the Dallas Morning News published 'Gas prices and ridership, at DART the correlation is fuzzy' with a more skeptical view of the influence of gas prices. The Dallas Area Rapid Transit's (DART) agency head stated that ridership did peak in August 2008 with more than 73,000 average weekday riders. However as gas prices fell, so did ridership. ${ }^{60}$ An important point was made in the following quote. "Still, the bottom line from the transit agency leaders ... was that high gas prices draw new riders to the system, and so there needs to be more funding, not less. San Diego's transit chief, for instance, said the ridership there peaked in 2008 and hasn't gone down, not much anyway. Service has been cut badly there, thanks to dwindling sales taxes, but ridership remains equal to what it was in 2009." ${ }^{61}$

One media-published analysis describes the personal economic impact and why gas prices may not be of much influence on changing behaviors. 'But for the average American household, which has an income of over $\$ 62,000$ a year, the increase in gas prices represents a relatively small portion of total spending. For example, in 2008 gas prices were all over the news when they hit their all-time high. But in 2010 when prices fell people barely mentioned them. Yet spending on gas totaled only $\$ 12$ more per week in 2008 than in 2010, according to numbers provided by the Bureau of Labor Statistics (BLS). That $\$ 12$ per week is roughly the same amount that BLS figures show people spent on "pets, toys, hobbies and playground equipment." "The incremental expenditure is not that much," said Akshay Rao, a professor of marketing at the University of Minnesota's Carlson School of Management who has studied gas prices. "But that's not how people think about it, the media seizes upon the rising price because it makes a good headline."'62

Both the individuals and organizations finding ridership influenced by gas prices as well as critics of this idea due to the raw economics involved can both be correct. It may be the 
case that transit demand is increased when one cost that affects household income that is highly unstable (gas prices) can be replaced for one that may not be tremendously cost beneficial, yet is more predictable (transit use).

\section{Strategies to Manage Increasing Transit-Demand in the Literature}

These conditions create an opportunity for transit providers to better serve the needs of a growing rider base or for existing riders that could generate more trips during times of high fuel prices. The literature review describes several actions to consider when planning for an increase in demand.

One strategy is based on the idea that because elasticities vary widely between cities and modes, a one size fits all mechanism would be inappropriate. Instead, because transit supply has a strong positive coefficient across all modes, transit operators should work to create a more elastic supply of transit. ${ }^{63}$ This two-step process would begin with enhancing demand forecasting techniques to consider several levels of gasoline price, followed by practices to supply service flexibly so they can more quickly rise and fall with demand.

This is supported by Maley and Weinberger suggesting travel demand forecasting should involve various fuel cost scenarios utilizing an elasticity that captures mode shift in the event of a variety of future fuel price conditions. One example of this in practice can be found in the short-term modeling done in Washington, D.C. for the WMATA bus and rail networks. The model assumes a Metrorail weekday gas price elasticity of 0.04 to 0.07 and a Metrobus weekday gas price elasticity of 0.05 to $0.07 .{ }^{64}$ The small but significant effects of gas prices there were not seen on weekends and mirror other modeling efforts in similar cities in the 0.05 to 0.15 range.

The ability to accurately forecast and supply service to meet areas of demand in advance can lead to higher levels of ridership than operating reactively. Blanchard theorizes that if operators can accurately predict transit demand due to gas price increases, the estimated cross-price elasticity would be larger than predicted even if the actual impact of fuel prices on consumer behavior was constant. ${ }^{65}$ This strategy attempts to capitalize on transit demand to generate higher levels of ridership by adding supply, based on demand that may not be adequately met with existing levels of service.

Chen, Varley and Chen suggest that a policy of increasing gasoline price is preferred to decreasing a transit fare to encourage transit ridership. They base their findings on their research that shows that a rise in gasoline price will encourage ridership, but that a corresponding fall in transit fare will not increase ridership equitably. The findings of asymmetry support increasing gasoline price over decreasing transit fare to increase ridership. ${ }^{66}$

Mattson calls attention to the fact that not only are expenses for drivers higher but for transit agencies as well. ${ }^{67}$ Therefore, strategies to manage any demand associated with gas price increases should be complemented by actions to minimize the impact of fuel prices on transit agency budgets.

In September 2008, the American Public Transportation Association published a report titled; How Transit Agencies are Addressing the Impact of Fuel Price and Ridership 
Increases. The document provided a series of abbreviated case studies, with in-depth analyses of a number of transit agencies' actions taken to address escalating fuel price conditions in their service areas. The study considered that some providers at that time were beginning to lose local revenues and also had budgetary impacts from the same increased fuel prices that may have been driving record levels of ridership. This confluence of factors made the release of that report both timely and of practical significance.

The APTA report identified actions transit agencies could take to accommodate an increase in demand and maintain cost control. Demand management strategies included ${ }^{68}$ :

- Adding Services

- Expansion of Service Using Capital Dollars

- Marketing/Outreach to Attract New Riders

- Marketing/Outreach to Deal with Overcrowding

- Alternative Routing Suggestions

- Adjusting Service Standards

- Parking Improvements

- Contingency Fleets

- Re-configuring Vehicles to Increase Capacity

Maintenance of funding included both nationally and locally applicable activities, which included $^{69}$ :

- Assisting in Advocacy Efforts for More Stable Funding Sources

- National Energy Hedging Opportunities

- Realign Capital Improvement Funds and Flexibility for Existing Programs

- Lobby for More Federal Transit Funding

- Transit Purchasing Consortiums

The 17 interviews conducted for the report included transit agencies from across the U.S. but lacked a regional component in the southeast, outside of Louisville, KY. The need for regional examples is relevant in that some of the strategies for dealing with gas price impacts are unique, dependent on certain state and local programs and legislation that are not uniform with other national examples. It should be noted that the passage of MAP-21, provides new funding flexibility not available at the time of the 2008 report. 


\section{ChAPTER 2}

\section{TRANSIT SYSTEM ANALYSIS}

\section{Transit System Analysis Based on Research}

Given that gas prices are projected to remain relatively high for the near future, the marginal yet statistically significant impacts on transit ridership suggest continued growth as well. High gas prices, particularly over time, give individuals an opportunity to either adjust their household budgets to accommodate these costs or perhaps induce a consideration of public transit, for at least some portion of trips.

Case studies of the experience at two transit agencies in Florida provide further insight into the relationship between changing gas prices and transit ridership. This analysis looked at gas prices and ridership at two agencies during a 31 month period from January 2007 through July 2009. This period captured an 18 month escalation in gas prices and ridership up to July 2008, the peak of consumer fuel prices at or above $\$ 4.00$ per gallon nationally. The 12 months following June/July 2008 allowed for a comparison one year later.

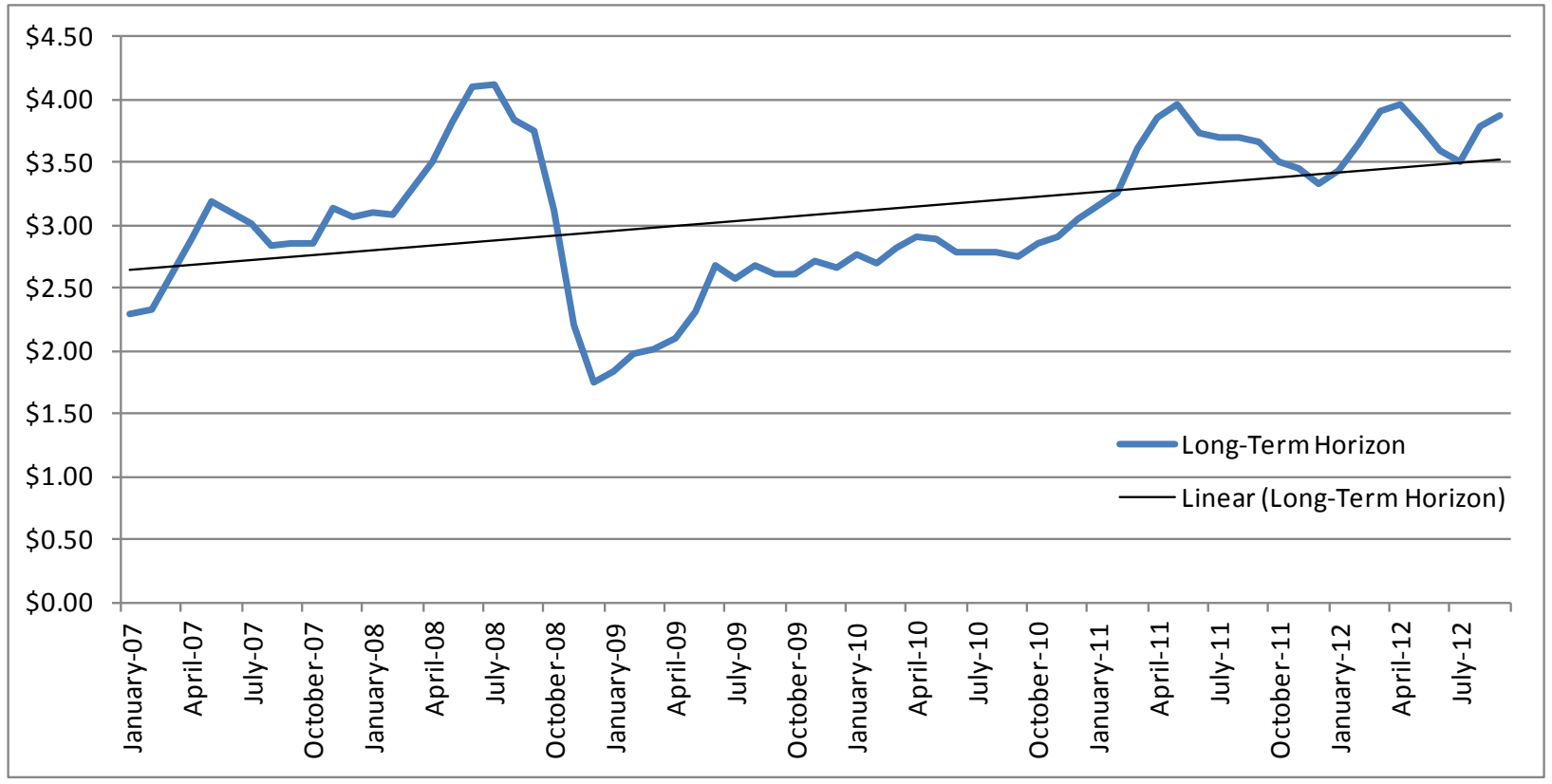

Figure 2-1: Average gas price and its long-term linear trend.

A review of both express and non-express ridership at the two agencies within line graphs is presented which will allow for a:

- View of immediate increases in ridership or short-term lags (1-3 months) 
- Year over year comparison (June/July 2008 \& 2009)

- Determination of any asymmetry in the ridership response to gas prices as they rise and fall

Separating express and local services provided for isolating rider demographics, average trip lengths and trip purpose. Local service would tend to have shorter trip lengths made by urban residents for a variety of purposes. Express service would tend to have longer trip lengths made by suburban residents primarily for commuting.

Following this review, a geo-spatial presentation of the data is shown, utilizing 5 variables demonstrated to influence the positive relationship between gas prices and transit ridership:

- Employment

- Mean travel time to work

- Average number of household vehicles available

- Percentage of zero vehicle households

- Total cost of transportation as a percentage of median household income

Because research indicates transit use is most elastic for discretionary users on commute trips, these variables were selected as supportive of that profile.

\section{Agency Profiles}

Broward County Transit (BCT) and the Hillsborough Area Regional Transit Authority (HART) are both primarily bus systems with HART operating a small amount of (approx. 1-2\% of total ridership) electric streetcar service. Both systems were chosen as to allow review of 2 regionally comparable systems to observe the similar and differing effects of gas prices and ridership for the 31 month evaluation period.

Table 2-1: System Profiles

\begin{tabular}{|l|r|r|}
\hline & \multicolumn{2}{|c|}{$2011^{*}$} \\
\hline & $\begin{array}{c}\text { Broward County } \\
\text { Transit (BCT) }\end{array}$ & \multicolumn{1}{c|}{ HART } \\
\hline & Fort Lauderdale, FL & \multicolumn{1}{|c|}{ Tampa, FL** } \\
\hline Service Area Population & $1,748,066$ & 822,404 \\
\hline Service Area Population Density & 4,263 & 3,384 \\
\hline Total Annual Revenue Miles & $15,799,243$ & $7,737,547$ \\
\hline Total Annual Revenue Hours & $1,153,339$ & 615,337 \\
\hline Total Revenue Vehicles & 382 & 218 \\
\hline Annual Passenger Trips & $38,279,640$ & $14,994,081$ \\
\hline Average Fare & $\$ 0.80$ & $\$ 0.87$ \\
\hline Passenger Trips per Revenue Mile & 2.42 & 1.94 \\
\hline Passenger Trips per Revenue Hour & 33.19 & 24.37 \\
\hline *From 2012 Florida Transit Handbook & & \\
\hline$* *$ *ncludes limited streetcar service & & \\
\hline
\end{tabular}


An initial review of the measures in Table 2-1 above, demonstrated that BCT has a more densely populated service area and performs more productively than HART. The geographic service area of HART is comparable to BCT, however the origins, destinations, and route structure lies within more of a grid network in Broward and with more hub and spoke features in Hillsborough.

Ridership was presented with gas prices divided into both local (non-express) ridership and express ridership. The first graph overlays monthly gas prices onto BCT's non-express monthly ridership for the analysis period.

\section{BCT Non-Express/Local Ridership}

BCT's local ridership moved up and down with as much as $10 \%$ variation month to month, as shown in Figure 2-2 two highest ridership months in the study period are March and August 2007, both 31 days months exceeding 3.4 million monthly rides. The third highest month in the study period is October 2008, three months after the gas price peak in July 2008. Shortly after these highs in fuel price and ridership, the data show decreasing ridership over the next several months.

Gas price decreases hit their lows in the end of 2008, at less than half of their earlier highs. However, BCT's sharp decline in ridership in the second half of 2008 might be explained by a number of factors.

A fare increase in October 2008 resulted in:

- $15 \%$ higher cost monthly passes, which are typically used by regular system riders

- $9 \%$ higher cost weekly passes

- $11.5 \%$ higher cost 10 ride passes

A service change effective in September 2008 reallocated hours out of midday service resulting in earlier and later daily trips on some routes. Service reallocation can result in passengers being inconvenienced in the short-term and some previous trips not being made.

This high level review of BCT local ridership and gas prices do not indicate any identifiable trends. The study period after $\$ 4.00$ gas is further complicated by the immediate fare increase that negatively impacted ridership. Therefore, while the decreases in ridership coincide with the drop of gas prices, the severity is likely amplified with the confluence of factors which all would lead to lower ridership.

- Gas price decreases result in lower cost trip alternatives to transit

- Fare changes increase the cost of a transit trip

- Service changes disrupt trip patterns, impact transit access, and may lead riders to seek alternatives 


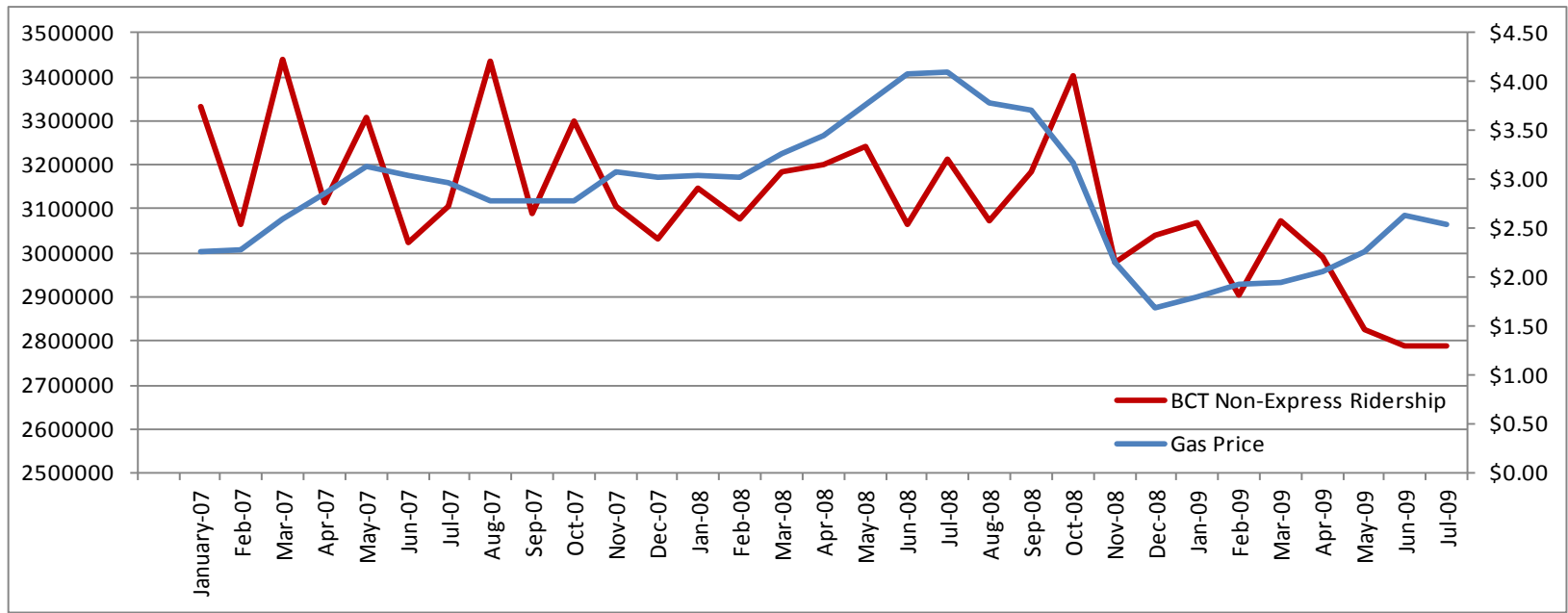

Figure 2-2: BCT non-express/local ridership and gas prices 2007-2009

\section{BCT Express Ridership}

For its amount of total ridership, BCT has relatively few express or limited stop lines in operation. This may be in part due to the dispersion of trip origins and destinations throughout the service area, even distribution of population density and congested roadways shared with local routes that don't have provisions for express service.

In September 2008, BCT launched the operation of Express Route 102. One month after its launch, total system express ridership nearly doubled from its low in February 2007. This spike was sustained even as gas prices dropped. The line was launched just shortly after peak gas prices and may have benefitted from the impact of those increased personal transportation costs for motorists.

The new express line may have drawn riders away from the underlying route on the University Drive corridor. It is unclear given these circumstances what impacts gas prices may have had on the October 2008 ridership highs, but it is clear that the drop in gas prices in the last quarter of 2008 did not result in a decrease in express ridership. In the 31 month study period, there does not appear to be much if any impact on BCT express ridership from gas prices. Identifying such a relationship is further complicated by a fare increase which has a proven negative effect on ridership. One point to note is that consistent with the literature, express ridership peaked 3 months after gas price peaks and local ridership had its third highest ridership month in October 2008 as well, suggesting if there were any impacts they occurred at the 3-month lag period after gas price highs. 


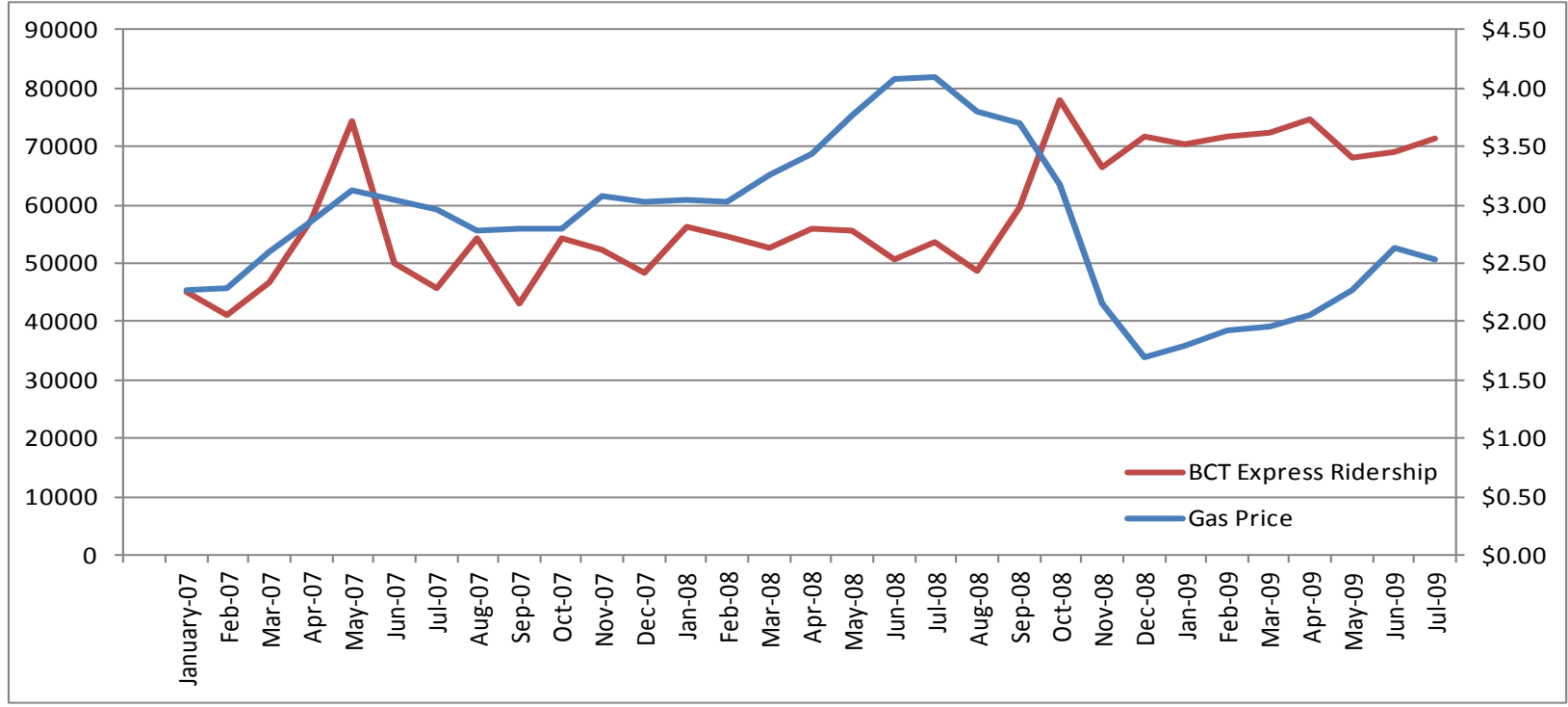

Figure 2-3: BCT express ridership and gas prices 2007-2009

\section{HART Non-Express/Local Ridership}

Figure 2-4 shows HART's local bus ridership has remained consistently stable over time, concluding with approximately the same number of monthly riders as the time period started with. Notable here is the spike in ridership experienced in October 2008, again reinforcing the notion of a 3-month lag to ridership spikes as found in Broward. Ridership dropped concurrently with the following drop in gas prices, yet not as dramatically as BCT or the $50 \%$ price decrease.

The second highest ridership period in the 31-month range is October 2007. So even though the year over year increase from October 2007 to 2008 is greater than 10\%, the fact is that for 2007 \& 2008, October is normally a high ridership month. There were no service changes in the July 2008 -October 2008 period that would have influenced this outcome.

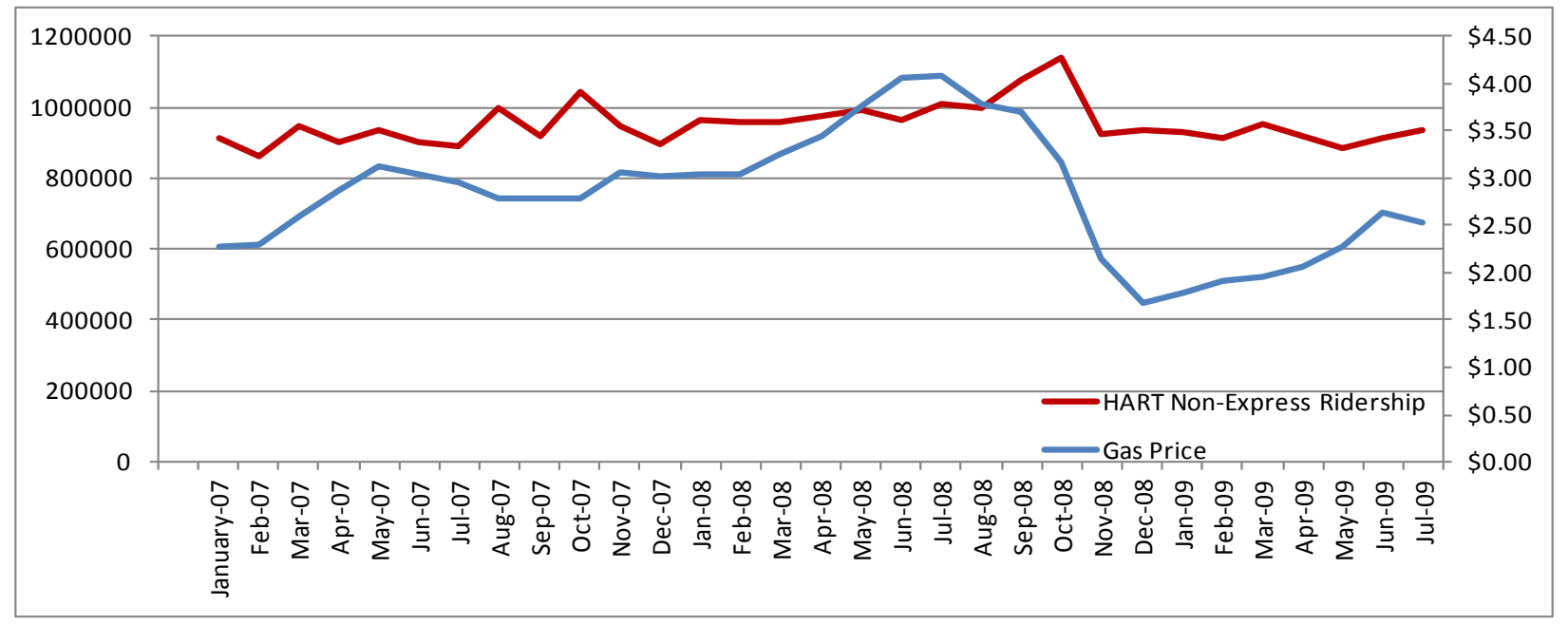

Figure 2-4: HART non-express/local ridership and gas prices 2007 - 2009 


\section{HART Express Ridership}

HART's express route ridership is another example with an October 2008 ridership peak (Figure 2-5). HART's well developed system of express routes, connecting suburban residential areas to the urban core, dropped nearly concurrently with the drop in gas prices but maintained a higher rate of ridership than at the window outset. This case illustrates the findings of the research exemplifying a 3-month lag, a somewhat asymmetrical rise and fall of ridership with maintenance of some ridership gains at the 12 month period after $\$ 4.00$ gas.

HART's express routes have few intermediate stops between the park and rides in the residential areas and urban downtown core. These services are primarily used by commuters and the geo-spatial analysis in the next section looked for any demographic trends in the highest ridership gaining routes during this period.

Unlike BCT, these data suggest there may be some influence that gas prices have had on ridership. One way to control for the amount of service provided is to normalize each service type using a productivity measure. Here, both local and express routes are again presented but with passengers per revenue hour and gas prices instead of total ridership.

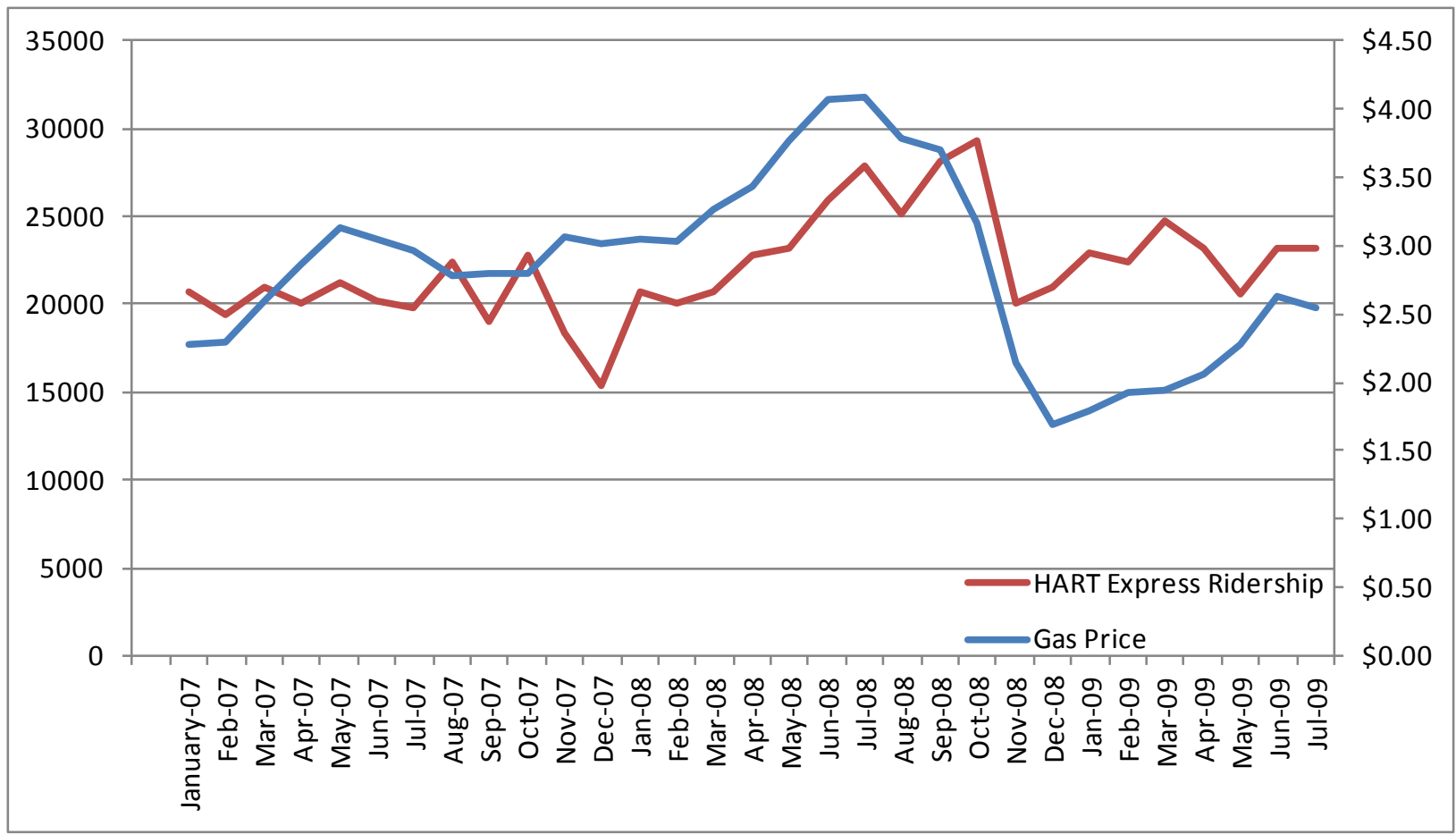

Figure 2-5: HART express ridership and gas prices $2007-2009$

\section{HART Non-Express/Local Passengers per Revenue Hour}

Normalizing productivity for HART local service still reveals the highest rates at the October 2008 benchmark, but depresses some of the post $\$ 4.00$ gas levels of activity from the total ridership example. In this case, it appears in order to maintain the ridership in the 12 months following $\$ 4.00$ gas, there were small but significant increases in the amount of 
service provided. This more accurately identifies that gas prices may have accounted for some ridership in the 3-month spike period after July 2008, but it is less clear that they influenced any maintenance of ridership in the subsequent 9 months. Passengers carried per revenue hour were at their lowest in the final 3 months of the analysis window, as shown in Figure 2-6.

Figure 2-6: HART non-express/local passengers per revenue hour and gas prices 20072009

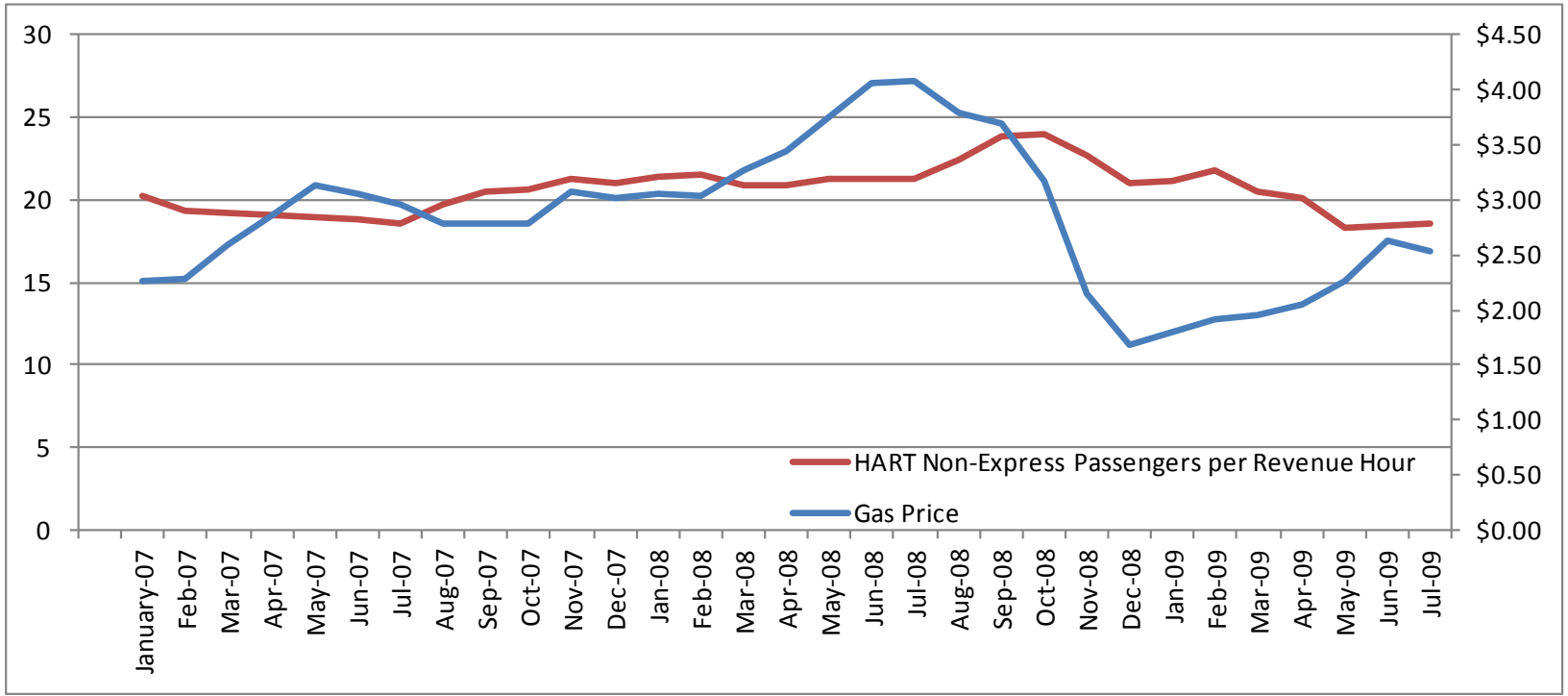

\section{Hillsborough Express Passengers per Revenue Hour}

HART's express routes, when normalized for the amount of service in operation, appeared to maintain some levels of ridership after gas prices dropped and other broader economic contraction took effect. Of the 4 cases (Broward local \& express/HART local \& express), HART express services may have been the most influenced by gas prices.

\section{Summary}

The analysis period was chosen to capture the escalation of gas price, its peak and the subsequent 12 months as shown in Figure 2-8 below. Beyond this timeframe, the rise in unemployment, cuts to service levels, and fare increases cannot be controlled for in the datasets.

In the 31-month analysis period (see Figure 2-7), local and express bus ridership hit their highest levels in both Broward and Hillsborough Counties in October 2008, approximately 3 months after the highest gas prices are reported. An exception is the October 2008 nonexpress ridership in Broward was at only it 3rd highest point during the analysis period. This relationship is somewhat complicated by a fare increase and service change undertaken by BCT in October 2008. 
Annually, transit ridership is relatively high in September and October. However, March is typically the highest ridership month for many of Florida's transit agencies.

When normalizing for service levels in Hillsborough County, both express and nonexpress/local ridership remained at their highest point in October 2008. As a metric, passengers per revenue hour were used to control for changes to service levels that came after the period of $\$ 4.00$ gas. This demonstrates that the maintenance of some ridership at HART that followed $\$ 4.00$ gas is not entirely attributable to service levels, suggesting more study should be done to control for other influencing variables.

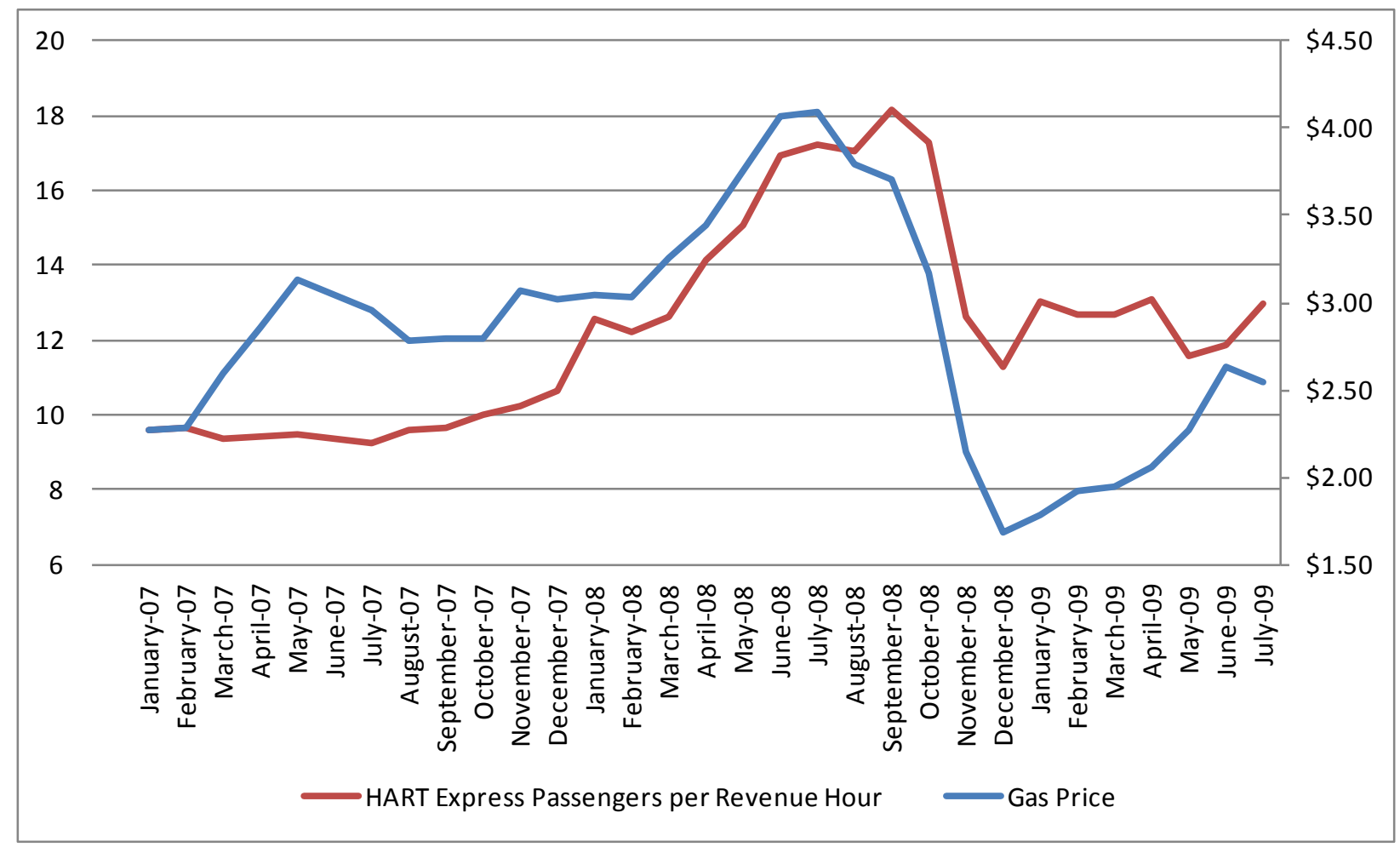

Figure 2-7: HART express passengers per revenue hour and gas prices 2007- 2009

\section{Geospatial Analysis}

Within the study period there were both significant ridership gains and losses. The research identified 3- and 12-month lags to effects, which were experienced in Hillsborough County. Conversely, $85 \%$ of Broward County's bus routes declined year over year after $\$ 4.00$ gas. 
Table 2-2: Routes in Hillsborough and Broward with ridership increases at 3- and 12-months subsequent to peak gas prices

\begin{tabular}{|c|c|c|}
\hline \multirow[t]{2}{*}{ STATISTICS } & \multicolumn{2}{|c|}{ ROUTES } \\
\hline & Broward & Hillsborough \\
\hline \multicolumn{3}{|c|}{3 MONTHS } \\
\hline $\begin{array}{l}\text { Total Routes in } \\
\text { Service }\end{array}$ & 42 & 46 \\
\hline Increase & 30 & 35 \\
\hline Decrease & 12 & 11 \\
\hline Max Increase & $20.86 \%$ & $30.19 \%$ \\
\hline \multicolumn{3}{|c|}{12 MONTHS } \\
\hline $\begin{array}{l}\text { Total Routes in } \\
\text { Service }\end{array}$ & 38 & 46 \\
\hline Increase & 6 & 25 \\
\hline Decrease & 32 & 21 \\
\hline Max Increase & $30.92 \%$ & $53.27 \%$ \\
\hline
\end{tabular}

It was not the intent of this analysis to attribute any specific amount of ridership to gas price increases, but instead to identify trends or features within the data that correspond to findings within prior research. Existing research suggests the following 5 measures may be associated with transit demand elasticities and it was the goal of this portion of the study to measure these variables within the census block groups adjoining the routes with the highest ridership increases during the times of high gas prices.

- Employment

- Mean travel time to work

- Average number of Household Vehicles Available

- Percentage of Zero Vehicle Households

- Total Cost of Transportation as a Percentage of Median Household Income

The census block group averages of these 5 measures were compared between; those block groups adjacent to the routes with the highest ridership gains at 3 and 12 months post$\$ 4.00$ retail gas price, and the service area in total. Any significant variance from the block groups surrounding high performing routes and the service-area-wide averages was noted.

For purposes of the geo-spatial comparison, June and September 2008 were chosen as each were 30 day months with 21 weekdays. Data sources included route ridership and historical service changes from the two transit agencies, the U.S. Census Bureau's American Community Survey (ACS) and the Environmental Systems Research Institute (ESRI).

Only routes that exceeded a 5\% increase in September 2008 over June 2008 (when prices exceeded $\$ 4.00$ nationally) were included in the figures to discount any seasonal influence in the ridership totals. 


\section{Broward County 3-Month Ridership}

At the 3-month mark of the post $\$ 4.00$ gas price threshold, the majority of census blocks in the BCT service area adjoined transit routes with a greater than $5 \%$ increase in ridership. Service areas that did not adjoin high performing transit routes were found within the southwest and south central county, northwestern county and along the coast in the northeast. These western areas where increases were not realized are primarily residential. It would be expected that if gas prices were driving the increases in ridership, the longer trip lengths and commute patterns from those areas would increase sensitivity to gas prices and lead to higher demand. At three months, that doesn't appear to be case and may be attributable to the quality of service found there.

A review of the five measures for the census blocks adjoining high increased transit ridership routes also did not indicate any more sensitivity than that of the service area as a whole (see Figure 2-8). One measure, percent of zero car households by census block, performed as expected geographically for high ridership routes versus the county as a whole because zero car households are likely to be less elastic with respect to transit demand. Aside from this metric, there was little separating the high transit demand census blocks from the rest of the service area and this map provided another indication BCT's local ridership is not elastic, or influenced by gas prices. The small number of premium transit options for the discretionary user may simply not allow for many drivers to effectively switch modes onto BCT's service. 


\section{Effectively Managing Consumer Fuel Price Driven Transit Demand}

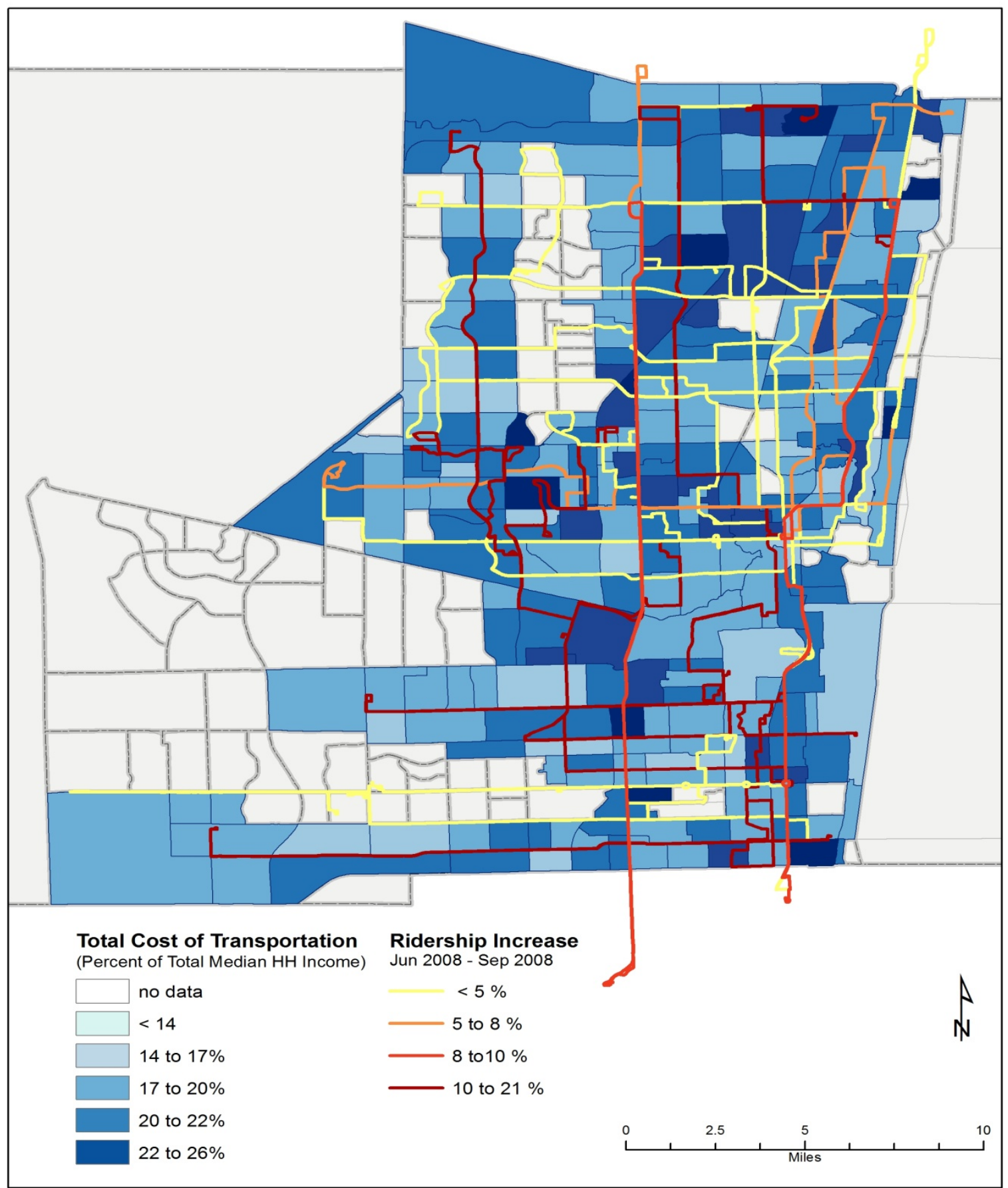

\begin{tabular}{|c|c|c|c|c|c|}
\hline & Unemployment & Mean Travel Time to Work & Veh Avail & HH with O Veh & Transp Cost \\
\hline & (\%) & $(\min )$ & (per HH) & $(\%)$ & (\%) \\
\hline Broward County & 9 & 26.4 & 1.3 & 3.8 & 17.3 \\
\hline 3 month ridership increases & 9.3 & 26.7 & 1.3 & 4.6 & 16.7 \\
\hline
\end{tabular}

Figure 2-8: BCT routes with increases at 3-month post $\$ 4.00$ gas 


\section{Broward County 12-Month Ridership}

Year over year figures for June were provided to identify any routes that may have sustained ridership increases and what, if any demographic trends may have existed within the adjoining census block groups. Due to the fact year over year data is being used, the threshold to include a bus route is reduced from more than $5 \%$ to account for seasonal variation, to anything above $0 \%$. One year later, only $15 \%$ of BCT bus routes had any ridership gains from June 2008. As previously discussed, a rise in unemployment and other economic uncertainties depressed both VMT and transit use during this time. A fare increase had also been in effect for the previous 9 months.

Three routes in the southern end of the county all had increases above $10 \%$ year over year (see Figure 2-9), while three other routes which extended into the northern part of the county had increases up to $10 \%$. Evaluating the much smaller subset of census block data which surround the six increased ridership routes do not offer any additional insight into factors which may have contributed to those increases. There continued to be a higher number of zero car households along the increased ridership routes. This may be explained by the service area not extending into the most suburban or exurban areas of the county, where zero car households are at their lowest amount. This metric, as well as the low mean travel time to work value, suggested the gains in ridership for these routes may not have been attributable to gas prices. There were also no substantial increases in service levels on these lines in the previous year to explain the ridership improvements. 


\section{Effectively Managing Consumer Fuel Price Driven Transit Demand}

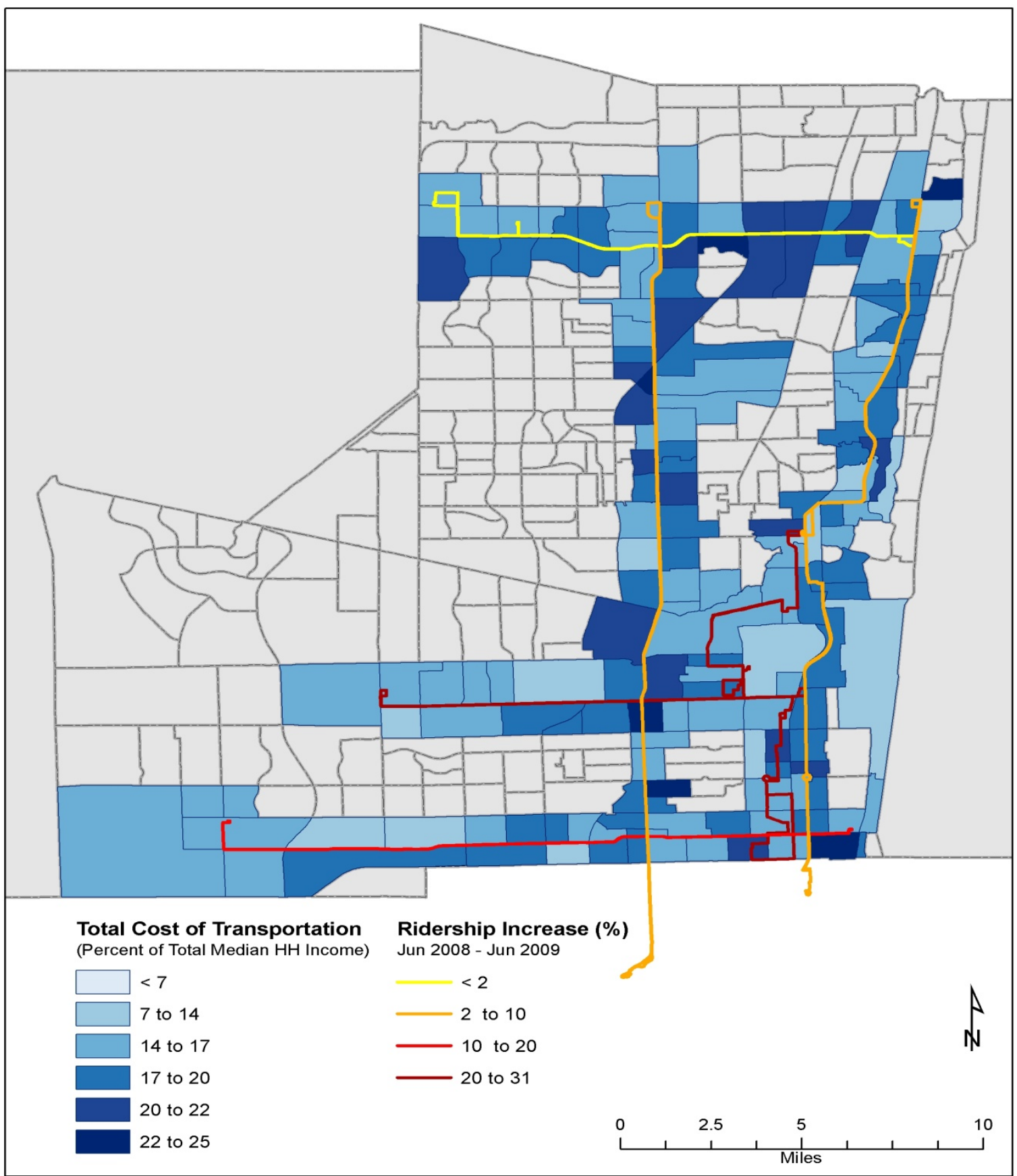

\begin{tabular}{|l|c|r|r|r|r|}
\hline & Unemployment & Mean Travel Time to Work & Veh Avail & HH with O Veh & Transp Cost \\
\hline & (\%) & (min) & (per HH) & (\%) & \multicolumn{2}{|c|}{ (\%) } \\
\hline Broward County & 9 & 26.4 & 1.3 & 3.8 & 17.3 \\
\hline 12 Month Increases & 9.5 & 26.1 & 1.3 & 4.7 & 17.2 \\
\hline
\end{tabular}

Figure 2-9: BCT routes with increases at 12-months post $\$ 4.00$ gas 


\section{Effectively Managing Consumer Fuel Price Driven Transit Demand}

\section{HART 3-Month Ridership}

Three months after $\$ 4.00$ gas prices, more than $75 \%$ of HART bus routes experienced ridership gains in excess of $5 \%$. This resulted in almost the entire service area being included in the census block group subset of the total county values for the 5 variables. When comparing this subset to larger County values, it is difficult to separate out what factors may be of influence. Therefore, more detailed analysis is done by service type (nonexpress/express) and included the highest increases found in the top 10-15\% of all routes. 


\section{Effectively Managing Consumer Fuel Price Driven Transit Demand}

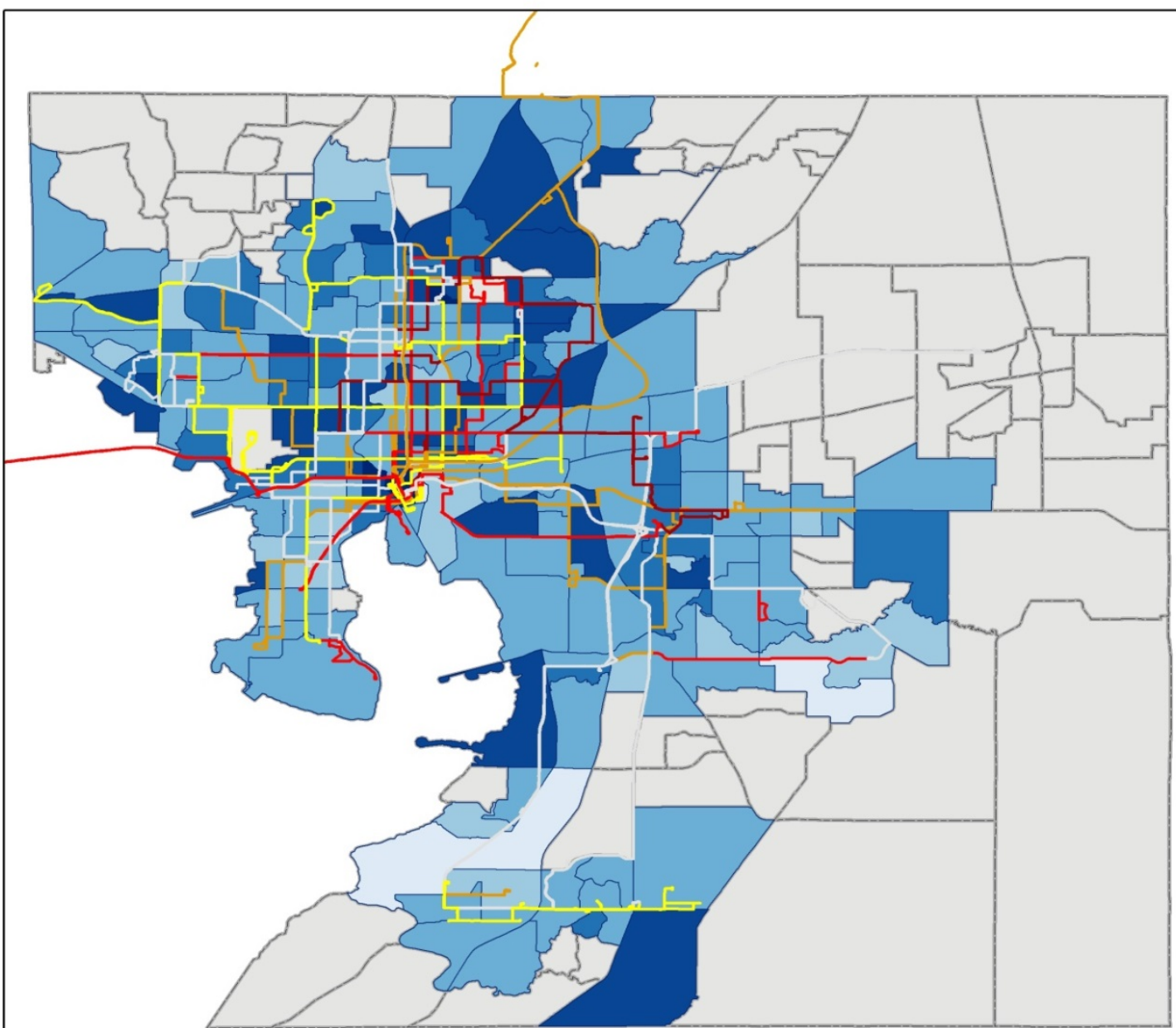

Total Cost of Transportation (Percent of Total Median HH Income)

Ridership Increase (\%)

$\square<11$

Jun 2008 - Sep 2008

$<5$

11 to 14

5 to 9

14 to 19

9 to 15

19 to 22

15 to 22

22 to 30

30 to 50

\section{2 to 30}

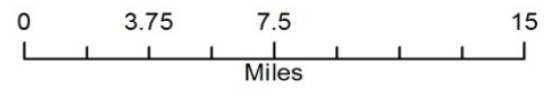

\begin{tabular}{|l|r|r|r|r|r|}
\hline & Unemployment & Mean Travel Time to Work & Veh Avail & HH with 0 Veh & \multicolumn{1}{c|}{ Trans Cost } \\
\hline & $(\%)$ & $(\mathrm{min})$ & $(\mathrm{per} \mathrm{HH})$ & $(\%)$ & $(\%)$ \\
\hline Hillsborough County & 9.1 & 25.4 & 1.2 & 4.8 & 18.2 \\
\hline 3 month increases & 9.6 & 24.1 & 1.2 & 4.1 & 18.4 \\
\hline
\end{tabular}

Figure 2-10: All HART routes with increases at 3-months post $\$ 4.00$ gas 


\section{HART 3-Month Local/Non-Express Ridership}

Three local bus routes experienced ridership growth from $20 \%$ to $30 \%$ three months after $\$ 4.00$ gas prices. Routes 9,37 and 57 all share geographic proximity in the east/northeast portion of the service area and each of the three routes shares at least one transfer location with one of the other high ridership routes. Major trip generators on these routes include downtown Tampa, the University of South Florida main campus and the Netpark call center, an employment hub.

All three routes had adjoining census block group averages that exceed the mean total cost of transportation as a percentage of household income levels. All three routes have mean travel times to work below countywide averages, which discounted the potential cost savings from gasoline from switching from another mode of travel to transit for commute trips.

Zero car households and number of average vehicles per household were not consistent among all routes, diminishing what influence those factors may have had on the increased ridership levels. Contrary to what the literature suggested, income levels along these three high ridership routes are below countywide averages. However, the total cost of transportation in several of the census block groups was somewhat high. These results were mixed in supporting the profile of a highly gas price sensitive constituency. In total, the sheer volume of increased ridership in such a short time period suggests some external factors may have driven the higher ridership. Due to the lack of demographic consistency along the routes but geographic concentration of the gains, they may be better explained by conditions local to this area rather than the countywide impact of gas prices. Urban form may play a greater role in the gas price and transit demand relationship than demographics do in this example. 


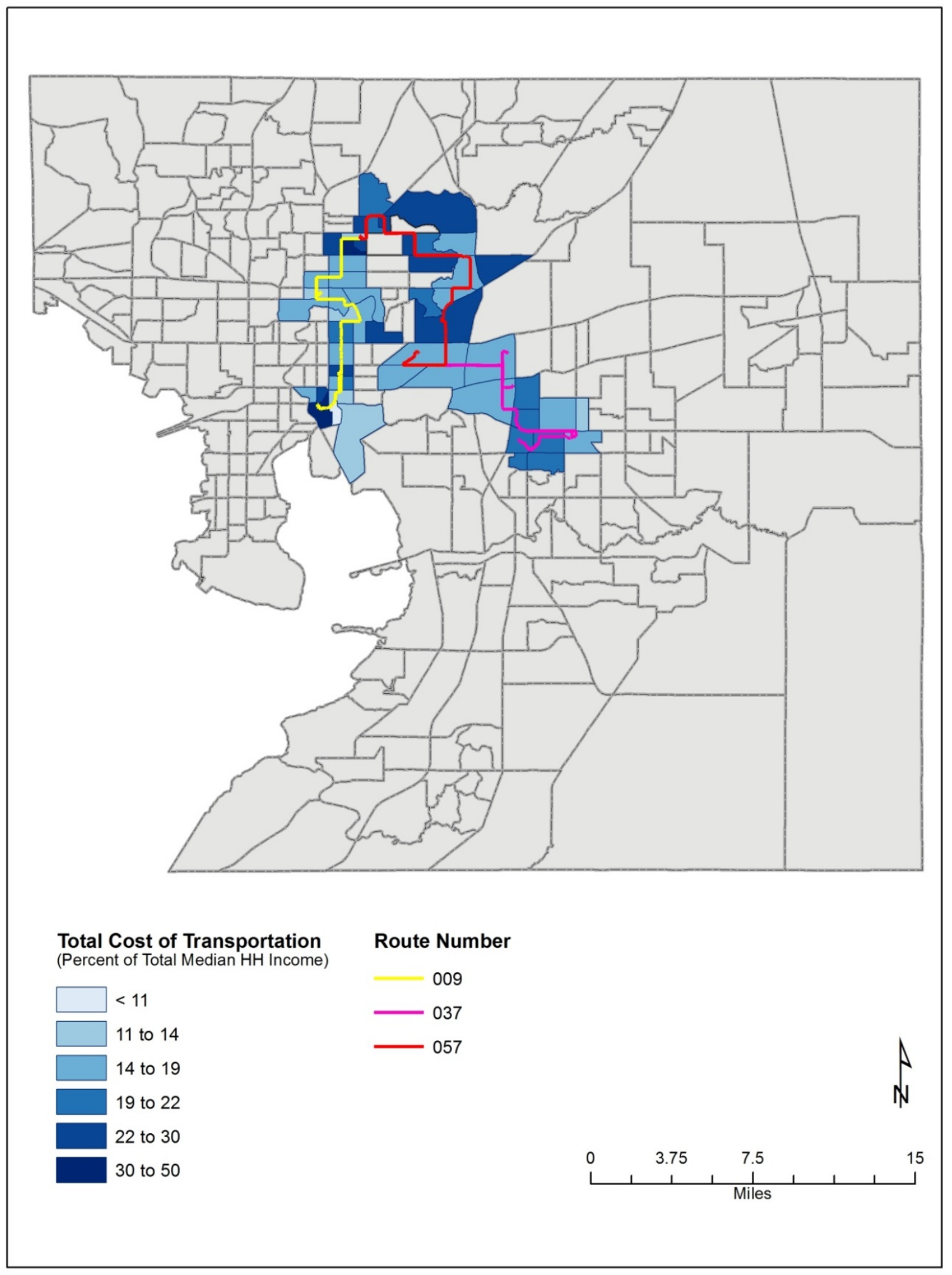

Figure 2-11: HART local routes with increases at 3-months post $\$ 4.00$ gas 
Table 2-3: Hillsborough County averages

\begin{tabular}{|c|c|c|c|c|c|c|}
\hline & $\begin{array}{c}\text { Unemployment } \\
{[\%]}\end{array}$ & $\begin{array}{c}\text { Mean Travel } \\
\text { Time to } \\
\text { Work }[\mathrm{min}]\end{array}$ & $\begin{array}{c}\text { Available } \\
\text { Vehicles } \\
\text { [per HH] }\end{array}$ & $\begin{array}{c}\text { Transportation } \\
\text { Cost [\%] }\end{array}$ & $\begin{array}{c}\text { Households } \\
\text { with } 0 \text { Vehicle } \\
{[\%]}\end{array}$ & $\begin{array}{c}\text { Income } \\
(\$)\end{array}$ \\
\hline Hillsborough (Avg) & 9.1 & 25.4 & 1.2 & 18.2 & 4.8 & 53,090 \\
\hline \multicolumn{7}{|l|}{ Bus Route } \\
\hline 9 & 14.3 & 23.3 & 1 & 20.1 & 7.2 & 33,506 \\
\hline 37 & 7.6 & 21.2 & 1.3 & 20.9 & 4.3 & 46,991 \\
\hline 57 & 12.5 & 23 & 1.2 & 19.9 & 4.1 & 35,862 \\
\hline
\end{tabular}




\section{HART 3-Month Express Ridership}

Four express bus routes experienced ridership growth of $10 \%$ or greater three months after $\$ 4.00$ gas prices, as shown in Figure 2-12 and Table 2-4. Routes 22, 24 and 25 connect the eastern suburban areas to downtown Tampa and the MacDill Air Force Base. Route 51 connects an adjacent county Park $\mathrm{n}$ Ride and the northern Hillsborough county residential base with downtown. Only those census blocks selected were within the high ridership route subset that contained locations where boardings onto the routes could occur (with the exception of the return trips from the employment centers).

Using this methodology, certain variables begin to stand out.

- All 11 census blocks had better employment numbers than the countywide average (one did not report data).

- 10 of the 11 census blocks that reported data had the average number of zero car households far below the countywide average

- All 11 census blocks that reported data had mean travel times to work that exceeded the county average

These factors are consistent with the research that suggests gas prices are most likely to solicit a switch from single occupancy auto to transit where there is good transit access, long trip lengths make the switch cost-effective to make, commute trips are prevalent and rail and other premium transit options are available. HART's express bus lines are the most rail-like in the network.

Two factors, total cost of transportation and number of household vehicles, did not trend away from countywide averages and appear not to be of influence. Unlike the local service routes income levels, express ridership average incomes were considerably higher. This was supportive of the profile put forward by the literature as a gas price sensitive demographic feature. 


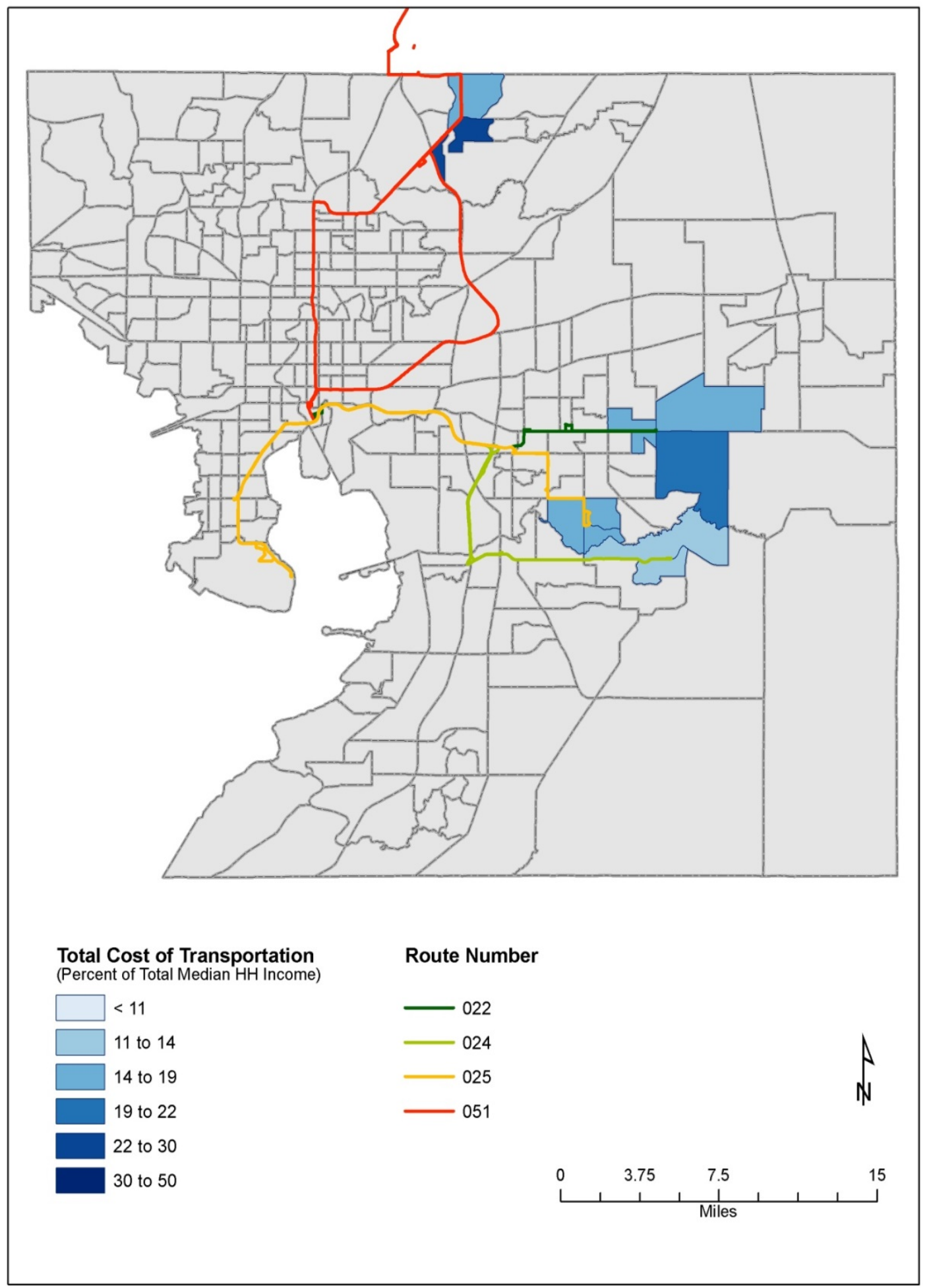

Figure 2-12: Hart express routes with increases at 3-months post $\$ 4.00$ gas 
Table 2-4: Hillsborough County averages

\begin{tabular}{|c|c|c|c|c|c|c|c|}
\hline & & $\begin{array}{c}\text { Unemployment } \\
{[\%]}\end{array}$ & $\begin{array}{c}\text { Mean Travel } \\
\text { Time to Work } \\
{[\text { min] }}\end{array}$ & $\begin{array}{c}\begin{array}{c}\text { Available } \\
\text { Vehicles }\end{array} \\
\text { [per HH] }\end{array}$ & $\begin{array}{c}\text { Transportation } \\
\text { Cost } \\
{[\%]}\end{array}$ & $\begin{array}{c}\begin{array}{c}\text { Households } \\
\text { with O Vehicle }\end{array} \\
{[\%]}\end{array}$ & $\begin{array}{c}\text { Income } \\
{[\$]}\end{array}$ \\
\hline \multicolumn{2}{|c|}{ Hillsborough } & 9.1 & 25.4 & 1.2 & 18.2 & 4.8 & 53,090 \\
\hline $\begin{array}{l}\text { Bus } \\
\text { Route }\end{array}$ & $\begin{array}{l}\text { Census Block } \\
\text { Groups }\end{array}$ & & & & & & \\
\hline \multirow{5}{*}{22} & 12057012210 & 7.9 & 25.9 & 0.91 & 15.68 & 0 & 43,081 \\
\hline & 12057013204 & 7.1 & 28.8 & 0.81 & 15.91 & 1.4 & 44,025 \\
\hline & 12057012403 & 7.9 & 23.3 & 1.3 & 17.69 & 1.6 & 44,949 \\
\hline & 12057013207 & 6 & 30.4 & 1.45 & 19.57 & 0 & 64,828 \\
\hline & average & 7.22 & 27.1 & 1.12 & 17.21 & 0.75 & 49,220 \\
\hline \multirow{3}{*}{24} & 12057013921 & 2.1 & 31.7 & 1.7 & 13 & 0 & 117,025 \\
\hline & 12057013922 & 2.6 & 35.2 & 1.5 & 12.05 & 0.3 & 89,583 \\
\hline & average & 2.35 & 33.45 & 1.6 & 12.53 & 0.15 & 103,304 \\
\hline \multirow{4}{*}{25} & 12057013407 & 7.9 & 30.2 & 1.54 & 18.2 & 0 & 75,313 \\
\hline & 12057013414 & 7.1 & 31.9 & 1.56 & 15.99 & 0.5 & 86,975 \\
\hline & 12057013415 & 2.4 & 33.8 & 1.64 & 14.95 & 4.5 & 98,724 \\
\hline & average & 5.8 & 32 & 1.58 & 16.38 & 1.6 & 87,004 \\
\hline \multirow{4}{*}{51} & 12057011014 & No data & No data & 1.62 & 18.75 & 5.2 & 59,583 \\
\hline & 12057010205 & 9 & 31.7 & 1.39 & 16.16 & 0 & 84,639 \\
\hline & 12057010211 & 7.3 & 31.7 & 1.32 & 22.45 & 3 & 68,818 \\
\hline & average & 8.15 & 31.7 & 1.44 & 19.2 & 2.7 & 71,013 \\
\hline
\end{tabular}




\section{HART 12-Month Ridership}

More than half of all of HART's bus routes maintained ridership gains 12 months after the first occurrence of $\$ 4.00$ gas. The highest ridership maintenance from the previous 12 months was for east-west routes which connect the suburban communities to both downtown and the MacDill Air Force Base in South Tampa. One route that connects the airport and downtown transfer center maintained high increases in ridership. That route, \#30, had a significant increase in frequency and was supplied nearly twice the amount of service as a year prior. It is notable that the cross bay route that connects two major cities with a long trip length, maintained high ridership increases a year after $\$ 4.00$ gas prices, shown in Figure 2-13. 


\section{Effectively Managing Consumer Fuel Price Driven Transit Demand}

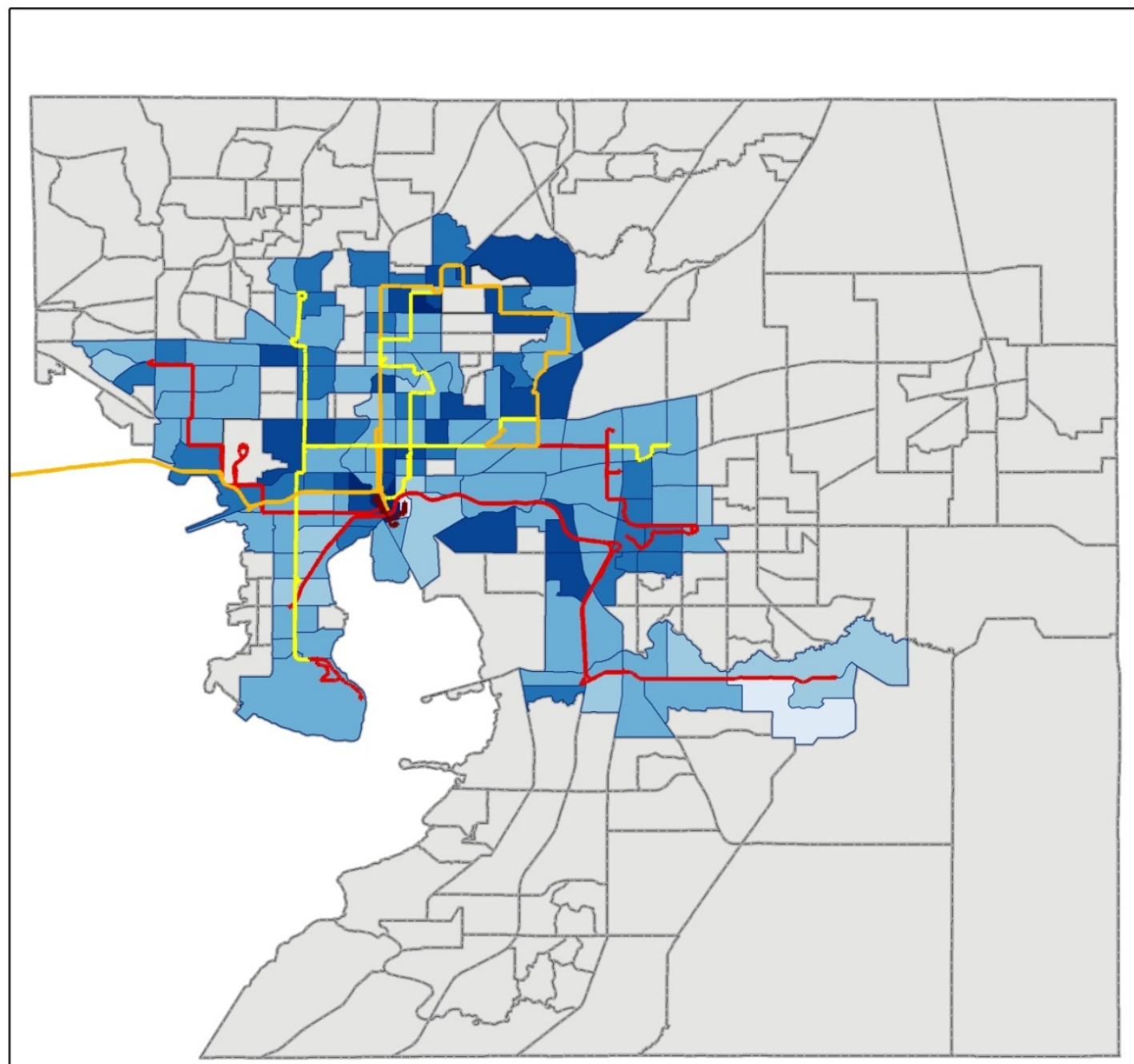

Total Cost of Transportation

(Percent of Total Median HH Income)

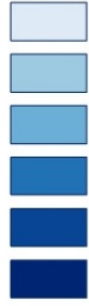

$<11$

11 to 14

14 to 19

19 to 22

22 to 30

30 to 50
Ridership Increase (\%)

June 2008 - June 2009

$<2$

2 to 10

- 10 to 20

20 to 53
$N_{N}$

$\stackrel{9.5}{1}, \quad, \quad 19$

0 4.7

\begin{tabular}{|c|c|c|c|c|c|}
\hline & Unemployment & Mean Travel Time to Work & Veh Avail & Trans Cost & HH with 0 Veh \\
\hline & $(\%)$ & $(\mathrm{min})$ & $($ per $\mathrm{HH})$ & $(\%)$ & $(\%)$ \\
\hline Hillsborough County & 9.1 .10 & 25.4 & 1.2 & 18.2 & 4.8 \\
\hline 12 Month Increases & 10.3 & 23.1 & 1.2 & 18.5 & 4.8 \\
\hline
\end{tabular}

Figure 2-13: HART routes with increases at 12-months post $\$ 4.00$ gas 


\section{Effectively Managing Consumer Fuel Price Driven Transit Demand}

\section{Limitations}

The methodology used in this analysis of both service providers possessed limitations that prevented a more clear understanding of the gas price and transit demand relationship.

Three months after $\$ 4.00$ gas peaked, the majority of routes had significant increases in ridership, and there was little distinction between census block groups within .25 mile of high increase routes from those that were not. This prevented any meaningful separation between the two groups that could demonstrate any influence of the five variables. In the future, this may be addressed through the use of smaller geographies, such as census tracts, that were not available in 2008 for these datasets.

At 12 months post- $\$ 4.00$ gas price, several mitigating circumstances were considered to have negatively impacted ridership in Broward County. Some of these could be accounted for through the use of productivity ratios. However, service cuts, unemployment and fare increases all impacted demand and likely affected ridership levels at 12 months.

Express bus routes traveled through block groups where the bus does not actually stop to board or alight passengers. These types of routes were found in the HART bus network and were controlled for by not including block groups in the averages where the bus does not stop.

\section{Conclusions}

The geospatial analysis largely discounted the impact that any one of the five variables on transit usage for non-express/local service. The time period chosen for the study maximized the likelihood that the price of retail gasoline could have been a contributing factor to the increases in ridership that were experienced between at both systems.

The HART 3-month ridership improvement on the express bus routes showed the possibility of the following variables being of influence when gas prices were high, consistent with existing research:

- Higher levels of employment than service-area-wide averages

- Longer average travel time to work than service-area-wide averages

- Significantly lower numbers of households with zero vehicles available than servicearea-wide averages

There were no trends in the data at 12 months for either system that demonstrated any consistent effect of the five variables. This timeframe is particularly difficult to isolate because of fare increases, service changes, and economic conditions.

Comparatively, perhaps Hillsborough saw greater and longer lasting increases in ridership due to latent demand. Broward was already operating as the more productive service. Perhaps, BCT levels of ridership could only marginally improve compared to Hillsborough. It may also be the case that the urban form of the HART service area, with greater separation between the urban and suburban areas, was more affected by gas prices than the more dense and evenly distributed urbanization of Broward County. 


\section{Chapter 3}

\section{Transit Service Stress Points}

The literature review included multiple studies that considered different transit modes and the impacts gas prices have on the demand for those services. These were typically focused on mid to large urban areas with a differentiation for a variety of rail types (heavy, light, commuter) but very little distinction among bus-type services such as express, Bus Rapid Transit (BRT), local, or neighborhood circulator as examples. There are however, findings from the literature search which could provide clues into how demand for those bus oriented services are affected when gas prices increase.

First, a distinction is made between demand for rail and bus services as summarized from the case studies and other relevant findings from the research:

- 3 studies included commuter rail and found one elasticity of 0.27

- 4 studies included heavy rail and found a range of elasticities from 0.17 to 0.26

- 4 studies included light rail and found a range of elasticities from 0.06 to 0.38

- 5 studies included bus and found a range of elasticities from 0.04 to 0.24

The studies consistently find that rail is more elastic with respect to gas prices than bus. High rail elasticities may be attributable to the following:

- Longer average trip lengths for rail versus bus can result in cost savings making the switch more viable financially

- Rail is more likely to be found in areas with better service quality, providing more attractive options for those considering using transit. There are a higher number of alternatives to auto use in rail catchment areas than in bus service areas

The elasticities are also supported in the case studies that measured both modes. For example, a study of the Southeastern Pennsylvania Transportation Authority found that in times of high gas prices, regional rail patronage increased twice as much as did bus patronage. Tri-Rail, a Florida commuter rail system, increased service from 2006 to 2007, then carried 4,303,509 passengers in 2008, representing a 22.9 percent increase over the 2007 total of 3,501,704 passengers. Figure 3-1 shows that in the fall of 2008, when gas prices dropped from $\$ 4.00$ per gallon, many transit systems, including Tri-Rail recorded their highest passenger counts. Tri-Rail reported its highest ridership of 400,808 in October 2008. As gas prices leveled off, a service cut was enacted coupled with a $25 \%$ fare increase and there was a dip in ridership in the summer of 2009. 


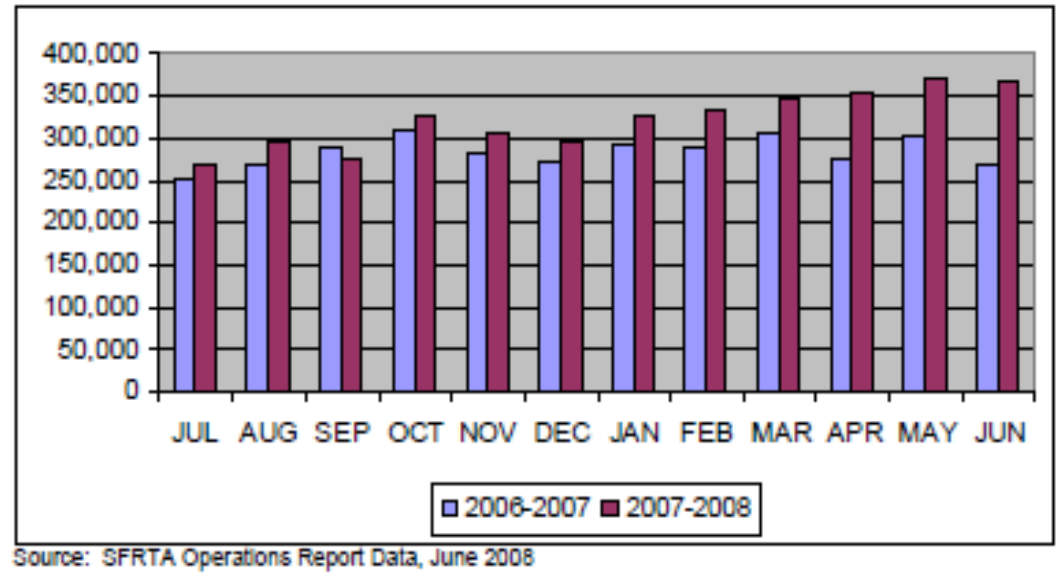

Figure 3-1: Tri-Rail ridership FY 2006 \& 2007

Different types of bus service have been aggregated into a single 'bus' category in all of the studies reviewed for this literature search. This should not be considered atypical, as the majority of bus service is composed of the local, core network characterized by slower speeds, shorter trip lengths and different markets served than rail. Bus services run a spectrum from those with 'rail-like' characteristics such as Bus Rapid Transit (BRT) and express with limited stops to local, urban and suburban circulators. Transit operators may operate some, all, or none of these service types.

\section{What Stress Points May Transit Operators Find in Their Family of Services When Gas Prices Increase?}

\section{Rail-Like Services: BRT and Express Routes}

BRT and express services serve similar markets to rail. BRT is considered a premium transit service. It is often operated in dedicated travel lanes with traffic signal priority to extend green light time or shorten red light time. BRT stations are well developed with many features similar to rail stations.

A review of the BRT services with dedicated lanes explains why these services may be more in demand by those who may not ride transit, typically only when gas prices go up. Enhanced service attributes such as span, frequency and reliability, comfort and safety are improved over local bus, and therefore more likely to succeed in attracting the discretionary market segment or, people that could ride transit but choose to travel private auto. Dedicated lane BRT is a bus service that could be considered in some ways comparable to rail travel.

A review of mixed traffic BRT, like the Los Angeles Metro Rapid, also finds higher ratings than the local bus system, despite that both make use of the same mixed traffic running way. Differences were found in relation to travel time, followed by frequency and reliability. Mixed traffic BRT is typically perceived as the high-performance version of the regular bus network, yet not as desirable as dedicated right of way BRT. ${ }^{70}$ 


\section{Effectively Managing Consumer Fuel Price Driven Transit Demand}

Express services can act much like rail, connecting centralized locations in the suburban periphery of the service area via park $\mathrm{n}$ rides or other high activity locations, to destinations in central business districts or other employment centers. Unlike BRT, they typically operate within mixed traffic subject to the same congestion as private automobiles. Expresses generally make fewer stops between their point of origin and final destination, lowering total travel time. Express services may run a limited number of trips during the morning and afternoon peak periods and target commuters as potential rider markets.

The analysis of HART in Tampa demonstrated the potential for express service to be increasingly demanded as fuel prices rise. Compared to the local service network, express routes can more reasonably replace auto commute trips and therefore be more sensitive to price fluctuations.

Both BRT and express would likely have elasticities comparable to the high end of the bus range or low end of the rail range. Investments in those services would make good candidates as ways to increase ridership when gas prices increase.

\section{Local Weekday and Weekend Bus Networks}

Local service has been addressed in the elasticities published in studies and in the closer look at two systems in Chapter 2. Elasticities, where they are found to be statistically significant, are low, as local service's primary market is the transit-dependent population which has few travel alternatives.

Palm Tran, the transit service for Palm Beach County Florida, operates a bus only system in a mid-sized urban area with no express services. An observation of Palm Tran's ridership in 2007 through 2009 is broken into weekday and weekend service to determine if the low bus elasticity might be diluted when commute travel (weekday peak) is mixed with leisure travel (off-peak, weekend).

Figure 3-2 shows Palm Tran's weekday ridership peaked in much of the same way ridership reacted nationally in response to $\$ 4.00$ per gallon gas. October and November 2008 were the two highest months in the same 31 month range used for the Chapter 2 analysis. 


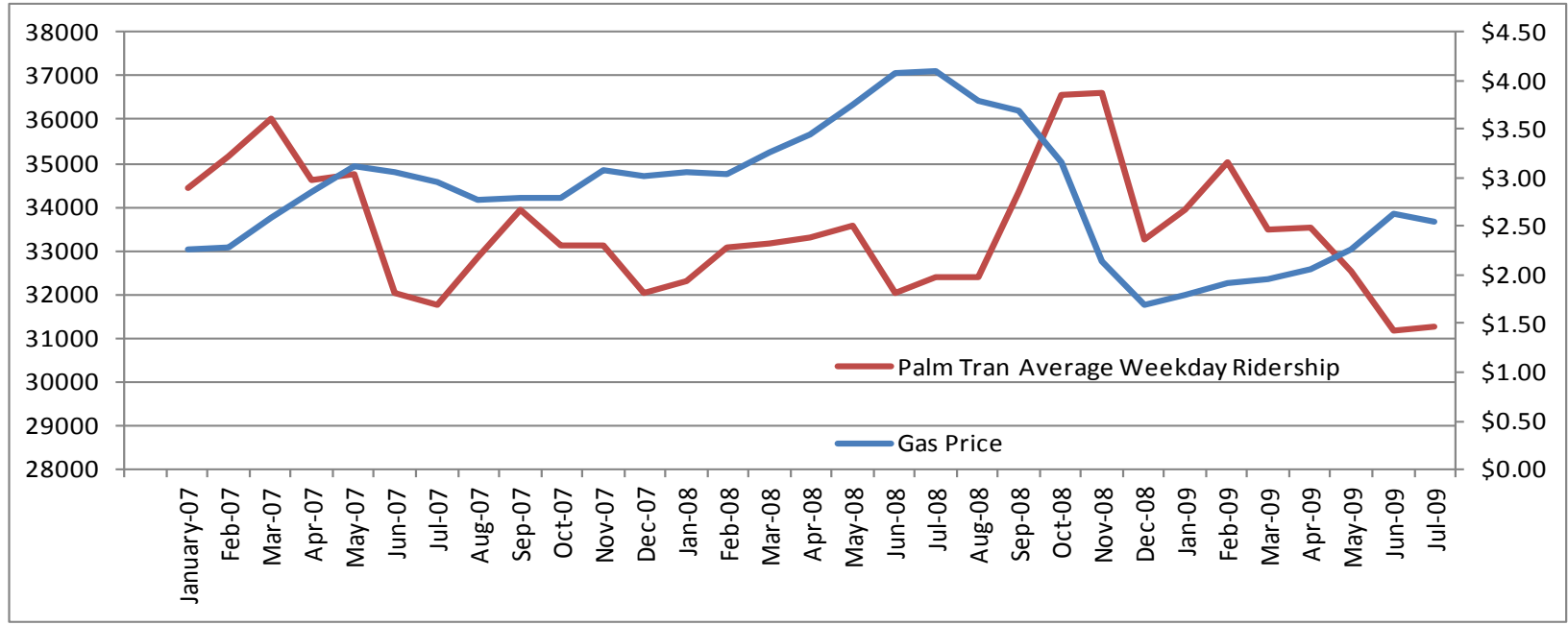

Figure 3-2: Palm Tran average Weekday ridership

Palm Tran's Saturday ridership does not appear in any way to be influenced by the price of gas when looking at Figure 3-3. A service cut in 2007 lowered the total number of riders from peaks early in that year.

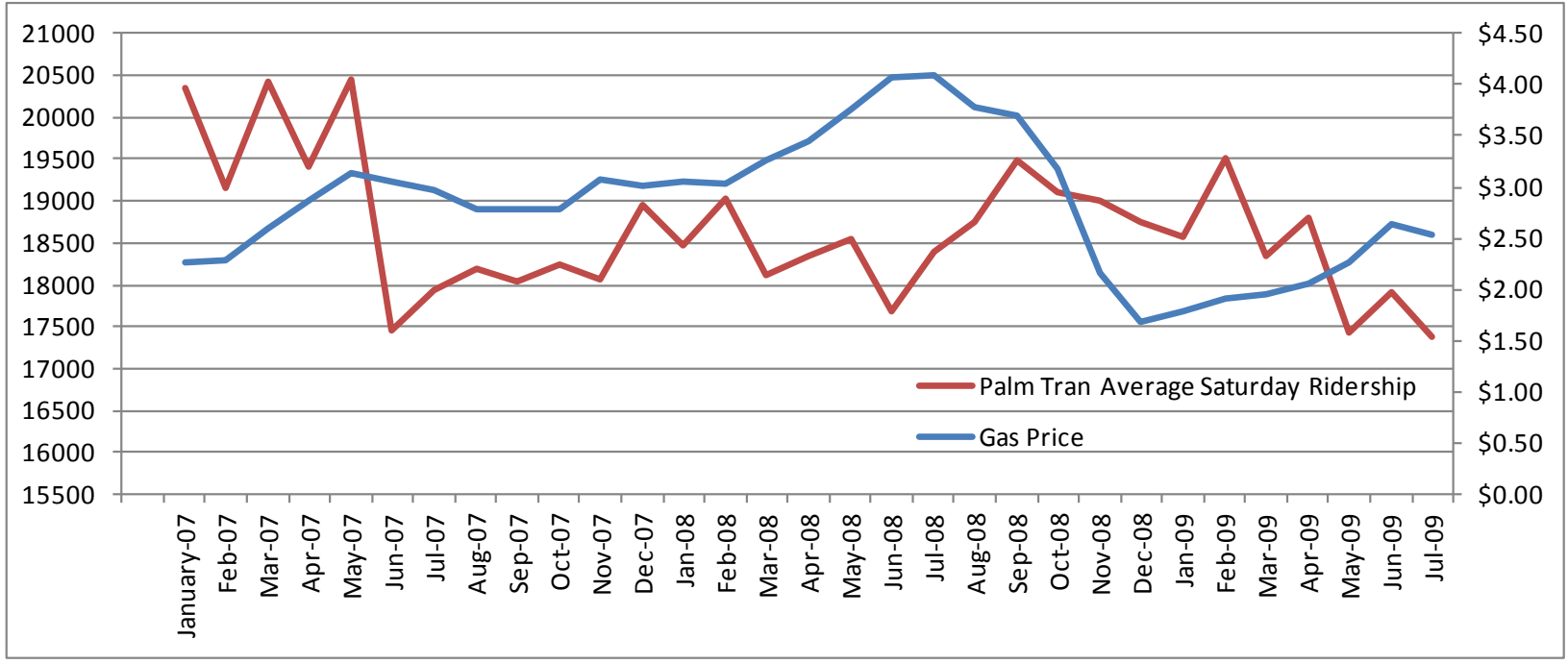

Figure 3-3: Palm Tran average Saturday ridership

Palm Tran Sunday ridership was flat following the service cut in 2007. The relatively low Sunday ridership provides for an easier opportunity to identify spikes or dips. Again, weekend ridership does not appear responsive to gas prices, as shown in Figure 3-4. 


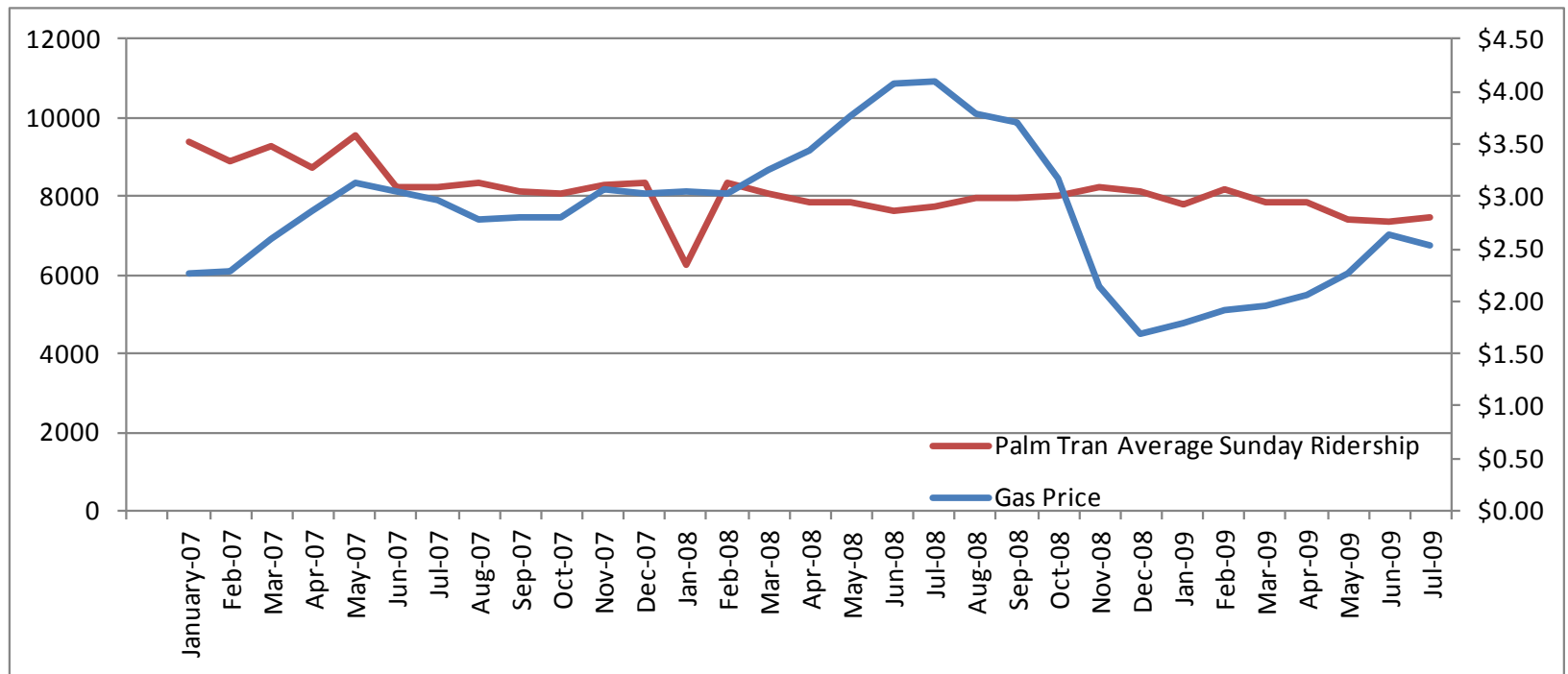

Figure 3-4: Palm Tran average Sunday ridership

When normalizing the data for weekday level of service, a small but noticeable bump in productivity is seen beyond 3 months after peaking gas prices. Based on the previous examples, that increase represents weekday ridership which is approximately $85 \%$ of total ridership.

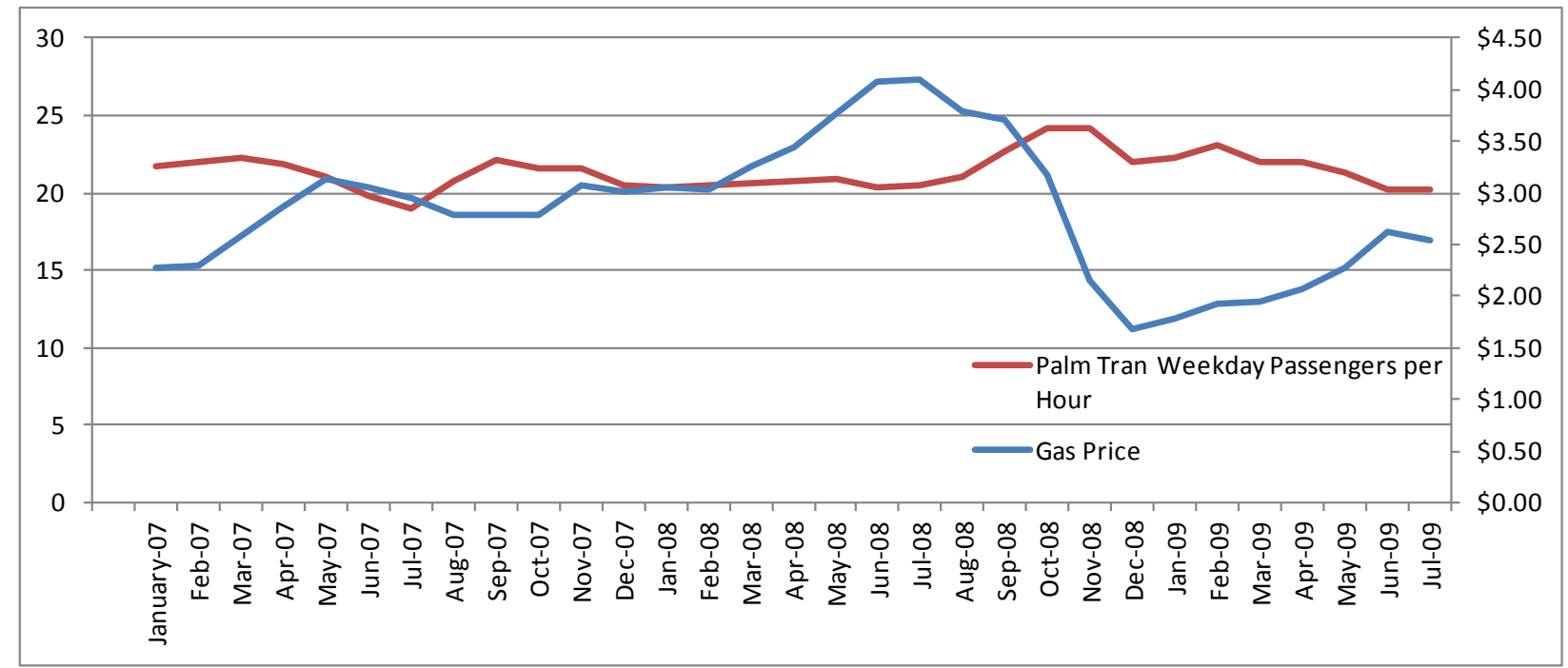

Figure 3-5: Palm Tran Weekday Passengers per hour

This provides only one example with limited context but demonstrates the expected relationship based on findings from the literature. Weekend local bus service is a small percentage of total ridership but does not demonstrate the same sensitivity to gas prices thought to be attributed to commute trips. BRT and express services have limited, service operating outside of weekdays in many cases. Despite the low overall elasticity of local bus 
service, targeted investments on weekday lines serving employment centers and residential origins may yield ridership increases.

\section{Urban Circulators}

The FTA defines urban circulator systems as streetcars and rubber-tire trolley lines which connect urban destinations and foster the redevelopment of urban spaces into walkable mixed use, high density environments. Typically, an urban circulator operates regular service within a closed loop, usually 3 miles or shorter in length, and serves an urban area; examples are the Portland Streetcar, the Denver 16th Street shuttle bus or the Lynx LYMMO in Orlando, which is a bus-based fixed guideway mode. ${ }^{71}$ No previous research was identified that studied the demand for urban circulators with respect to gas prices. A look at a few urban circulators may provide insight.

In Washington, D.C., the DC Circulator operates five limited routes with ten minutes frequency and serves what may be considered the discretionary market. Sixty percent of circulator riders hold college or graduate degrees, and 18 percent bring in over $\$ 80,000$ a year. ${ }^{72}$ Interestingly, the system also appears to serve some of the transit-dependent market as well, as 44 percent make under $\$ 40,000$ a year.

In New Orleans, an urban circulator system projects to attract about 2,500 users a day, half of which currently take the bus. RTA forecasts that more people will switch from walking to this line than will switch from driving. ${ }^{73}$

The Orlando, FL LYMMO's circulator ridership for 31 months is reviewed in Figure 3-6. The figure is the first suggestion of a possible negative relationship between gas prices and transit demand. A review of service levels identifies no substantial increase in service at the time of Lymmo's highest ridership in 2009 when economic conditions and gas prices were depressed from previous levels.

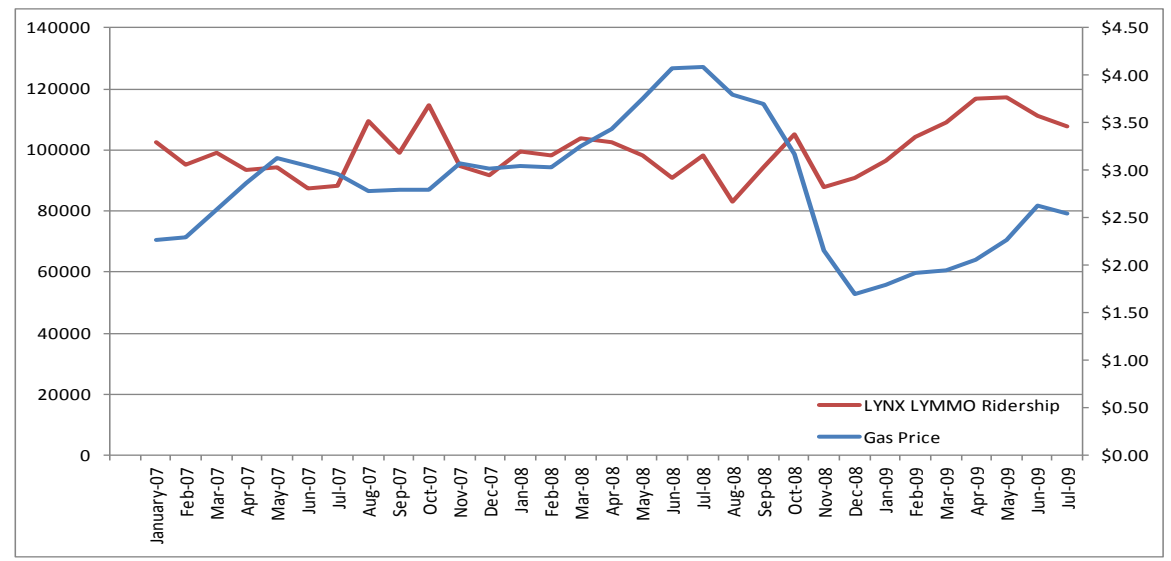

Figure 3-6: LYNX LYMMO ridership 2007-2009

As Kockelman and Bomberg theorized, demographics tell an incomplete story as to why some transit services are influenced by fuel prices. If there are discretionary riders switching to transit, there must be a trip length component or no gas price impacts are realized. If 
anything, the circulators may benefit downstream from use of other transit services that increase when gas prices rise but their use may be far more likely to be impacted by quality of service, price of parking, or walk distances.

\section{Suburban Circulators and Flexible Services}

These systems operate outside the urban core, typically within residential neighborhoods and other areas that do not meet density thresholds or accommodate full size transit coaches. The Jacksonville Transit Authority (JTA) published internal guidance in their Transit Development Plan on where these services should be used. At JTA, "connectors" are synonymous with flexible service and circulators. Table 3-1 shows JTA's Service Standards.

Table 3-1: JTA Service Standards

\begin{tabular}{|c|c|c|c|c|}
\hline \multirow{2}{*}{$\begin{array}{c}\text { Average Number of } \\
\text { Automobiles per } \\
\text { Household }\end{array}$} & \multicolumn{4}{|c|}{$\begin{array}{c}\text { Population Density } \\
\text { (Persons Per Square Mile) }\end{array}$} \\
\cline { 2 - 5 } & $\begin{array}{c}4,000 \text { and } \\
\text { above }\end{array}$ & $\begin{array}{c}2,500- \\
3,999\end{array}$ & $\begin{array}{c}1,000- \\
2,499\end{array}$ & $\begin{array}{c}\text { Under } \\
1,000\end{array}$ \\
\hline Under 1.0 & $\begin{array}{c}\text { Fixed-route } \\
\text { (1/4 Mile) }\end{array}$ & $\begin{array}{c}\text { Fixed-route } \\
\text { (1/4 Mile) }\end{array}$ & $\begin{array}{c}\text { Connectors/ } \\
\text { Loopers }\end{array}$ & $\begin{array}{c}\text { Ride } \\
\text { Request }\end{array}$ \\
\hline $1.0-1.5$ & $\begin{array}{c}\text { Fixed-route } \\
\text { (1/4 Mile) }\end{array}$ & $\begin{array}{c}\text { Fixed-route } \\
\text { (1/4 Mile) }\end{array}$ & $\begin{array}{c}\text { Connectors/ } / \\
\text { Loopers }\end{array}$ & No service \\
\hline $1.6-2.0$ & $\begin{array}{c}\text { Fixed-route } \\
\text { (1/4 Mile) }\end{array}$ & $\begin{array}{c}\text { Fixed-route } \\
\text { (1/2 Mile) }\end{array}$ & $\begin{array}{c}\text { Pide } \\
\text { Request }\end{array}$ & No service \\
\hline Over 2.0 & $\begin{array}{c}\text { Fixed-route } \\
\text { (1/2 Mile) }\end{array}$ & $\begin{array}{c}\text { Fixed-route } \\
\text { (1/2 Mile) }\end{array}$ & $\begin{array}{c}\text { Pide } \\
\text { Request }\end{array}$ & No service \\
\hline
\end{tabular}

Aside from the operating characteristics that suggest the service is not gas price sensitive, demographics also contribute to the inelastic nature of the service. A 2010 survey of the collection of more than 15 suburban circulators also known as Community Bus in Broward County revealed the following:

- More passengers under the age of 17 ride Community Buses than any other age group.

- Community buses carry a higher percentage of senior passengers than local fixed routes.

- Roughly half of community bus passengers earn less than $\$ 15,000$ per year and over 40 percent do not own a vehicle.

- School is the most common trip purpose for community bus passengers, followed by shopping and work.

- 41 percent of riders do not have a household vehicle available to make a trip

Due to higher ridership and the high use of public transportation for work and school commutes in these areas, investments to flexible public transportation service as a strategy to manage rising fuel prices may not be advised. The most frequently reported applications for flexible public transportation service in urban areas are the following:

- Suburban residential and mixed use as feeder to other transit connections 
- Office campuses

- Replacement of an unsuccessful bus route

- Urban night owl service

- Residential community constrained by geographic barriers such as lakes, mountains, etc.

- Suburban residential as circulators for senior citizens and youth

Table 3-2: TCRP 140- Flexible service markets

\begin{tabular}{|c|c|c|c|c|c|}
\hline $\begin{array}{c}\text { Trip } \\
\text { Destination/ } \\
\text { Trip Purpose }\end{array}$ & $\begin{array}{c}\text { Major } \\
\text { Shopping } \\
\text { Center }\end{array}$ & $\begin{array}{l}\text { Small } \\
\text { City } \\
\text { Center }\end{array}$ & Hospital/Clinic & $\begin{array}{l}\text { Employment } \\
\text { Center }\end{array}$ & School \\
\hline Work & \multicolumn{5}{|c|}{ Low Potential for Flexible Public Transportation } \\
\hline School & \multirow{2}{*}{\multicolumn{2}{|c|}{ Not Applicable }} & \multicolumn{2}{|c|}{ Not Applicable } & Low \\
\hline $\begin{array}{l}\text { Non-Emergency } \\
\text { Medical }\end{array}$ & & & $\begin{array}{c}\text { High } \\
\text { Potential }\end{array}$ & \multicolumn{2}{|c|}{ Not Applicable } \\
\hline Shopping/Grocery & \multirow{3}{*}{$\begin{array}{c}\text { High } \\
\text { Potential }\end{array}$} & Low & \multirow{3}{*}{\multicolumn{3}{|c|}{ Not Applicable }} \\
\hline Shopping/Other & & High & & & \\
\hline Social & & & & & \\
\hline
\end{tabular}

These riders represent the largest transit-dependent market transit agencies serve. Children under 17 and seniors are unlikely to make work trips and have fewer mobility alternatives. Suburban circulators or flexible services are likely highly inelastic bus services that are not sensitive to the price of gas.

Table 3-2 is a graphic from the TCRP 140 report which evaluated the variety of applications for flexible bus service. Flexible service has the highest potential for success for nonemergency medical trips, shopping and social trips. The lowest potential for flex service is for performing work and school trips. Flexible service is then likely to be minimally impacted by high gas prices. The trip types it performs are primarily discretionary, but performed by transit-dependent riders whose demand is inelastic with respect to gas prices. 


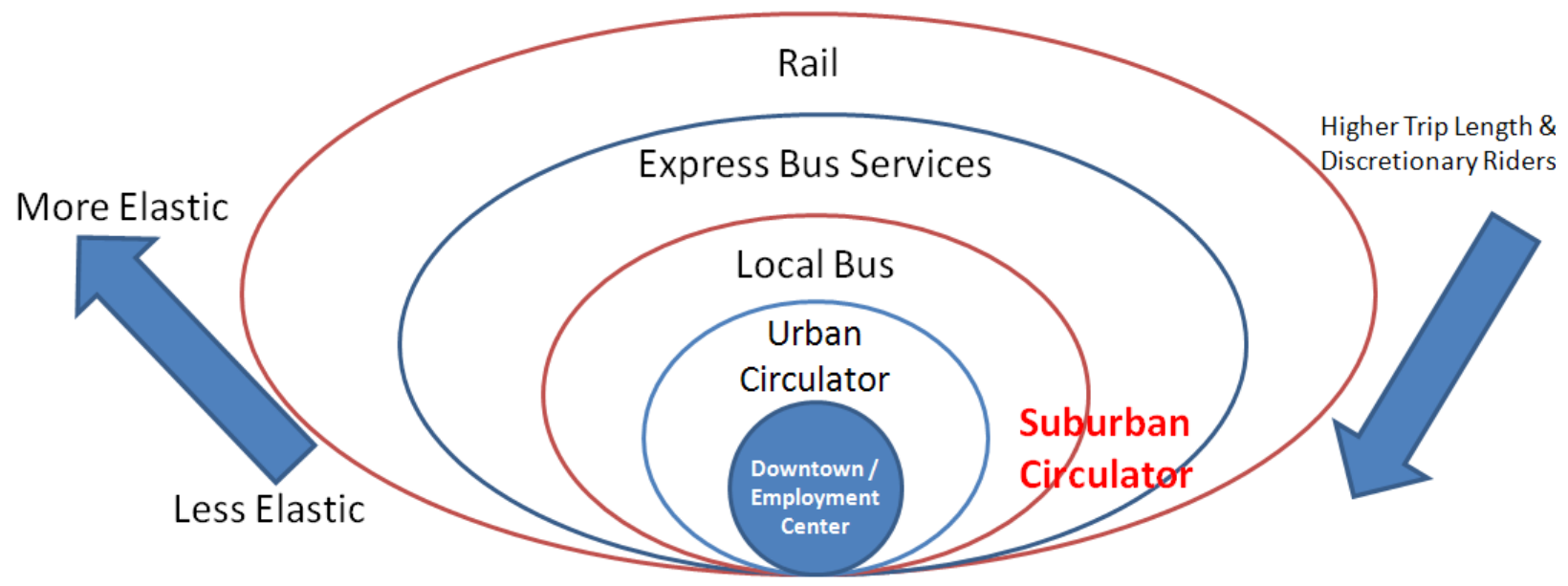

Figure 3-7: Visual representation of elasticity of transit demand with respect to gas prices by transit mode

Figure 3-7 provides a generalized, spatial perspective of transit demand and gas prices. Commute trips with longer travel distances and available auto alternatives are more elastic and transit services providing trips to dependent riders, for short, non-commute trips are likely inelastic. Recommendations for how to manage demand for these service types are suggested in Chapters 4 and 5. 


\section{Chapter 4}

\section{FLORIDA TRANSIT OPERATOR SURVEY}

\section{Florida Transit Operator Survey}

Perceptions regarding the effects of external forces on operating budgets and ridership demand as well as management strategies used by transit agencies were findings sought by this study. In order to develop some of these findings, a survey instrument was used to gather information from the providers of transit service. The purpose of administering this survey was to discover unknown conditions about the transit industry in Florida by building upon previous research and filling gaps within existing knowledge.

A 2008 APTA survey of 17 transit agencies was conducted to identify similar information, through interviews with staff presented as a series of short case studies. This report's survey was administered in order to supplement APTA's report with more current findings in 2012. These responses also fill a geographical gap in the study which did not include any Southeastern U.S. examples outside of Louisville, KY. Existing research suggests geographical differences in elasticities. These surveys were also more likely to be completed by providers in smaller service areas compared to the large and very large urban areas in the APTA report.

The survey was also important to determine if, several years after the initial $\$ 4.00$ gas price threshold, transit agencies are still seeing the effects of high fuel prices on their operations and what they have done to address these issues. It is likely that if an agency has not felt the impacts of higher fuel prices or increased ridership demand, they would be unlikely to pursue strategies to mitigate those impacts. It may also be the case that since 2008, operators have put in place mechanisms to better manage the volatility in operating costs and any associated ridership increases.

The 23-question survey was distributed through the Florida Operations Network and Florida Planning Network list services. The survey was taken by a total of 22 individuals representing an unknown number of transit operators. The survey was web administered and completed in the months of September and October of 2012. Eighteen of the 22 survey respondents ( $82 \%)$ made it through to the end of the survey, although not every question was answered.

The survey design provided for additional, more in-depth questioning where respondents identified certain conditions of interest to either reinforce or refute other research findings. The ability to find similarities between real world experiences and the body of research on gas prices and research demand provided a basis for the recommendations at the end of the study.

The survey questions covered three primary subject areas; profiles of the size and services offered by Florida's transit operators: identification of any actual (measured) or perceived 
relationship between gas prices and transit demand and any plans of action considered or implemented by agencies to address the outcomes of this relationship.

Question 1: What type of role(s) do you perform in your transit agency?

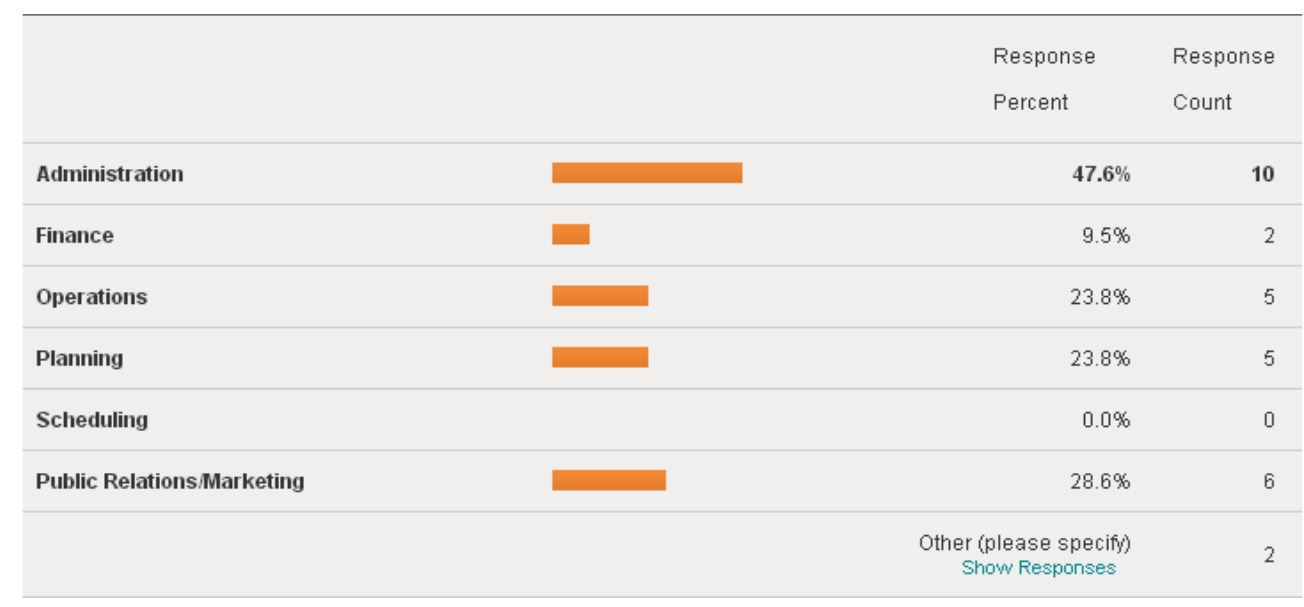

The two 'other' responses were entered as 'Mobility Management' and 'General Management'. A key takeaway from the first question is the diversity in roles in those that took the survey and the predominance of administrative and management titles in the survey population. These are assumed to be position types that would have a more comprehensive understanding of agency practices.

\section{Question 2: How many years have you worked at your current transit agency?}

\begin{tabular}{|c|c|c|c|}
\hline & & Response & Response \\
\hline & & Percent & Count \\
\hline Less than 3 years & 口 & $30.0 \%$ & 6 \\
\hline 3 to 6 years & $\square$ & $20.0 \%$ & 4 \\
\hline 6 to 10 years & $\square$ & $10.0 \%$ & 2 \\
\hline More than 10 years & 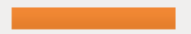 & $\mathbf{4 0 . 0} \%$ & 8 \\
\hline
\end{tabular}

The respondents split at $50 \%$ with fewer than six years of experience at their current transit agency employer and $50 \%$ with 6 or more years at their current agency. The relevance of this question lies in survey respondents' ability to recount $\$ 4.00$ gas in 2008 and the continuity of employment at their current agency. Survey takers that had a longer length of employment were more likely to be able to appreciate the difference over time of the effects of rising gas prices and know what actions had been taken to address them. 
Question 3: What size is your transit agency?

\begin{tabular}{|c|c|c|c|}
\hline & & Response & Response \\
\hline & & Percent & \\
\hline Fewer than 25 vehicles & 口 & $5.3 \%$ & 1 \\
\hline $26-50$ vehicles & $\square$ & $21.1 \%$ & 4 \\
\hline $51-100$ vehicles & 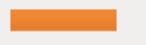 & $26.3 \%$ & 5 \\
\hline $101-200$ vehicles & 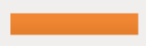 & $31.6 \%$ & 6 \\
\hline 201-400 vehicles & $\square$ & $10.5 \%$ & 2 \\
\hline Larger than 400 vehicles & 口 & $5.3 \%$ & 1 \\
\hline
\end{tabular}

Consistent with the profile of many of Florida's transit agencies, the majority of survey respondents were employed by transit agencies with 200 fleet vehicles or fewer. These midto small-sized systems were underrepresented in the APTA study, which was made up primarily of systems serving major urban areas. The research indicates these small to midsize service providers and the metro areas they serve, had different elasticities than the larger systems. Case studies in the Pacific Northwest and Plains states found their local bus systems with significant positive effects of rising gas prices on influencing ridership in small urban and rural areas.

\section{Question 4: Does your transit agency offer any of the following services? [Check all that apply].}

\begin{tabular}{|lrr|}
\hline & $\begin{array}{c}\text { Response } \\
\text { Percent }\end{array}$ & $\begin{array}{c}\text { Response } \\
\text { Count }\end{array}$ \\
\hline Fixed Route & $\mathbf{8 5 . 0 \%}$ & $\mathbf{1 7}$ \\
\hline Paratransit or Demand Response & $\mathbf{8 5 . 0 \%}$ & $\mathbf{1 7}$ \\
\hline Bus Rapid Transit & $15.0 \%$ & 3 \\
\hline Fixed Guideway (Rail) & $5.0 \%$ & 1 \\
\hline Express or Limited Stop Service & $55.0 \%$ & 11 \\
\hline Flexible or Route Deviated Service & $50.0 \%$ & 10 \\
\hline Local Feeder/Community Bus & $5.0 \%$ & 1 \\
\hline Circulator & Other (please specify) & 1 \\
\hline & Show Responses & 5 \\
\hline
\end{tabular}

The one 'other' response was for 'Vanpool'. Most of the survey respondents worked for systems that offer bus services with a limited number of other modes. The literature review and subsequent analysis of two transit agencies reflect the predominance of bus service in the state of Florida, with rail lines operating only in larger urban metros. 
Question 5: Gas prices notably reached $\$ 4.00$ per gallon in many places in July 2008 and almost did again earlier in 2012. Has your agency ever experienced an actual or perceived increase in ridership or demand that was thought to be caused by high gas prices?

\begin{tabular}{|c|c|c|c|}
\hline & & Response & Response \\
\hline & & Percent & Count \\
\hline Yes & 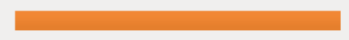 & $89.5 \%$ & 17 \\
\hline No & 口 & $5.3 \%$ & 1 \\
\hline I don't know & 口 & $5.3 \%$ & 1 \\
\hline
\end{tabular}

Nearly all of the survey respondents said they had experienced gas price influenced ridership at their agency. The true causes of ridership growth can be difficult to determine at the agency level. It is notable that 17 of the 19 respondents reported that they had an actual or perceived increase in ridership.

Question 6: Which of the following services experienced an increase in ridership demand due to high gas prices at your transit agency? [Click all that apply].

\begin{tabular}{lrr|}
\hline & Response & $\begin{array}{c}\text { Response } \\
\text { Count }\end{array}$ \\
\hline Fixed Route & $\mathbf{P e r c e n t}$ & $\mathbf{1 4}$ \\
\hline Paratransit or Demand Response & $29.4 \%$ & 5 \\
\hline Bus Rapid Transit & $5.9 \%$ & 1 \\
\hline Commuter Routes/Services & $11.8 \%$ & 2 \\
\hline Fixed Guideway (Rail) & $5.9 \%$ & 1 \\
\hline Express or Limited Stop Service & $41.2 \%$ & 7 \\
\hline Flexible or Route Deviated Service & $11.8 \%$ & 2 \\
\hline Local Feeder/Community Bus & $5.9 \%$ & 1 \\
\hline Circulator & $17.6 \%$ & 3 \\
\hline I don't know & $0.0 \%$ & 0 \\
\hline & Other (please specify) & 1 \\
\hline
\end{tabular}


If a respondent answered 'Yes' to the previous question they were allowed to answer Question 6. These responses illustrate any perceived modal demand differences. Notably, 'Paratransit or Demand Response' were operated by the same number of agencies as 'Fixed Route' in Question 5, yet $82 \%$ of respondents realized an ridership increase in fixed route but only $29 \%$ did in paratransit/demand response.

Question 7: Should gas prices exceed $\$ 4.00$ per gallon again, which of the following services would you recommend to be increased? [Click all that apply].

\begin{tabular}{|lcc|}
\hline & Response & Response \\
& Percent & Count \\
\hline Fixed Route & $75.0 \%$ & 12 \\
\hline Paratransit or Demand Response & $25.0 \%$ & 4 \\
\hline Bus Rapid Transit & $12.5 \%$ & 2 \\
\hline Commuter Routes/Services & $18.8 \%$ & 3 \\
\hline Fixed Guideway (Rail) & $6.3 \%$ & 1 \\
\hline Express or Limited Stop Service & $31.3 \%$ & 5 \\
\hline Flexible or Route Deviated Service & $25.0 \%$ & 4 \\
\hline Local Feeder/Community Bus & $12.5 \%$ & 2 \\
\hline Circulator & $6.3 \%$ & 1 \\
\hline I don't know & $6.3 \%$ & 1 \\
\hline & Other (please specify) & 0 \\
\hline
\end{tabular}

This survey question is intended to gauge the perception of which of the modes would be effective in meeting any increased service demand produced by rising gas prices. Most modes that were reported with ridership increases in Question 6, decreased in the number of responses when it came to recommendations for adding service. Exceptions included 'Bus Rapid Transit' and 'Commuter Routes/Services', which increased with responses compared to Question 6. However, the perception that fixed route bus would be most impacted is still very high. 


\section{Question 8: Which of the following price thresholds for gasoline appear to trigger increases in ridership demand at your agency? [Please click all that apply].}

\begin{tabular}{l|rr|}
\hline & $\begin{array}{c}\text { Response } \\
\text { Percent }\end{array}$ & $\begin{array}{c}\text { Response } \\
\text { Count }\end{array}$ \\
\hline$\$ 3.00$ per gallon & $6.3 \%$ & 1 \\
\hline$\$ 3.50$ per gallon & $37.5 \%$ & 6 \\
\hline$\$ 4.00$ per gallon & $68.8 \%$ & 11 \\
\hline $\begin{array}{l}\text { Gas price thresholds do not trigger ridership at } \\
\text { my agency }\end{array}$ & $0.0 \%$ & 0 \\
\hline I dont know & $6.3 \%$ & 1 \\
\hline & Other (please specify) & 0 \\
\hline
\end{tabular}

Survey respondents identified consumer gas price triggers at both $\$ 3.50$ and $\$ 4.00$ per gallon. The majority of survey participants that answered this question found $\$ 4.00$ to be the gas price that was related to higher transit service demand.

\section{Question 9: Please check the scenario below that most accurately reflects your ridership or demand when gas prices increase.}

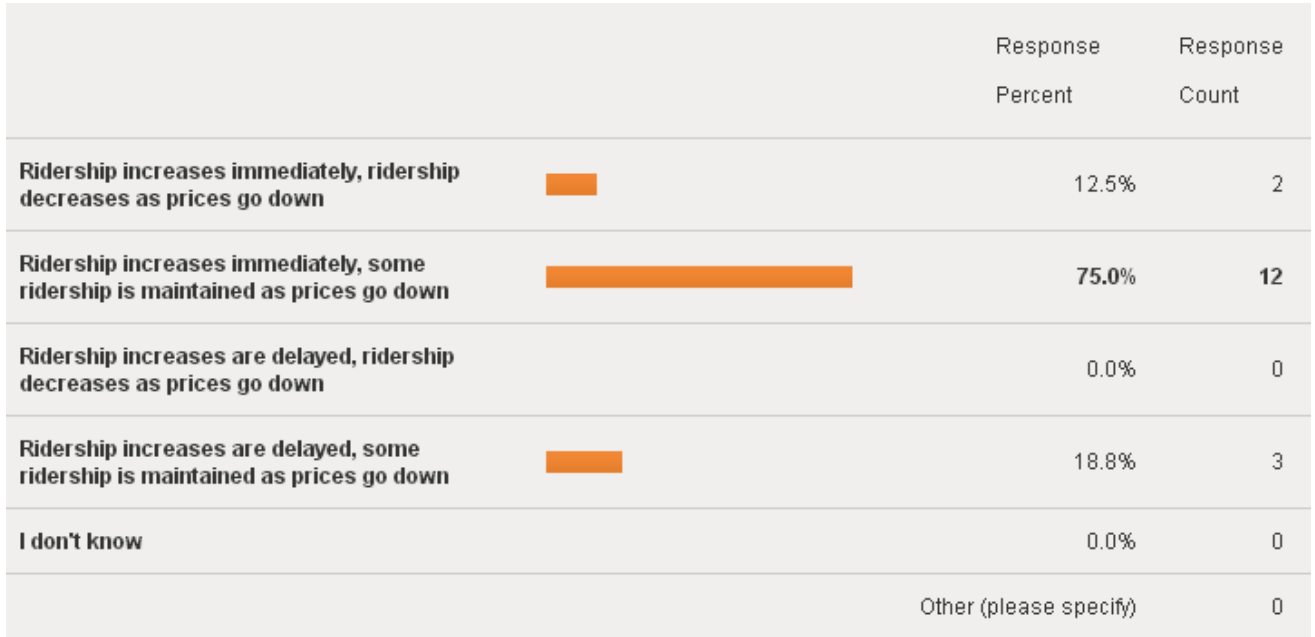

Approximately, $75 \%$ of the respondents to this question found that when gas prices increased, ridership increased immediately and some ridership was maintained as prices go down. This finding supports the asymmetrical nature of ridership demand related to gas prices as described in the research. Of interest here is that the survey respondents were more aligned with the findings of Mattson and others that found only a 1 or 2 month lag in ridership rather than the research that found lags of 3 months or more. 
Question 10: Did your local media attribute any increases in ridership to higher gas prices?

\begin{tabular}{l|rr} 
& Response & \multicolumn{1}{c}{$\begin{array}{c}\text { Response } \\
\text { Count }\end{array}$} \\
\hline Yes & $\mathbf{6 6 . 7 \%}$ & $\mathbf{1 2}$ \\
\hline No & $11.1 \%$ & 2 \\
\hline I don't know & $22.2 \%$ & 4 \\
\hline
\end{tabular}

Consistent with findings in the Literature Review, media coverage of the impacts of high gas prices generally suggested a positive relationship with transit demand. A small amount of media coverage may convey that the relationship is unclear or it may not get reported at all. This was only relevant where any surge in demand was found. Not all agencies experienced significant increases.

Question 11: Has your transit agency raised fares in recent years to compensate for either a decline in operating revenue or increase in diesel prices for bus operations?

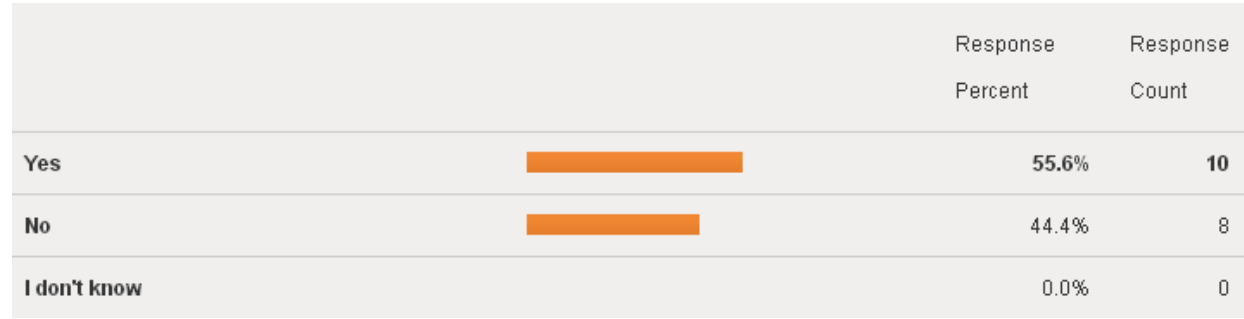

Just over half of the survey respondents reported a fare increase in recent years. This has been one strategy identified in research to either fund more service or what is more likely, to compensate for additional costs or reduced revenues. The negative relationship between fare increases and ridership is typically well understood by transit operators, therefore it is likely that any fare price increases were sought to cover funding gaps.

\section{Question 12: Has your transit agency cut service in recent years to compensate for declining operating revenue?}

\begin{tabular}{llll}
\hline & Response & \multicolumn{2}{c}{ Response } \\
& Percent & Count \\
\hline Yes & $\mathbf{6 1 . 1 \%}$ & $\mathbf{1 1}$ \\
\hline No & $38.9 \%$ & 7 \\
\hline I don't know & $0.0 \%$ & 0 \\
\hline
\end{tabular}

More than $60 \%$ of question 12 respondents had experienced service cuts at their transit agencies in recent years. Service cuts implemented when gas price peaked have the 
potential to undercut the ability of agencies to develop new ridership, unless only underperforming service is cut. Service cuts necessary when revenues decline can be made with varying levels of impact as to preserve as much ridership and customer satisfaction as possible. A transit agency with high quality data on where and when ridership uses transit can better navigate this process.

Question 13: Does your transit agency or county government (if applicable) purchase fuel via multi-year contracts? Fuel price contracts lock in a fixed price for gasoline and typically are used for budget predictability year over year and to hedge against future rises in gas prices.

\begin{tabular}{llcc}
\hline & & Response & Response \\
& Percent & Count \\
\hline Yes & $38.9 \%$ & 7 \\
\hline No & $16.7 \%$ & 3 \\
\hline I don't know & $\mathbf{4 4 . 4 \%}$ & $\mathbf{8}$ \\
\hline
\end{tabular}

Independent transit authorities and both City and County government-operated transit agencies can all utilize multi-year fuel contracts to lock in gas prices for vehicle fueling. Administrative, finance, management, or centralized purchasing staff is most likely to be aware of this practice at their agency. Therefore, the high number of 'I don't know' responses suggested the plurality of respondents that are unaware may be planning, operations, or public relations staff.

\section{Question 14: What are the mechanisms in your fuel contract(s) that define how fuel costs} are to be paid? [Click all that apply].

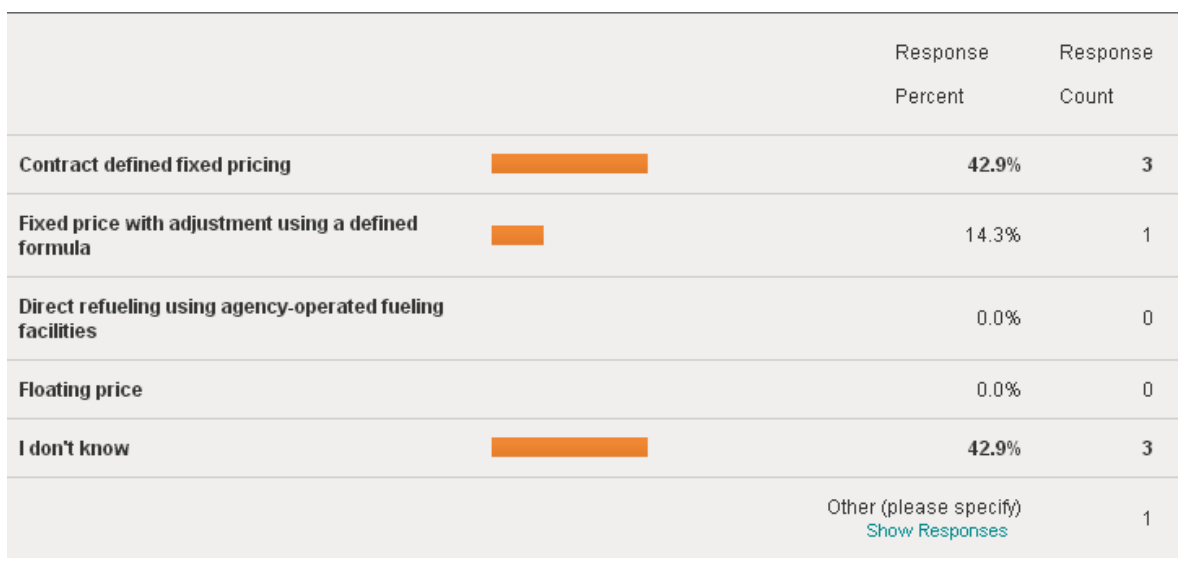

The one 'Other' response was that the County fleet management department manages the fuel contracts. This question was only presented if Question 13 indicated a fuel price 
contract was used at an agency. The predominant response was for a defined fixed price; a single respondent indicated that fixed price allowed for an adjustment with a contractually defined formula. Typically, contracts that include an adjustment formula diffuse some of the risk present when executing a multi-year fuel purchasing agreement between the transit operator and retailer.

\section{Question 15: Does your transit agency contract any portion of its service to a third party?}

\begin{tabular}{|l|cr|}
\hline Yes & $77.8 \%$ & $\mathbf{1 4}$ \\
\hline No & $22.2 \%$ & 4 \\
\hline I don't know & $0.0 \%$ & 0 \\
\hline
\end{tabular}

Greater than 3 out of 4 respondents to this question stated their transit agency contracted out at least some portion of their service. All but one of the mode responses from Question 4 were bus and van operations. The large majority of this contracting was done for paratransit service as less than $3 \%$ of all fixed route service is contracted out.

Question 16: When using third parties to perform transportation services on behalf of a transit agency, there are often different methods for sharing fuel costs over the life of the contract. Are you aware of any of the following methods for fuel price costs sharing?

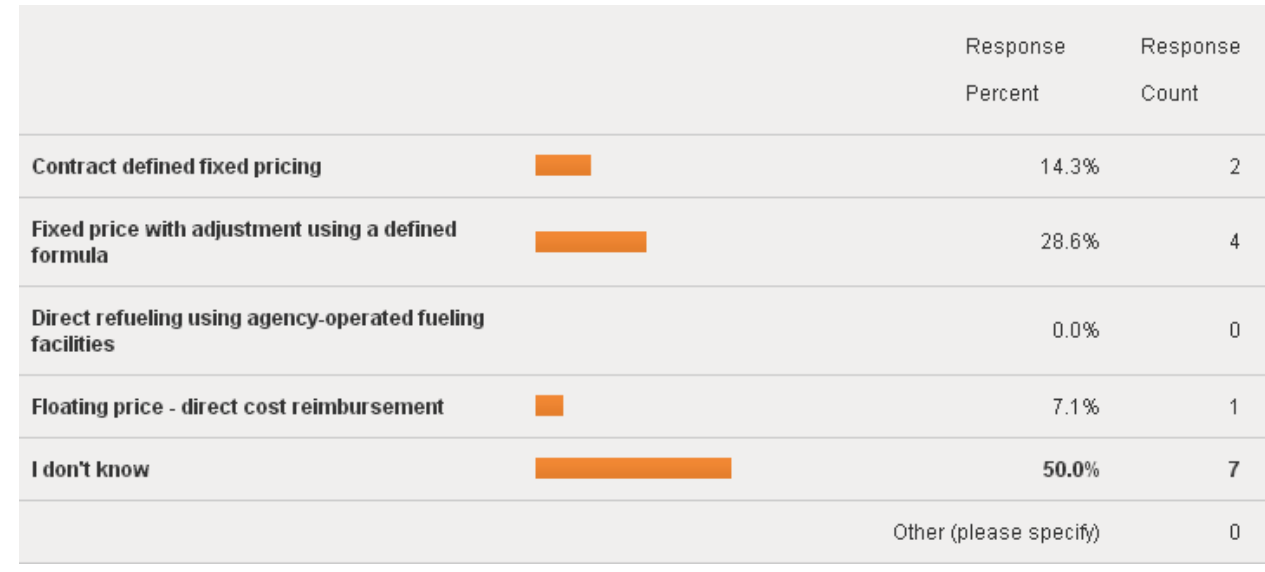

Half of the respondents were not aware of the assignment of responsibility of fuel costs in their contracts. The majority of those that did know how their contracts were structured stated that fixed price fuel costs with adjustment using a defined formula was the mechanism used. This practice, along with direct cost reimbursement, may be preferred in contracted services in many cases because it does not jeopardize the financial health of the contractor should a dramatic spike in fuel prices occur. 


\section{Question 17: Does your transit agency operate alternative fuel vehicles?}

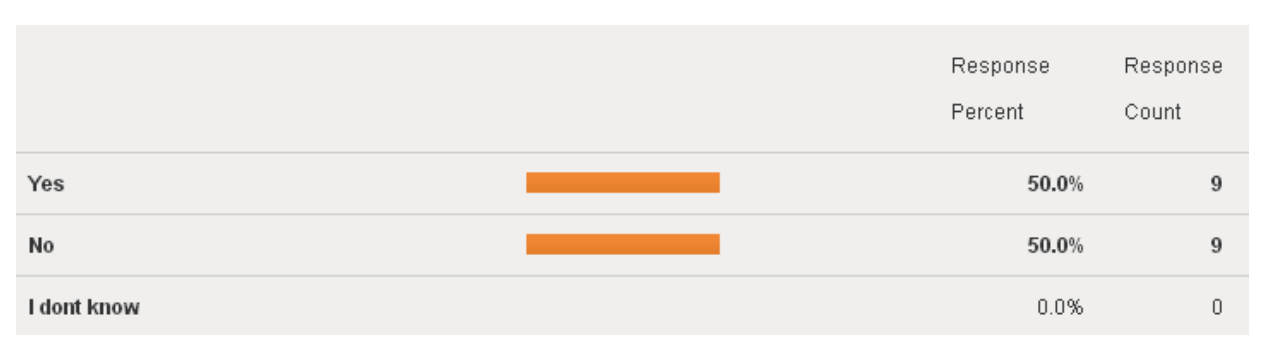

Fifty percent of the individuals who completed the survey reported their agency operated at least some alternative fuel vehicles.

\section{Question 18: What percentage of your fleet operates on alternative fuels?}

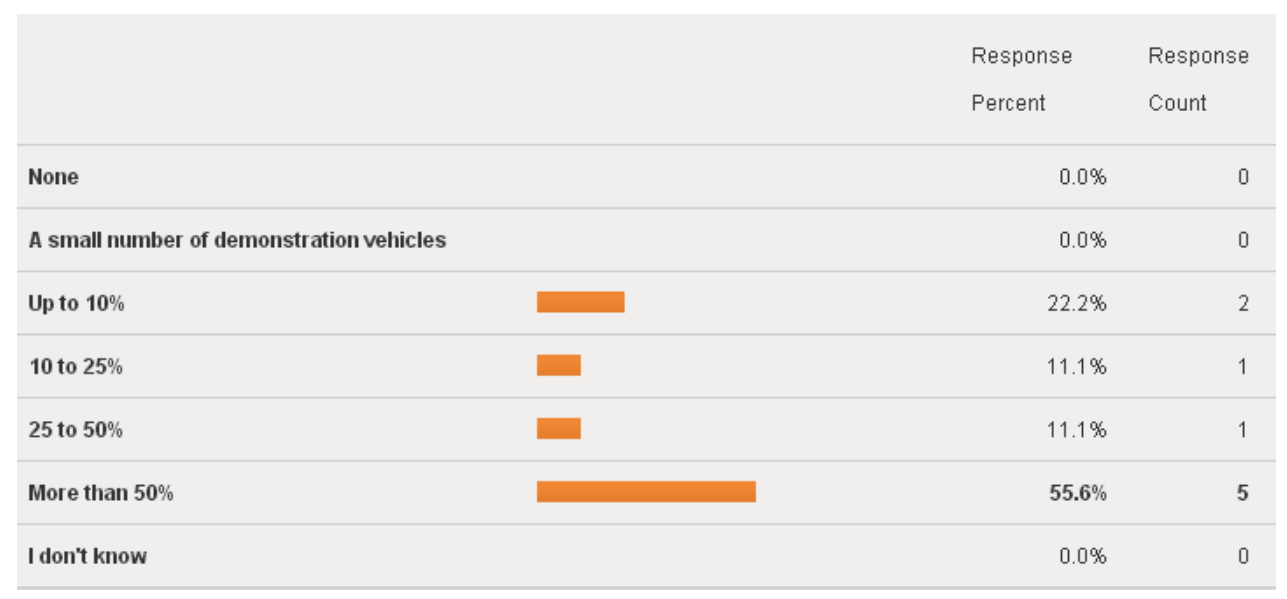

If a survey taker responded 'Yes' to Question 17, then Question 18 asked what portion of their vehicle fleet used alternative fuels. The results are somewhat surprising that the majority of those agencies with alternative fuel vehicles have fleet made up of more than $50 \%$ of these types. It is possible the survey takers are including hybrid buses, which are considered alternative propulsion vehicles, but are still reliant on traditional fuel sources. Alternative fuel vehicles typically require more capital investment to purchase than a standard diesel engine bus and can need infrastructure such as specialized fuel stations to refill compressed or liquefied natural gas. 

Question 19: Please rank from most important (1) to least important (7) the
reasons why your agency operates alternative fuel vehicles.

\begin{tabular}{|c|c|c|c|c|c|c|c|c|c|}
\hline & 1 & 2 & 3 & 4 & 5 & 6 & 7 & $\begin{array}{l}\text { Rating } \\
\text { Average }\end{array}$ & $\begin{array}{l}\text { Response } \\
\text { Count }\end{array}$ \\
\hline $\begin{array}{l}\text { To decrease the amount of } \\
\text { pollutants emitted by our vehicles. }\end{array}$ & $\begin{array}{r}66.7 \% \\
(6)\end{array}$ & $\begin{array}{r}0.0 \% \\
(0)\end{array}$ & $\begin{array}{r}0.0 \% \\
(0)\end{array}$ & $\begin{array}{r}11.1 \% \\
(1)\end{array}$ & $\begin{array}{r}0.0 \% \\
(0)\end{array}$ & $\begin{array}{r}22.2 \% \\
(2)\end{array}$ & $\begin{array}{r}0.0 \% \\
(0)\end{array}$ & 2.44 & 9 \\
\hline $\begin{array}{l}\text { To save money on fuel costs to } \\
\text { operate the vehicles. }\end{array}$ & $\begin{array}{r}22.2 \% \\
(2)\end{array}$ & $\begin{array}{r}55.6 \% \\
(5)\end{array}$ & $\begin{array}{r}0.0 \% \\
(0)\end{array}$ & $\begin{array}{r}0.0 \% \\
(0)\end{array}$ & $\begin{array}{r}22.2 \% \\
(2)\end{array}$ & $\begin{array}{r}0.0 \% \\
(0)\end{array}$ & $\begin{array}{r}0.0 \% \\
(0)\end{array}$ & 2.44 & 9 \\
\hline $\begin{array}{l}\text { To be on the leading edge of } \\
\text { technological innovation. }\end{array}$ & $\begin{array}{r}11.1 \% \\
(1)\end{array}$ & $\begin{array}{r}11.1 \% \\
(1)\end{array}$ & $\begin{array}{r}44.4 \% \\
(4)\end{array}$ & $\begin{array}{r}22.2 \% \\
(2)\end{array}$ & $\begin{array}{r}0.0 \% \\
(0)\end{array}$ & $\begin{array}{r}0.0 \% \\
(0)\end{array}$ & $\begin{array}{r}11.1 \% \\
(1)\end{array}$ & 3.33 & 9 \\
\hline $\begin{array}{l}\text { Because grant funding to } \\
\text { purchase these specialized } \\
\text { vehicles was available under } \\
\text { TIGGER or another program. }\end{array}$ & $\begin{array}{r}0.0 \% \\
(0)\end{array}$ & $\begin{array}{r}22.2 \% \\
(2)\end{array}$ & $\begin{array}{r}11.1 \% \\
(1)\end{array}$ & $\begin{array}{r}22.2 \% \\
(2)\end{array}$ & $\begin{array}{r}11.1 \% \\
(1)\end{array}$ & $\begin{array}{r}11.1 \% \\
(1)\end{array}$ & $\begin{array}{r}22.2 \% \\
(2)\end{array}$ & 4.44 & 9 \\
\hline $\begin{array}{l}\text { To save on vehicle maintenance } \\
\text { costs. }\end{array}$ & $\begin{array}{r}0.0 \% \\
(0)\end{array}$ & $\begin{array}{r}11.1 \% \\
(1)\end{array}$ & $\begin{array}{r}22.2 \% \\
(2)\end{array}$ & $\begin{array}{r}11.1 \% \\
(1)\end{array}$ & $\begin{array}{r}33.3 \% \\
(3)\end{array}$ & $\begin{array}{r}0.0 \% \\
(0)\end{array}$ & $\begin{array}{r}22.2 \% \\
(2)\end{array}$ & 4.56 & 9 \\
\hline $\begin{array}{l}\text { To comply with legislation or } \\
\text { other local or regional initiatives. }\end{array}$ & $\begin{array}{r}0.0 \% \\
(0)\end{array}$ & $\begin{array}{r}0.0 \% \\
(0)\end{array}$ & $\begin{array}{r}11.1 \% \\
(1)\end{array}$ & $\begin{array}{r}11.1 \% \\
(1)\end{array}$ & $\begin{array}{r}11.1 \% \\
(1)\end{array}$ & $\begin{array}{r}44.4 \% \\
(4)\end{array}$ & $\begin{array}{r}22.2 \% \\
(2)\end{array}$ & 5.56 & 9 \\
\hline $\begin{array}{l}\text { To project a certain image of the } \\
\text { transit service to the customer. }\end{array}$ & $\begin{array}{r}0.0 \% \\
(0)\end{array}$ & $\begin{array}{r}0.0 \% \\
(0)\end{array}$ & $\begin{array}{r}11.1 \% \\
(1)\end{array}$ & $\begin{array}{r}22.2 \% \\
(2)\end{array}$ & $\begin{array}{r}22.2 \% \\
(2)\end{array}$ & $\begin{array}{r}22.2 \% \\
(2)\end{array}$ & $\begin{array}{r}22.2 \% \\
(2)\end{array}$ & 5.22 & 9 \\
\hline
\end{tabular}

The nine survey respondents that stated their transit agency operated alternative fuel vehicles were asked to rank the reasons they operated them from most important to least important. The resulting answers identified environmental impact mitigation as the primary reason for switching to alternative fuel vehicles followed closely by an expected reduction in fuel costs.

Question 20: Does your transit agency maintain a contingency fleet? The Federal Transit Administration defines a contingency fleet as: Buses may be stockpiled in an inactive contingency fleet in preparation for emergencies. No bus may be stockpiled before it has reached the end of its service life. Buses held in a contingency fleet must be properly stored, maintained and documented in a contingency plan. These vehicles do not count in the calculation of spare ratio.

\begin{tabular}{l|cc}
\hline & Response & \multicolumn{2}{c}{ Response } \\
& Percent & Count \\
\hline Yes & $38.9 \%$ & 7 \\
\hline No & $38.9 \%$ & 7 \\
\hline I Don't Know & $22.2 \%$ & 4 \\
\hline
\end{tabular}

Of the 14 survey respondents that were aware if their agency maintained a contingency fleet of transit vehicles, half reported that they did in fact keep vehicles that were not operating in daily service. These contingency fleets can be used to ramp up service in high demand areas on short notice. 
Question 21: Does your transit agency use promotions such as Dump the Pump or other marketing initiatives that promote transit use directly based on the high price of gasoline?

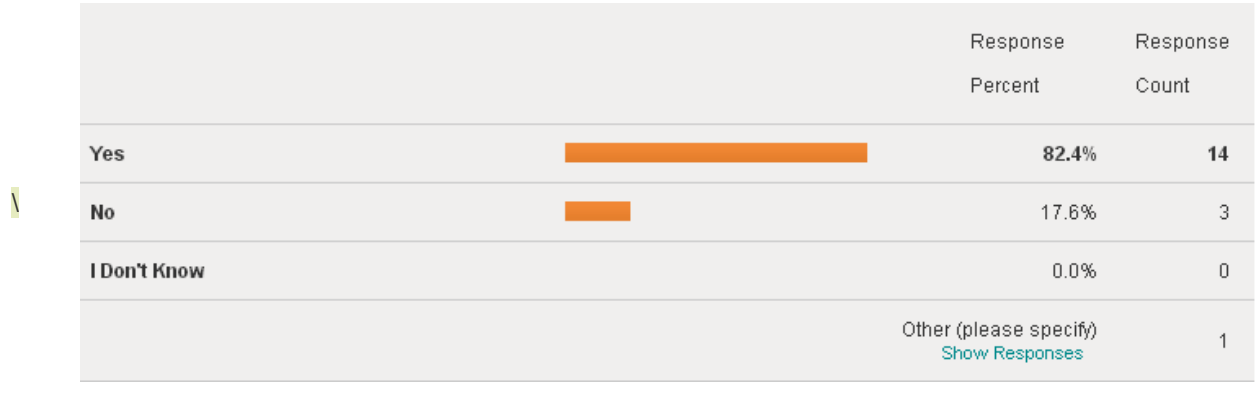

Transit agencies often reinforce the personal finance advantages that are possible when one chooses to ride public transportation instead of a single occupancy vehicle. Eighty-two percent of survey respondents to this question stated their agency has used these types of messages in marketing and outreach campaigns.

Question 22: In summary, does your transit agency use any of the following SHORT-TERM strategies to manage demand from gas prices to maximize ridership and preserve customer satisfaction? [Click all that apply].

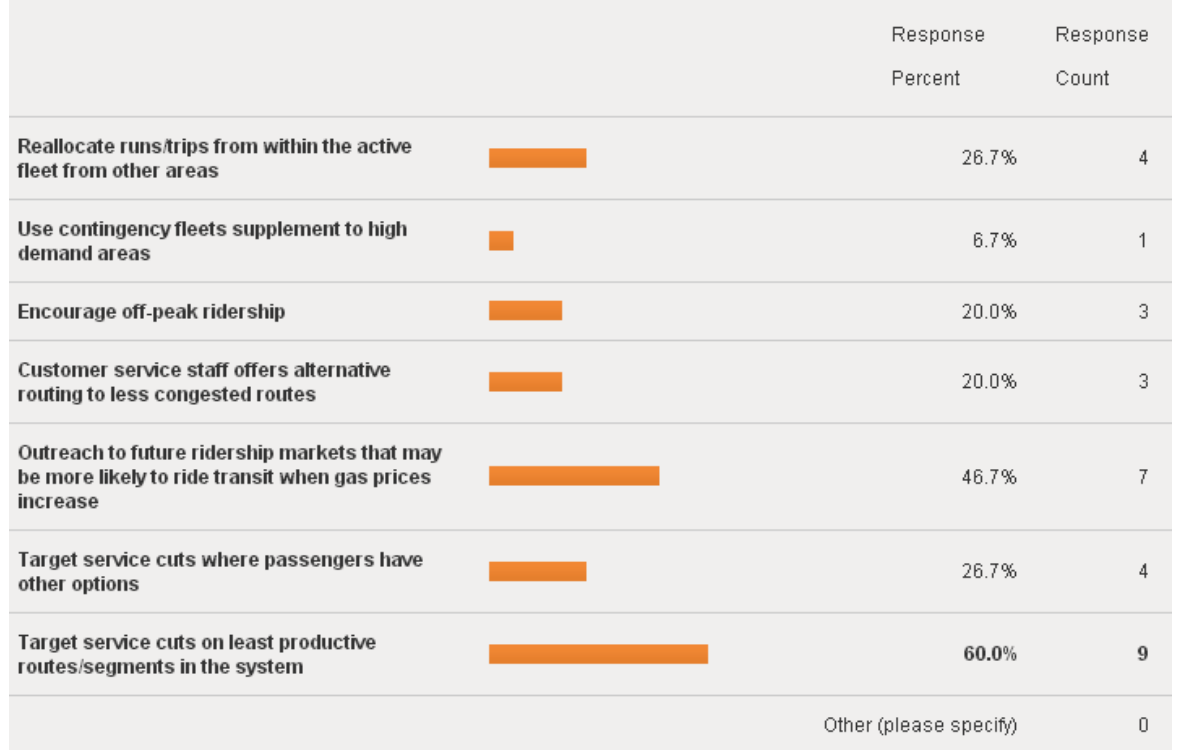


Question 23: In summary, does your transit agency use any of the following LONGTERM strategies to manage demand from gas prices to maximize ridership and preserve customer satisfaction? [Click all that apply].

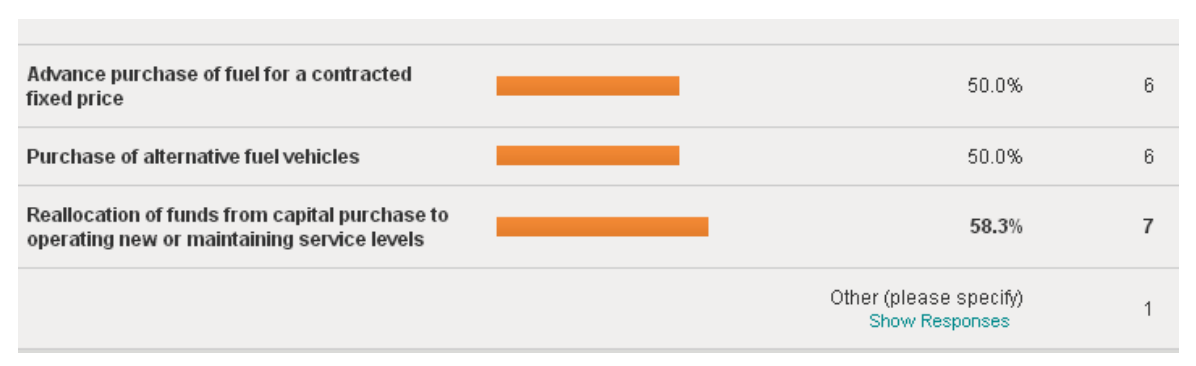

Questions 22 \& 23 sought to gain insight on the mechanisms Florida's transit providers have used to address any increase in transit demand or compensate for higher costs/lower revenues for both short- and long-term timeframes. Notably, there were a relatively low number of agencies that used contingency fleets to add service on demand. This may be in part due to a lack of funding or employed operators available to run the vehicles in service. In addition, 60 percent of respondents stated their agency had targeted cuts on the least productive routes and route segments in their system. It is unlikely contingency fleets are needed when operating revenues drop.

The one response for 'Other' stated that 'Possibly option number 3 '. Longer term strategies are those that cannot typically be immediately employed and the benefits from them may occur over the course of many months or even years. For example, the lead time on purchase of alternative propulsion or alternative fuel vehicles (Electric, Hybrid electric, Natural Gas, Fuel Cell) can be a year wait or more, depending on the number of orders the manufacturer has to fulfill. Reprogramming capital funding programs can take many months as projects approved for construction or capital purchase may need to be delayed in order to reallocate resources to maintain or enhance operations.

\section{Summary of Survey Findings}

The predominant characteristics of survey respondents were:

- Administrative staff to mid and small sized transit agencies in Florida

- Likely to be either long time employed (greater than 10 years) or relatively new to the organization (less than 3 years)

- Representing systems that provide bus services; offering fixed route, paratransit/demand response, express bus, and route deviated lines

The predominant perceptions about gas prices and transit demand were:

- $\$ 4.00$ per gallon consumer gas prices do positively influence ridership at transit agencies, while half as many respondents believe $\$ 3.50$ gas also triggers ridership increases

- Service types most affected when prices increase are fixed route (local) and express or limited stop service 
- When gas prices increase, fixed route and express or limited stop are service types recommended for improvements

- Consistent with previous research findings regarding brief lags and asymmetry, most respondents stated the ridership increases immediately after gas price spikes and that some ridership is maintained as prices go back down

- Local media attributes at least some increases in ridership at agencies to gas prices

The predominant perceptions about strategies to manage the effects of high gas prices (within a larger context of balancing operating budgets) were:

- Many agencies purchase fuel for owned and operated vehicles via multi-year agreements with contract defined fixed pricing

- Most agencies are contracting out at least some portion of their transit service with a provision to allow the contractor payments to be adjusted for increasing fuel costs based on a defined formula

- Half of reporting agencies operate alternative fuel vehicles, which in many cases, make up more than half of their fleet

- The top 2 reasons for operating alternative fuel vehicles are to decrease the amount of pollutants emitted by vehicles and to save money on fuel costs

- Marketing and outreach activities are undertaken to persuade people to use public transportation as a way to save money

- Popular short-term strategies for managing demand and budget impacts from fuel prices include targeting service cuts to the least productive routes/segments in the system and outreach to future ridership markets

- Popular long-term strategies for managing demand and budget impacts from fuel prices include reallocating funds from capital purchases to operations, using fuel contracts and operating alternative fuel vehicles 


\section{Chapter 5}

\section{STRATEgIES FOR TRANSIT OPERATORS}

The literature review and subsequent analyses explored the relationship between gas prices and ridership and established the basis for an approach to manage the small, but statistically significant increase in demand of certain transit modes when gas prices increase. The survey uncovered the perspectives of transit providers in the state of Florida and what, if any actions they have employed to preserve customer satisfaction and increase ridership when fuel prices increase.

An assembly of transit demand management strategies is provided, categorized into both those that can be used immediately to adapt to rapid price rises, as well as long-term strategies that can lessen the impact gas prices have on transit provision over time. The candidate market is the discretionary rider, on commute trips, during peak hour service with travel times that can be improved or at minimum be made comparable to private auto.

Because gas prices are volatile and there is often a lag in development of ridership as a result of price spikes, longer term solutions gain in importance as short-term effects and strategies are less constant. Long-term actions are those that create a foundation that best insulates the transit agency from variable fuel costs and offer the best mode alternative to those seeking to depart from private auto travel.

Going forward, it is important to monitor the development of certain trends that could alter these relationships. There is some evidence of a less auto inclined youth generation. ${ }^{74}$ The high cost of transportation as a percentage of total income may already be impacting the decision to own and operate a private auto. Also, the decentralized nature of employment and practice of telecommuting could mean less demand for work trips.

Finally, there are questions as to whether the spread of poverty beyond urban centers is temporary or part of a longer term trend. If this is sustained, gas prices could disproportionally impact those in suburban and exurban areas with little transit service and low income versus the urban low income population where transit levels are likely to be higher.

\section{Short-Term Strategies}

There are a number of activities that could be employed to quickly respond to vehicle crowding or full vehicles based on information from the literature review, APTA study and the survey described in Chapter 4 . These actions are described below: 


\section{Service Optimization}

\section{Contingency Fleets}

The survey of Florida's transit providers indicated approximately half maintain a contingency fleet of vehicles. These reserve vehicles are typically those that have reached their useful life as defined by FTA and are kept to be used in emergencies or during special events. They continue to be maintained as to keep them prepared to supplement the active fleet. Many agencies may dispose or send their vehicles to auction, particularly when there are no apparent needs for them or they do not have the physical space required to stow them. These vehicles do however, provide short-term capacity to increase service under certain conditions.

Lead times to procure new vehicles may be 12 months or more, rendering the purchase of new vehicles to increase service in times of demand as a long-term option. Contingency vehicles are best suited to address short-term fluctuations in price and demand because they can be quickly activated and put into service. More challenging may be meeting the needs for additional personnel to operate new service. Short-term increases in vehicle operator hours and availability could be addressed through extra boards or be negotiated into labor agreements if demand increases as part of extraordinary circumstances that require daily plug runs or trippers.

\section{Reallocation and Reduction of Service}

Where contingency fleets may be of use when demand increases and the resources exist to ramp up service to meet the demand, reallocation of resources and service reduction may be needed where resources are constant or in decline. This becomes particularly difficult to manage when transit demand rises but resources become scarcer. As gas price increases are more likely to affect the discretionary rider, some methods of reallocation or cuts can be the best option in times of high gas prices.

\section{Coverage or Frequency}

The Florida transit operator survey found at better than 2 to 1 , transit providers target service cuts from the least productive routes and route segments in the system rather than targeting service cuts where riders have other travel options. These conditions could both exist in some scenarios. For example, express routes that serve areas with high auto availability where use is low could meet both criteria. However, if reduction is sought for an area with riders that are highly sensitive to fuel price, transit agencies might consider cutting frequency before coverage (eliminating the route) as transit access has been found to be a key determinant of whether one uses transit. Access to transit during morning and afternoon peaks should be preserved even if off-peak service is diminished, as the research shows lag between the time gas prices go up and ridership starts to build when gas prices are high. 


\section{Customer Service Suggested Alternatives}

Regions within the service area with sufficient levels of service may have more than one transit routing alternative to complete a trip. The 2008 APTA study found some transit agencies running full buses were passing up riders that in turn, may become discouraged with access to transit. Web based trip planners and customer service agents should be able to offer more than one trip option when available. In particular, customer service staff should be aware of buses operating with crush loads and suggest alternative routes to passengers to maximize their potential to use the service.

\section{Marketing and Outreach}

One way to encourage ridership during times of high gas prices would be to conduct outreach or marketing campaigns within parts of the service area where there is commuteroriented service, long average commute times, high auto availability, and adequate transit access. The U.S. Census and American Community Survey (ACS) publish geographically based data that can be mined for a more in-depth understanding of where these areas are within an agency's service zone. Marketing and outreach could also include mailings with service maps and free ride passes to encourage individuals to try transit.

\section{Encourage Off-Peak Ridership, Peak-Hour Fare Increases}

The research suggests peak hour travel will be most highly demanded when gas prices go up. If levels of service are maximized during these times and demand exceeds what can be accommodated, a peak service ridership surcharge could be enacted to add revenues, encourage passengers to make off-peak trips if possible and prevent a universal fare increase that may deter off-peak usage. Fare increases in any event will negatively impact ridership, so the peak hour definition may be one way to mitigate some of the loss of ridership.

\section{Long-term Strategies}

Long-term actions are those that best maximize the ridership potential from high gas prices over a year or longer and help stabilize budgetary impacts from the cost of fueling the fleet of vehicles that provide service.

\section{Flexing Funds Between Capital and Operating Needs}

Until the authorization of the most recent federal funding bill, MAP-21, utilizing federal funds interchangeably between capital and operating needs was limited. MAP-21 includes new rules on use of urban formula 5307 funds, which allow for the following:

- Transit systems in urbanized areas over 200,000 can use their formula funding for operating expenses if they operate no more than 100 buses

- Systems operating between 76 and 100 buses in fixed route service during peak service hours may use up to 50 percent of their of funding for operating expenses

- Systems operating 75 or fewer buses in fixed route service during peak service hours may use up to 75 percent of their funding for operating expenses. 


\section{Effectively Managing Consumer Fuel Price Driven Transit Demand}

Additionally, the Consolidated and Further Continuing Appropriations Act, 2012 (Pub. L. 112-055) established that the Federal Transit Administration (FTA) could treat fuel costs for vehicle operations, including utility costs for the propulsion of electrical vehicles, as a capital maintenance item for grants. ${ }^{75}$

The flexibility allowed by these new rules gives transit agencies that are fully recapitalized the opportunity to shift some previously ineligible funds into activities that could help sustain operations. The risk is that, with such a shift, the transit agency might not have enough funds to purchase new vehicles or other capital facilities or equipment necessary to provide a quality service in the long run.

\section{Fuel Contracts}

Transit operators can perform a risk assessment to determine what type of fueling arrangement best serves their needs. The tradeoffs in these arrangements are typically predictability of pricing and the amount of risk involved.

Contract defined fixed-pricing provides for the greatest amount of predictability for budgetary reasons but is highly inflexible. The transit operator could bid out the cost for fueling services and only execute a contract if one or more bids come in at a predefined acceptable level. Due to the high amount of risk that could fall onto the bidders, there is a chance fewer proposals are submitted thereby limiting the effectiveness of competition. ${ }^{76}$

Fixed-price contracts with a defined adjustment formula are one way to share some of the risk associated with purchasing fuel while preserving some budgetary reliability. Formulas may be indexed to a source that tracks the industry, such as the 'Oil Price Information Service' and set with thresholds that triggers adjustments in the event prices increase or decrease to some extreme. ${ }^{77}$

Transit operators may have access to refueling at facilities operated by "sister" agencies with which they are affiliated. County or City governmental agencies are most likely to benefit from larger fuel contracts shared with public works and other fleet needs that generally result in lower unit costs for fuel. Transit authorities that don't have these resources may contract with local governments for access to their fueling sites. This may be of particular relevance for alternative fuels such as bio-diesel or natural gas powered vehicles which require expensive fueling facilities. There is a cost savings often realized with these arrangements though there might be an increased administrative requirement for tracking usage. ${ }^{78}$

Direct cost reimbursement treats fuel prices as a pass through cost. The current price of gasoline in the marketplace is paid on a fixed schedule by the transit agency. These arrangements are risky for the agency as fuel prices may increase and are coupled with little or no budgetary predictability. When considering how to provide transit in times of high gas prices, this may be the least desirable option.

These same methods for fuel purchases can also extend into service contracted by the transit agency. A comprehensive risk assessment as part of the overall budget process can balance the appetite for risk along with defining optimum fuel price targets so that high gas prices will not hinder the ability for an agency to provide service. 


\section{Effectively Managing Consumer Fuel Price Driven Transit Demand}

\section{Alternative Fuel and Propulsion Vehicles}

The second highest rated response in the Florida transit operator survey question regarding the reason for why agencies purchase alternative fuel and propulsion vehicles was to reduce expenditures on fuel costs. Conversion of all or a portion of a fleet into any number of alternative fuels can be an effective way to lower operating cost, shielding an operator from the volatile cost of gasoline or diesel. Prior to such a move, a great deal of background research should be done to determine the long-term viability of the alternative fuel, its availability and access, any training that might be required for existing staff, as well as costing any capital investments such as a fueling facility.

\section{Service Optimization}

Short-term service optimization is an activity to address current service shortfalls in response to gas prices, whereas planning for the long-term emphasizes structural changes to the transit network. Optimizing service in the era of high gas prices would focus on development of premium transit options; such as BRT or express service. This would include any efforts to make the bus system more attractive to discretionary riders through infrastructure and technology investments.

Some agencies also include factors for gas prices within their long range transit demand models, with different factors included at multiple price points for gas prices. These forecasts could warrant different service levels and modes. This may be particularly useful when resources are available to expand service, as discretionary markets may be the only ones where significant growth could occur. 


\section{ENDNOTES}

${ }^{5}$ Center for Neighborhood Technology. "Housing and Transportation Affordability Index", Accessed January $13^{\text {th }}, 2013$ from http://htaindex.cnt.org/faq.php.

${ }^{6}$ Federal Highway Administration, Livability Initiative, Transportation and Housing Costs. Accessed April 30 ${ }^{\text {th }}, 2013$ from http://www.fhwa.dot.gov/livability/fact sheets/transandhousing.cfm.

${ }^{7}$ Bureau of Labor Statistics. Consumer Price Index for "Gasoline - All Types", Accessed March $22^{\text {nd }}, 2013$ from http://data.bls.gov/cgi-bin/surveymost.

${ }^{8}$ U.S. Department of Energy, Independent Statistics and Analysis. Accessed February $11^{\text {th }}$, 2013 from www.eia.gov/todayinenergy/detail.cfm?id=9831.

${ }^{9}$ Federal Highway Administration Statistics. Accessed January 19 ${ }^{\text {th }}, 2013$ from http://www.fhwa.dot.gov/policyinformation/travel/tvt/history/.

${ }_{10}$ Federal Highway Administration Statistics through 2011, including the 50 states and District of Columbia.

Accessed February $11^{\text {th }}, 2013$ from http://www.fhwa.dot.gov/policyinformation/statistics/2011/vm202.cfm.

${ }^{11}$ U.S. Department of Energy. "Historical Gas Prices 1929-2011", Accessed September $13^{\text {th }}$, 2012 from http://www1.eere.energy.gov/vehiclesandfuels/facts/2012 fotw741.html.

12 Congressional Budget Office of the United States. "Effects of Gasoline Prices on Driving Behavior and Vehicle Markets", January 2008, p. 1.

13 Matthew Bomberg and Dr. Kara Kockelman (2011). "Traveler Response to the 2005 Gas Price Spike", Presented at the $86^{\text {th }}$ Annual Meeting of the Transportation Research Board, $\mathrm{p}$. 2.

14 Dan Brand (2009). "Impacts of Higher Fuel Costs", CRA International January 9, 2009. Accessed September $29^{\text {th }}, 2012$ from www.fhwa.dot.gov/policy/otps/innovation/issue1/impacts.htm.

${ }^{15}$ Dan Brand (2009). "Impacts of Higher Fuel Costs", CRA International January 9, 2009. Accessed September $29^{\text {th }}, 2012$ from www.fhwa.dot.gov/policy/otps/innovation/issue1/impacts.htm.

${ }^{16}$ Dan Brand (2009). "Impacts of Higher Fuel Costs", CRA International January 9, 2009. Accessed September $29^{\text {th }}, 2012$ from www.fhwa.dot.gov/policy/otps/innovation/issue1/impacts.htm.

17 Ashley Haire and Randy Machemehl (2010). "Regional and Modal Variability in Effects of Gasoline Prices on U.S. Transit Ridership", Journal of Transportation Research Board No. 2144, pp. 20-27.

${ }^{18}$ Victor Stover and C.H. Christine Bae (2011). "Impact of Gasoline Prices on Transit Ridership in Washington State", Journal of the Transportation Research Board, No. 2217, pp. 11-18.

19 Jeremy Mattson (2008). "Effects of Rising Gas Prices on Bus Ridership for Small Urban and Rural Transit Systems", Upper Great Plains Transportation Institute, June 2008, p. 22.

20 Todd Litman (2012). "Understanding Transport Demands and Elasticities. How Prices and Other Factors Affect Travel Behavior", Victoria Transport Policy Institute, pp. 44-59.

${ }^{21}$ George Wang and David Skinner (1984). "The impact of fare and gasoline price changes on monthly transit ridership: Empirical evidence from seven U.S. transit authorities", Transportation Research Part B: Methodological, Volume 18, Issue 1, February 1984, pp. 29-41.

22 Todd Litman (2012). "Understanding Transport Demands and Elasticities. How Prices and Other Factors Affect Travel Behavior", Victoria Transport Policy Institute, pp. 44-59. 
23 Todd Litman (2012). "Understanding Transport Demands and Elasticities. How Prices and Other Factors Affect Travel Behavior", Victoria Transport Policy Institute, pp. 44-59.

${ }^{24}$ Graham Currie and Justin Phung (2007). "Transit Ridership, Auto Gas Prices, and World Events, New Drivers of Change?", Journal of the Transportation Research Board, No. 1992, pp. 3-10.

${ }^{25}$ Cynthia Chen, Don Varley and Jason Chen (2011). "What Affects Transit Ridership? A Dynamic Analysis involving Multiple Factors, Lags and Asymmetric Behavior", Journal of Urban Studies 2011, No. 48, pp. 1893-1908.

26 Johan Holmgren (2007) "Meta-analysis of public transport demand", Transportation Research Part A, No 41, pp. 1021-1035.

${ }^{27}$ Geoffrey Rose (1986). "Transit Passenger Response: Short- and Long-Term Elasticities Using Time Series Analysis", Transportation, No. 13, pp. 131-141.

28 Ozlem Yanmaz-Tuzel and Kaan Ozbay (2010). "Impacts of Gasoline Prices on New Jersey Transit Ridership", Journal of the Transportation Research Board, No. 2144, pp. 52-61.

29 Ozlem Yanmaz-Tuzel and Kaan Ozbay (2010). "Impacts of Gasoline Prices on New Jersey Transit Ridership", Journal of the Transportation Research Board, No. 2144, pp. 52-61.

30 Jeff Deutsch (2011). "New Jersey Public Transportation Ridership: The Effect of Fuel Prices, Infrastructure and Socioeconomic Factors", May 2011, pp. 1-16. Accessed on February $7^{\text {th }}, 2013$ from http://business.pages.tcnj.edu/files/2011/07/Deutsch.thesis.pdf. ${ }^{31}$ Cynthia Chen, Don Varley and Jason Chen (2011). "What Affects Transit Ridership? A Dynamic Analysis involving Multiple Factors, Lags and Asymmetric Behavior", Journal of Urban Studies 2011, No. 48, pp. 1893-1908.

32 Graham Currie and Justin Phung (2007). "Transit Ridership, Auto Gas Prices, and World Events, New Drivers of Change?", Journal of the Transportation Research Board, No. 1992, pp. 3-10.

33 Jeremy Mattson (2008). "Effects of Rising Gas Prices on Bus Ridership for Small Urban and Rural Transit Systems", Upper Great Plains Transportation Institute, June 2008, p. 22.

34 Todd Litman (2012). "Understanding Transport Demands and Elasticities. How Prices and Other Factors Affect Travel Behavior", Victoria Transport Policy Institute, pp. 44-59.

${ }^{35}$ Cynthia Chen, Don Varley and Jason Chen (2011). "What Affects Transit Ridership? A Dynamic Analysis involving Multiple Factors, Lags and Asymmetric Behavior", Journal of Urban Studies 2011, No. 48, pp. 1893-1908.

36 Donald Maley and Rachel Weinberger (2009). "Rising Gas Price and Transit Ridership, Case Study of Philadelphia, PA", Journal of the Transportation Research Board, No. 2139, pp. $183-188$.

${ }^{37}$ Todd Litman (2012). "Understanding Transport Demands and Elasticities. How Prices and Other Factors Affect Travel Behavior", Victoria Transport Policy Institute, pp. 44-59.

38 Todd Litman (2012). "Understanding Transport Demands and Elasticities. How Prices and Other Factors Affect Travel Behavior", Victoria Transport Policy Institute, pp. 44-59.

${ }^{39}$ Congressional Budget Office of the United States. "Effects of Gasoline Prices on Driving Behavior and Vehicle Markets", January 2008, p. 1.

${ }^{40}$ Karl Storchmann (2001). "The impact of fuel taxes on public transport, an empirical assessment for Germany", Transport Policy, No. 8, pp. 19-28.

${ }^{41}$ Graham Currie and Justin Phung (2007). "Transit Ridership, Auto Gas Prices, and World Events, New Drivers of Change?", Journal of the Transportation Research Board, No. 1992, pp. 3-10.

42 Bradley Lane (2010). "Effect of Fuel Price Increases on U.S. Light Rail Ridership, 20022008", Transportation Research Circular, July 2010, Presented to the Joint International Light Rail Conference, April 2009, pp. 63-76. 
43 Jeff Deutsch (2011)."New Jersey Public Transportation Ridership: The Effect of Fuel Prices, Infrastructure and Socioeconomic Factors", May 2011, pp. 1-16. Accessed on February $7^{\text {th }}, 2013$ from http://business.pages.tcnj.edu/files/2011/07/Deutsch.thesis.pdf. ${ }^{44}$ Ozlem Yanmaz-Tuzel and Kaan Ozbay (2010). "Impacts of Gasoline Prices on New Jersey Transit Ridership", Journal of the Transportation Research Board, No. 2144, pp. 52-61.

45 Geoffrey Morrison, Micah Fuller and Chris Knittel (2011). "Price Elasticities off Gasoline Demand: A State Level Analysis", Institute of Transportation Studies, University of California at Davis. Accessed on September 12, 2012 from http://steps.ucdavis.edu/Events/2011-steps-symposium/posters/Morrison\%20\%20Elasticity\%20Poster\%20-\%20Jan2011.pdf.

${ }^{46}$ Ashley Haire and Randy Machemehl (2010). "Regional and Modal Variability in Effects of Gasoline Prices on U.S. Transit Ridership", Journal of Transportation Research Board No. 2144, pp. 20-27.

47 Todd Litman (2012). "Understanding Transport Demands and Elasticities. How Prices and Other Factors Affect Travel Behavior", Victoria Transport Policy Institute, pp. 44-59.

48 Matthew Bomberg and Dr. Kara Kockelman (2011). "Traveler Response to the 2005 Gas Price Spike", Presented at the $86^{\text {th }}$ Annual Meeting of the Transportation Research Board, $\mathrm{p}$. 2.

49 Jeremy Mattson (2008). "Effects of Rising Gas Prices on Bus Ridership for Small Urban and Rural Transit Systems", Upper Great Plains Transportation Institute, June 2008, p. 22.

50 Charlotte Albright (2012). "Gas Prices Force More People to Take Rural Transit" From a quote by Jill Hough of the Upper Great Plains Transportation Institute, March 15 ${ }^{\text {th }}, 2012$. Accessed on September $15^{\text {th }}, 2012$ from www.npr.org .

${ }^{51}$ Elizabeth Kneebone and Emily Garr (2010). "The Suburbanization of Poverty: Trends in Metropolitan America, 2000 to 2008", Metropolitan Policy Program at the Brookings Institute, January 2010, p.1-22. Accessed on October $19^{\text {th }}, 2012$ from www.brookings.edu/metro.

52 Aaron Golub (2010). "Welfare and Equity Impacts of Gasoline Price Changes under Different Public Transportation Service Levels", Journal of Public Transportation, Volume 13, No. 3, pp. 1-20.

${ }^{53}$ Steve Sexton, JunJie Wu and David Zilberman (2012). "How High Gas Prices Triggered the Housing Crisis: Theory and Empirical Evidence", Center for Energy and Environmental Economics at the University of California. Accessed on September $13^{\text {th }}, 2012$ from http://www.uce3.berkeley.edu/WP 034.pdf.

${ }^{54}$ Raven Molloy and Hui Shan. "The Post-Foreclosure Experience of U.S. Households in the Current Housing Market Downturn", Federal Reserve Board of San Francisco, pp. 1-37. Accessed on September $13^{\text {th }}, 2012$ from http://www.frbsf.org/community/conferences/2011ResearchConference/docs/3a-molloyshan.pdf.

55 Katie Murdoch (2012). "Mass transit picks up riders as gas prices rise", The Everett Herald 4/9/2012. Accessed from www.heraldnet.com/article/20120409/NEWS01/704099963.

${ }^{56}$ Danny Valentine (2012). "Pinellas and Hillsborough bus ridership at all-time highs, thanks to economy, gas prices, tourism", Tampa Bay Times April 10, 2012. Accessed from http://www.tampabay.com/news/transportation/pinellas-and-hillsborough-bus-ridership-atall-time-highs-thanks-to/1224164.

57 Ashley Torres (2011). "Rising gas price, job growth spurring Tri-Rail ridership gains", Miami Today News April $7^{\text {th }}, 2011$. Accessed from http://miamitodaynews.com/news/110407/story2.shtml. 
58 Michael Cooper (2009). "Transit Use Hit Five-Decade High in 2008 as Gas Prices Rose", New York Times, March 9, 2009. Accessed November 30 ${ }^{\text {th }}, 2012$ from www.nytimes.com/2009/03/09/us/09transit.html.

${ }^{59}$ Ray LaHood (2012). "Transit getting more Americans where they need to go", The Official Blog of the U.S. Secretary of Transportation, April $8^{\text {th }}$ 2012. Accessed September $18^{\text {th, }} 2012$ from http://fastlane.dot.gov/2012/04/february-transit-ridership.html\#.UXFZVKI3te9.

60 Michael Lindenberger (2012). "Gas prices and ridership: At DART, the correlation is fuzzy", Dallas Morning News Transportation Blog, May $15^{\text {th }}, 2012$. Accessed September $13^{\text {th }}$, 2012 from http://transportationblog.dallasnews.com/2012/05/of-gas-prices-and-ridershipat-dart-the-correlation-is-fuzzy.html/.

${ }_{61}^{61}$ Ibid.

62 Steve Hargreaves (2012). "Rising gas prices aren't as bad as you think", CNNmoney, March 21, 2012. Accessed September $13^{\text {th }}, 2012$ from http://money.cnn.com/2012/03/21/news/economy/gas-prices-impact/index.htm. ${ }_{63}$ Christopher Blanchard (2009). "The Impact of Rising Gasoline Prices on U.S. Public Transit Ridership", Duke University. Accessed on January $8^{\text {th }}, 2013$ from http://dukespace.lib.duke.edu/dspace/handle/10161/1379.

${ }^{64}$ Presentation by Office of Long Range Planning, WMATA "Short-Term Ridership Forecasting Model (Version 3.0)", January 2009.

${ }^{65}$ Christopher Blanchard (2009). "The Impact of Rising Gasoline Prices on U.S. Public

Transit Ridership", Duke University. Accessed on January 8 ${ }^{\text {th }}, 2013$ from

http://dukespace.lib.duke.edu/dspace/handle/10161/1379.

${ }^{66}$ Cynthia Chen, Don Varley and Jason Chen (2011). "What Affects Transit Ridership? A Dynamic Analysis involving Multiple Factors, Lags and Asymmetric Behavior", Journal of Urban Studies 2011, No. 48, pp. 1893-1908.

67 Jeremy Mattson (2008). "Effects of Rising Gas Prices on Bus Ridership for Small Urban and Rural Transit Systems", Upper Great Plains Transportation Institute, June 2008, p. 22. ${ }^{68}$ American Public Transportation Association (APTA) (2008). "How Transit Agencies are Addressing the Impact of Fuel Price and Ridership Increases", September 22, 2008.

${ }^{69}$ American Public Transportation Association (APTA) (2008). "How Transit Agencies are Addressing the Impact of Fuel Price and Ridership Increases", September 22, 2008.

${ }^{70}$ Alasdair Cain and Jennifer Flynn. "Quantifying the Importance of Image and Perception to Bus Rapid Transit", National Bus Rapid Transit Institute. Accessed on February $12^{\text {th }}, 2013$ from http://www.nbrti.org/docs/pdf/NBRTI\%20-\%20BRT\%20Image\%20Study\%20$\% 20$ March\%202009 Final\%20Draft highres.pdf.

${ }^{71}$ Federal Transit Administration, Urban Circulator Initiative. Accessed on February $12^{\text {th }}$ 2013 from http://www.fta.dot.gov/about/about FTA 11006.html.

${ }^{72}$ Accessed on September $22^{\text {nd }}, 2013$ from http://www.dccirculator.com/.

73 Yonah Freemark (2009). "DOT to Award \$280 Million in Inner-City Circulator Grants". Accessed on February 22 ${ }^{\text {nd }}, 2013$ from http://www.thetransportpolitic.com/2009/12/02/dotto-award-280-million-in-inner-city-circulator-grants/.

742009 National Household Travel Survey, http://nhts.ornl.gov/.

75 Federal Transit Administration. "Section 5307 Urbanized Area Formula Program: Allocation of Funding Caps for Treating Fuel and Electric Utility Costs for Vehicle Propulsion as a Capital Maintenance Expense", April 12 ${ }^{\text {th }}, 2012$ Federal Register.

${ }^{76}$ Alan M. Voorhees Transportation Center, Edward J Bloustein School of Planning and Public Policy and Rutgers University (2004). "Fuel Price Adjustment Techniques: A Review of Industry Practice". Accessed on September $12^{\text {th }}, 2012$ from http://policy.rutgers.edu/vtc/documents/InstAnal.FuelPricing.pdf. 


\section{Effectively Managing Consumer Fuel Price Driven Transit Demand}

77 Alan M. Voorhees Transportation Center, Edward J Bloustein School of Planning and Public Policy and Rutgers University (2004). "Fuel Price Adjustment Techniques: A Review of Industry Practice". Accessed on September $12^{\text {th }}, 2012$ from

http://policy.rutgers.edu/vtc/documents/InstAnal.FuelPricing.pdf

${ }^{78}$ Alan M. Voorhees Transportation Center, Edward J Bloustein School of Planning and Public Policy and Rutgers University (2004). "Fuel Price Adjustment Techniques: A Review of Industry Practice". Accessed on September $12^{\text {th }}, 2012$ from

http://policy.rutgers.edu/vtc/documents/InstAnal.FuelPricing.pdf 
